\title{
1 Trophic niche of the invasive gregarious species Crepidula 2 fornicata, in relation to ontogenic changes
}

3

\author{
Thibault Androuin ${ }^{1,2}$, Stanislas F. Dubois ${ }^{2}$, Cédric Hubas ${ }^{3}$, Gwendoline Lefebvre ${ }^{4}$, Fabienne Le Grand ${ }^{4}$, \\ Gauthier Schaal ${ }^{4}$, Antoine Carlier ${ }^{2}$. \\ ${ }^{1}$ ISMER, UQAR, Rimouski, Canada \\ ${ }^{2}$ IFREMER, DYNECO-LEBCO, Technopole Brest-Iroise, CS10070, Plouzané, France \\ ${ }^{3}$ UMR BOREA, Muséum National d'Histoire Naturelle, Concarneau, France \\ ${ }^{4}$ UMR CNRS 6539, LEMAR-IUEM-UBO, Plouzané, France
}

\begin{abstract}
Crepidula fornicata is a common and widespread invasive gregarious species along the European coast. Among its life-history traits, well documented ontogenic changes in behavior (i.e., motile male to sessile female) suggest a potential shift in feeding strategy across its life stages. Considering the ecological significance of this species in colonized areas, understanding how conspecifics share the trophic resource is crucial. Using fatty acids (FA) and stable isotopes (SI) as complementary trophic markers, we conducted a field survey between late winter and spring to investigate the trophic niche of three ontogenic stages of $C$. fornicata that bear different sexual (male/female) and motility (motile/sessile) traits. Potential trophic sources were characterized by their pigment, FA and SI compositions and showed well discriminated compositions over the studied period. We showed that the biofilm covering $C$. fornicata shells harbored a higher biomass of primary producers (i.e., chlorophytes and diatoms) than the surrounding sediment. Over the studied period, we observed a covariation between the three ontogenic stages for both FA and SI compositions which suggest that the trophic niche of $C$. fornicata does not change significantly across its benthic life. During periods of low food availability, slipper limpets displayed an opportunistic suspension-feeding behaviour, relying on both fresh and detrital organic matter, likely coming from superficial sedimentary organic matter. However, during high food availability (i.e., spring phytoplankton bloom), all ontogenic stages largely benefited from this fresh supply of organic matter (pelagic diatoms in this case). The three ontogenic stages showed consistent differences in FA composition, and to a lesser extent in SI composition. These differences persist over time, as they originate from ontogenic physiological changes (differential growth rates, metabolic rate or gametogenesis) rather than diet discrepancies. This study revealed that multiple trophic markers allow high complementary to characterize organic matter as well as food partitioning between conspecific organisms.
\end{abstract}

Key words: Crepidula fornicata, trophic niche, ontogenic shift, fatty acids, stable isotopes, pigments, Bay of Brest Corresponding authors: thibault.androuin01@gmail.com 


\section{Introduction}

The slipper limpet Crepidula fornicata is a non-indigenous and invasive gastropod originating from the East coast of the US (Blanchard, 1997). This species extensively colonized shallow soft bottom habitats of European coasts, from Norway to the Mediterranean Sea (Blanchard, 1997). Because of its introduction in many parts of the world and its potential cascading effect on food web functioning (Arbach Leloup et al., 2008; Chauvaud et al., 2000; Cugier et al., 2010), several studies have closely investigated its diet and inferred potential trophic overlap with co-occurring benthic species (Blanchard et al., 2008; P Decottignies et al., 2007; Priscilla Decottignies et al., 2007; Lefebvre et al., 2009; Riera, 2007; Riera et al., 2002). $C$. fornicata is overall considered has an opportunistic suspension-feeder, able to feed on a large array of trophic sources (e.g., phytoplankton, microphytobenthos, macroalgae, bacteria), depending on their availability. Based on stable isotope ratios, it has been hypothesised a potentially large contribution of microphytobenthos, and more specifically benthic diatoms, in the diet of $C$. fornicata (P Decottignies et al., 2007; Guérin, 2004; Lefebvre et al., 2009; Riera, 2007). However, the unexpected presence of inorganic carbonates in C. fornicata soft tissues have led to overestimate $\delta^{13} \mathrm{C}$ ratios in the consumer and then to overestimate the trophic role of microphytobenthos (Androuin et al., 2019).

C. fornicata is a hermaphroditic gregarious species, which begins its benthic life as a low-motile male and become a sessile female. Sessile adults form stacks of several non-moving individuals, while juveniles and small males $(\sim 10 \mathrm{~mm})$ are motile (Coe, 1936). Adult females are suspension-feeders, but contrary to bivalves, they lack labial palp and showed no anatomical or functional potential for qualitative selection (Beninger et al., 2007). They form a food cord in a groove at the distal end of their gill filaments and ultimately catch this cord with their radula before ingesting it (Shumway et al., 2014). For the related species Crepidula fecunda, which exhibits ontogenic behavior changes comparable to those of $C$. fornicata, it has been demonstrated that newly settled individuals first adopt a grazing feeding mechanism and gradually shift to a suspension-feeding behaviour once their gill are fully developed (Montiel et al., 2005). Young individuals are able to use both feeding mechanisms (i.e., grazing and suspension-feeding) during the motile phase of their life cycle (size $<28 \mathrm{~mm}$ ), whereas females are exclusive suspension-feeders (Chaparro et al., 2002; Navarro and Chaparro, 2002). Such observations have also been suggested for C. fornicata but without further behavioral evidence nor quantitative measurements (Breton and Huriez, 2010; Yee and Padilla, 2015). Since $C$. fornicata often occurs in large densities (up to 2000 ind. $\mathrm{m}^{-2}$ ) on the seafloor with all ontogenic stages grouped in stacks (Guérin, 2004; Martin et al., 2006), one can expect strong intraspecific interactions for food. These interactions could be either facilitative or competitive depending on ontogenic feeding ecology. While purely suspension-feeding slipper limpets should compete for food among ontogenic stages, recent works suggested that younger individuals may be facilitated by adults, both via a higher substrate availability (de Montaudouin and Accolla, 2018) and through the grazing of microphytobenthic microalgae colonizing adult shells (Androuin et al., 2018). Given that $C$. fornicata often proliferates on muddy and turbid habitats with high suspended inorganic load, grazing behavior of motile males could also prevent the overloading of their digestive tract with inert matter of low nutritional quality (Navarro and Chaparro, 2002).

Different trophic markers have long been used to investigate the trophic niche of marine benthic invertebrates (e.g., Blanchet-Aurigny et al., 2015; Cresson et al., 2016; Dubois and Colombo, 2014) and to describe the origin of assimilated particulate organic matter (hereafter OM) (Ke et al., 2017; Lavaud et al., 2018; Liénart et al., 2017). As mentioned earlier, carbon and nitrogen stable isotopes (SI) are broadly used used to infer trophic niche of consumers (Fry and Sherr, 1984; Layman et al., 2012). Classically, nitrogen isotope ratio informs about the trophic position of a species and carbon isotope ratio reflects the origin of assimilated food sources (e.g., continental vs. oceanic). In coastal ecosystems, the diet of most of benthic primary consumers is composed of a mixture of OM from various origins (phytoplankton, macroalgae, continental detritus, zooplankton, etc) which are often difficult to disentangle with isotopes of only two elements, namely carbon and nitrogen. This diversity of food sources implies that complementary trophic markers are relevant to complement SI intel (Majdi et al., 2018). For instance, pigment analyses have been widely used to study community composition of microscopic primary producers in the water column or in the sediment, since some pigments are specific of clades of algae (Brotas and Plante-Cuny, 2003; Roy et al., 2011). To a lesser extent, fatty acid compositions can be also specific of group of organisms, such as diatoms, bacteria, copepods or vascular plants, (Dalsgaard et al., 2003; Kelly and Scheibling, 2012). Recently, the combined use of SI, FA and pigments improved our understanding of trophic pathways from the sources of particulate OM to benthic primary consumers (Lavaud et al., 2018; Majdi et al., 2018). 
In this study, we investigated the trophic niche of $C$. fornicata and quantified intra-specific diet shift associated with ontogenic behavior changes (i.e., motile male to sessile female). For this purpose, we conducted a field survey and characterized potential OM sources by their SI, FA and pigments compositions and inferred their assimilation in C. fornicata tissues using both SI and FA trophic markers. Based on previous experimental study in stimulated microphytobenthic biofilm in C. fornicata beds (Androuin et al., 2018), we expect ontogenic trophic shift to happen within stacks, with a higher contribution of biofilm to motile males than to sessile males and females.

\section{Materials and methods}

\subsection{Sampling strategy}

The bay of Brest (Brittany, France) is a $180 \mathrm{~km}^{2}$ semi-enclosed marine ecosystem. The sampling site is located near the Elorn estuary $\left(48^{\circ} 23^{\prime} \mathrm{N}, 4^{\circ} 23^{\prime}\right.$, average depth: $\left.10 \mathrm{~m}\right)$ in a dense $C$. fornicata beds $\left(\sim 2000\right.$ ind. $\mathrm{m}^{-2}$ ) (Guérin, 2004). Potential OM sources and $C$. fornicata individuals were collected by SCUBA divers at five sampling dates $\left(\mathrm{S} 1=26^{\text {th }}\right.$ February, $\mathrm{S} 2=21^{\text {th }}$ March, S3 $=28^{\text {th }}$ March, $\mathrm{S} 4=12^{\text {th }}$ April and $\mathrm{S} 5=14^{\text {th }}$ June) around mid and flood tide to ensure homogeneous mixing between estuarine and oceanic water. The late winter - spring period was chosen to encompass a period with potentially contrasted OM sources availability (e.g., spring blooms) (Figure 1).

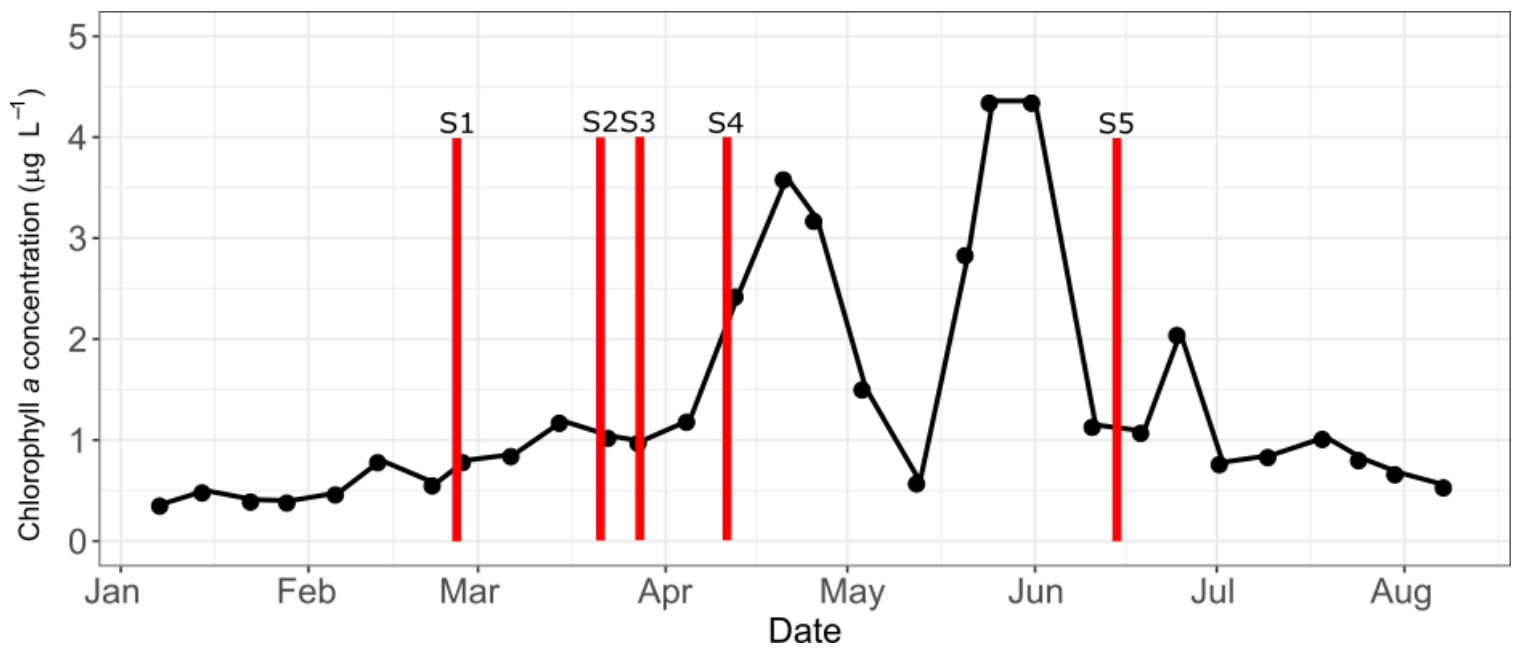

Figure 1: Sampling dates (S1 to S5) at the study site superimposed with weekly chlorophyll $a$ concentration at the entrance of the bay of Brest in 2018 (data from the French Coastal Monitoring Network SOMLIT; http://somlit.epoc.u-bordeaux1.fr/fr/).

Suspended particulate organic matter (SPOM) was sampled using two 8-litersNiskin bottles at 50 $\mathrm{cm}$ above the sediment-water interface, immediately filtered on board onto a $200 \mu \mathrm{m}$ nylon mesh to remove large zooplankton and particles. In the laboratory, between 1 and $1.5 \mathrm{~L}$ was filtered on pre-combusted $\left(450^{\circ} \mathrm{C}\right.$ for 5 hours) GF/F filters $(0.7 \mu \mathrm{m})$. Three replicates for each of the three analyses (SI, FA and pigment) were obtained. Superficial sedimentary organic matter (SSOM) was sampled from three cores of $15 \mathrm{~cm}$ diameter and $15 \mathrm{~cm}$ depth. In the laboratory, the sediment-water interface was re-suspended by flushing seawater with a $30 \mathrm{ml}$ syringe following a standardized process: $60 \mathrm{ml}$ of SSOM was pre-filtered on a $200 \mu \mathrm{m}$ nylon mesh to being consistent with SPOM samples and filtered on pre-combusted $\left(450^{\circ} \mathrm{C}\right.$ during 5 hours $) \mathrm{GF} / \mathrm{F}$ filters $(0.7 \mu \mathrm{m})$. Three replicates for each of the three analyses were obtained. Biofilm from one $C$. fornicata stacks was scrapped off using a toothbrush and suspended in $600 \mathrm{ml}$ of filtered seawater $(0.7 \mu \mathrm{m}) .200 \mathrm{ml}$ of the suspended solution was filtered on pre-combusted $\left(450^{\circ} \mathrm{C}\right.$ for 5 hours) on GF/F filters $(0.7 \mu \mathrm{m})$. Three replicates for each of the three analyses were obtained. Filters for FA analysis were put in glass tubes containing $6 \mathrm{ml}$ of chloroform-methanol $(2: 1, \mathrm{v}: \mathrm{v})$ solution and stored at $-80^{\circ} \mathrm{C}$ before analysis, whereas filters for pigment and SI analysis were immediately stored at $-80^{\circ} \mathrm{C}$.

Females of $C$. fornicata were sampled at the bottom of the stacks (mean shell length $33 \pm 6 \mathrm{~mm}$ ), attached to a dead $C$. fornicata shell. Sessile and motile males were sampled if they had a penis and a mean 
shell length of $20 \pm 8 \mathrm{~mm}$ and $10 \pm 1 \mathrm{~mm}$, respectively. We used the digestive gland as a relevant trophic integrator tissue because it has a higher turnover rate than muscle tissue and is an energy storage organ enriched in lipids (McCutchan et al., 2003; Vander Zanden et al., 2015). However, since digestive gland and gonad are fused in a single organ in C. fornicata, we analysed both tissues together for sessile males and females. Because gonads are comparatively small in motile males, the whole body was used to ensure sufficient lipid concentration. At each date and for each ontogenic stage, both stable isotope (SI) and fatty acid (FA) analyses of $C$. fornicata were performed on subsamples originating from the same tissue sample.

\subsection{Pigment analysis}

The photosynthetic communities of SSOM, biofilm and SPOM have been analyzed by the quantification of pigments by High Performance Liquid Chromatography (HPLC) according to Brotas and Plante-Cuny (2003). Filters were crushed and extracted in $3 \mathrm{ml}$ of $95 \%$ cold buffered methanol (2\% ammonium acetate) for $20 \mathrm{~min}$ at $-20^{\circ} \mathrm{C}$ in the dark. Samples were centrifugated for 3 minutes at $3000 \mathrm{~g}$ after the extraction period. Extracts were then filtered with Whatman membrane filters $(0.2 \mathrm{~mm})$ immediately before HPLC analysis. Pigment extracts were analysed using an Agilent 1260 Infinity HPLC composed of a quaternary pump (VL 400 bar), a UV-VIS photodiode array detector (DAD $1260 \mathrm{VL}, 190-950 \mathrm{~nm}$ ), and a $100 \mu \mathrm{l}$ sample manual injection loop (overfilled with $250 \mu \mathrm{l}$ ). Chromatographic separation was carried out using a C18 column for reverse phase chromatography (Supelcosil, $25 \mathrm{~cm}$ long, $4.6 \mathrm{~mm}$ inner diameter). The solvents used were A: $0.5 \mathrm{M}$ ammonium acetate in methanol and water $(85: 15, \mathrm{v}: \mathrm{v})$, B: acetonitrile and water (90:10, v:v), and C: $100 \%$ ethyl acetate. The solvent gradient followed the Brotas and Plante-Cuny method (2003), with a flow rate of $0.5 \mathrm{~mL} \mathrm{~min}^{-1}$. Identification and calibration of the HPLC peaks were performed with chlorophyll $a, \beta \beta$-carotene, chlorophyll $\mathrm{c} 2$, diatoxanthin, diadinoxanthin and fucoxanthin standards. All peaks detected were identified by their absorption spectra and relative retention times using the Open Lab CDS software (ChemStation Edition for LC/MS Systems, Agilent Technologies). Quantification was performed by repeated injections of standards over a range of dilutions to establish a standard curve of concentrations. Pigment percentages were expressed relatively to the surface/volume sampled $\left(\mu \mathrm{g} . \mathrm{cm}^{-2}\right.$ for biofilm and SSOM, and $\mu \mathrm{g} \mathrm{L}^{-1}$ for SPOM). We measured the mean surface of three stacks of $C$. fornicata to standardize surfaces.

\subsection{Stable isotope analysis}

$\delta^{15} \mathrm{~N}$ and $\delta^{13} \mathrm{C}$ analyses were carried out independently for both OM sources and C. fornicata tissues. For OM sources, filters were freeze-dried and split in two equal parts. Half of the filter was scrapped off and weighed in tin capsules for $\delta^{15} \mathrm{~N}$ analysis. The second half was decarbonated using acid-flume $(10 \mathrm{~N}$ hydrochloric acid solution) for 7 hours (Lorrain et al., 2003), dried at $40^{\circ} \mathrm{C}$ for $12 \mathrm{~h}$, scrapped off and weighed in tin capsules for $\delta^{13} \mathrm{C}$ analysis. C. fornicata samples were freeze-dried and ground into homogenous powder using a mortar and pestle. Approximately $400 \mu \mathrm{g}$ of powder was weighed in tin capsules for $\delta^{15} \mathrm{~N}$ analysis. Because both lipids content and inorganic carbonates can influence $\delta^{13} \mathrm{C}$ (Androuin et al., 2019; McCutchan et al., 2003), approximately $400 \mu \mathrm{g}$ of powder was added to $1 \mathrm{ml}$ of cyclohexane in Eppendorf tubes. Tubes were vortexed and centrifuged at $3000 \mathrm{~g}$ during $5 \mathrm{~min}$. The supernatant was discarded, and the tubes dried at $40^{\circ} \mathrm{C}$ during $12 \mathrm{~h}$. If the supernatant remained coloured, the sample was re-processed. Lipid-free tissues were then weighed in silver capsules and in-cup decarbonated using $1 \mathrm{~N} \mathrm{HCl}$. Each capsule was visually checked, dried at $40^{\circ} \mathrm{C}$ during $1 \mathrm{~h}$, and sealed. Samples were analysed for $\delta^{15} \mathrm{~N}$ and $\delta^{13} \mathrm{C}$ by continuous flow on a Thermo Scientific Flash EA 2000 elemental analyser coupled to a Delta V Plus mass spectrometer at the Pôle de Spectrométrie Océan (PSO, Plouzané, France). Results are expressed in standard $\delta$ notation based on international standards (Vienna Pee Dee Belemnite for $\delta^{13} \mathrm{C}$ and atmospheric nitrogen for $\delta^{15} \mathrm{~N}$ ) following the equation:

$$
\left.\delta=[(\text { Rsample/Rstandard })-1] \times 10^{3} \text { (in \%o }\right) \text {, where } R \text { is }{ }^{13} \mathrm{C} /{ }^{12} \mathrm{C} \text { or }{ }^{15} \mathrm{~N} /{ }^{14} \mathrm{~N} .
$$

International isotopic standards of known $\delta^{15} \mathrm{~N}$ and $\delta^{13} \mathrm{C}$ values were used: IAEA-600 Caffeine, IAEA-CH6 Sucrose, IAEA-N-1 and IAEA-N-2 Ammonium Sulphate. The analytical precision was estimated using the standard deviation of an internal standard (Thermo Acetanilide, $n=8$ ), as $\pm 0.11 \%$ and $\pm 0.07 \%$ for $\delta^{13} \mathrm{C}$ and $\delta^{15} \mathrm{~N}$ values, respectively. 


\subsection{Fatty acids analysis}

Freeze-dried powder of C. fornicata was subsampled for FA analyses: between 2 and $20 \mathrm{mg}$ depending on ontogenic stages - were immediately put in glass tubes (previously heated for $6 \mathrm{~h}$ at $450^{\circ} \mathrm{C}$ ) containing $6 \mathrm{~mL}$ of a chloroform/methanol mixture (2:1, v:v), and extracted with a Dounce homogenizer. $\mathrm{OM}$ sources and $C$. fornicata samples were sonicated during $10 \mathrm{~min}$ and kept at $-20^{\circ} \mathrm{C}$ until further analysis. The total lipid fractions were analyzed in OM sources, whereas only the neutral lipids were analyzed in $C$. fornicata samples. The detailed analysis method for separation and methylation is detailed in Le Grand et al. (2014). Fatty acid methyl esters (FAME) were analyzed in a Varian CP 8400 gas chromatograph (GC) equipped with a split/splitless injector and a flame-ionization detector (FID). FAMEs were identified using two different capillary columns (ZBWAX $30 \mathrm{~m} \times 0.25 \mathrm{~mm}$ i.d., $0.25 \mu \mathrm{m}$ thickness, Phenomenex $®$; and ZB5HT $30 \mathrm{~m} \times 0.25 \mathrm{~mm}$ i.d., $0.25 \mu \mathrm{m}$ thickness, Phenomenex $\left.{ }^{\circledR}\right)$ by means of a standard 37 component FAME mix (Sigma Aldrich ${ }^{\circledR}$ ) and other known standard mixtures. FAs were expressed as the molar percentage of the total FA content.

\subsection{Statistical analyses}

Pigment and FA compositions of OM sources, and FA compositions of ontogenic stages of $C$. fornicata were represented using a non-metric multidimensional Scaling (n-MDS). Homogeneity of the data was tested using permutational analyses of multivariate dispersion (PERMDISP) (Anderson, 2001). Statistical analyses on OM sources (pigments and FA) and $C$. fornicata (FA) were conducted using a nonparametric distanced-based permutation multivariate analysis of variance (PERMANOVA) based on a BrayCurtis distance. Analyses were performed using two variables: OM sources or ontogenic stages (3 levels' factors) and sampling dates (5 levels' factor). Each date was considered independent due to the relative high turnover rate of both microorganisms found in the OM sources as well as the cells in the sampled tissues in C. fornicata. Following significant PERMANOVA results, post hoc tests were carried out using multiple pairwise comparisons with Bonferroni correction to identify differences among factors (Martinez Arbizu, 2017). However, the number of samples at each sampling date $(3<\mathrm{n}<5)$ was not sufficient to allow significant differences among the two factor levels in interaction, because of lack of statistical power when using Bonferroni correction in too many multiple comparisons. Therefore, post hoc comparisons of interaction term were not investigated. Finally, a SIMPER analysis was used to identify the FA explaining most of the dissimilarities between sampling dates and OM sources/ontogenic stages of $C$. fornicata.

Temporal variations and differences in SI ratios and pigment ratios/FA markers between OM sources/ontogenic stages of $C$. fornicata and sampling dates were assessed using two-way factorial analyses of variance (ANOVA). When significant, post hoc multiple comparisons were carried out using Tukey HSD. Normality and homogeneity of residuals were graphically assessed. Because concentrations in SPOM were not comparable with biofilm and SSOM (surface $v s$. volume), only SSOM and biofilm concentrations were compared together using the same procedure. Statistical analyses were performed in R version 3.3.0 (R Core Team, 2016) using packages 'vegan', 'plyr', 'FactoMiner', and 'ggplot'.

\section{Results}

\subsection{Organic matter sources}

\subsubsection{Pigments and fatty acids compositions}

Overall, OM sources were well discriminated by their pigment compositions (Figure 2a), and by their FA compositions (Figure 2b).

Pigment compositions significantly differed between OM sources and sampling dates $(p<0.001$ in both cases) and the interaction between the two factors was significant $(p<0.001)$. SIMPER analysis revealed that $80 \%$ of the variability was explained by 7 pigments (Table S1). The biofilm was characterized by higher percentages of chlorophyll $b$ and neoxanthin, together with one unknown pigment. SSOM was characterized by pheophytin $a$, pheophorbide $a$, and to a lesser extent lutein, whereas fucoxanthin and alloxanthin mainly discriminated SPOM. Temporal variations were mainly driven by a constant increase in both pheophorbide $a$ and pheophytin $a$ percentages for all OM sources. Fucoxanthin also showed an increase over time, except for SPOM and SSOM at S5 (Table S1). 

in both cases), and the two factors showed a significant interaction $(p<0.001)$. According to the SIMPER analysis, SSOM was characterized by higher percentages of 22:0, 16:1n-7, 18:1n-7 and a lower percentage of 16:0 (Table S2). The FA 18:0 and 20:4n-6 mostly discriminated biofilm whereas SPOM had higher percentages of 14:0 and 22:2n-6, and a lower percentage of 20:5n-3. In terms of temporal variations, both biofilm and SPOM showed similar decrease in saturated FA (i.e., 16:0 and 18:0) and increase in 16:1n-7 and 20:5n-3, especially between S4 and S5 (Table S2). SSOM exhibited less variable FA composition over time.
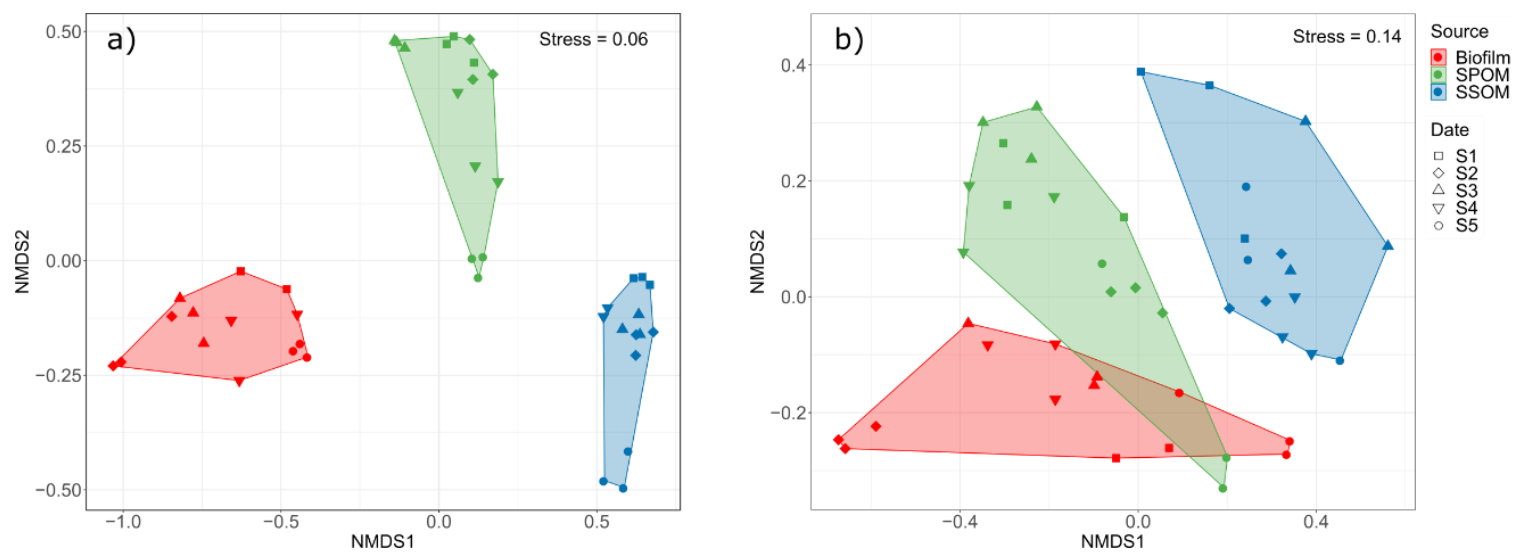

Figure 2: n-MDS based on the total pigment (a) and fatty acid (b) compositions of organic matter sources (Biofilm, suspended particulate organic matter (SPOM), superficial sedimentary organic matter $(\mathrm{SSOM}))$. $S 1$ to $S 5$ correspond to the sampling dates $\left(\mathrm{S} 1=26^{\text {th }}\right.$ February, $\mathrm{S2}=21^{\text {st }}$ March, $\mathrm{S3}=$ $28^{\text {th }}$ March, S4 $=12^{\text {th }}$ April and S5 $=14^{\text {th }}$ June).

Total FA concentration did not show significant temporal variations for any OM sources (Figure $3 a)$, with the biofilm always exhibiting higher concentration of total FA than SSOM $(p<0.05$ at each sampling date). Chlorophyll (chl) $a$ concentration increased over time in PPOM up to sampling date S4 (1.8 $\left.\pm 0.2 \mu \mathrm{g} \mathrm{L}^{-1}\right)(p<0.05)$ as well as in biofilm (reaching $3.9 \pm 1 \mathrm{mg} \mathrm{m}^{-2}$ at S5) even if differences were not significant due to high between-samples variability (Figure 3b). Chl $a$ concentration in SSOM remained constant and was lower than in biofilm for each date $(p<0.05$ in all cases). Fucoxanthin concentration increased over time for both SPOM and SSOM ( $p<0.05$ and $p<0.05$, respectively), followed by a decrease in S5 (Figure 3c). Fucoxanthin concentration is the highest in biofilm, which showed a similar increasing trend that is not statistically supported because of high variability between samples. The chl $b$ : chl $a$ ratio was 3 to 7 -fold higher for biofilm than for SSOM $(p<0.001)$ and SPOM $(p<0.001)$ (Figure 3d). Fucoxanthin: $\operatorname{chl} a$ (Figure 3e) and $\operatorname{chl} c$ : $\operatorname{chl} a$ (Figure 3f) ratios did not show clear temporal patterns for any OM sources and. However, they were 5 to 50 -fold higher in SSOM than in SPOM $(p<0.001)$ and biofilm $(p<0.001)$ over the studied period, respectively. 



Figure 3: Total fatty acids (a), chlorophyll $a(b)$ and fucoxanthin (c) concentrations, and ratios between chlorophyll $b$ (d), fucoxanthin (e), and chlorophyll $c$ (f) over chlorophyll $a$ (mean $\pm \mathrm{SD}, \mathrm{n} \geq 2$ ) of organic matter sources (Biofilm, suspended particulate organic matter (SPOM), superficial sedimentary organic matter $(\mathrm{SSOM}))$. S1 to S5 correspond to the sampling dates $\left(\mathrm{S} 1=26^{\text {th }}\right.$ February, $S 2=21^{\text {st }}$ March, S3 $=28^{\text {th }}$ March, S4 $=12^{\text {th }}$ April and S5 $=14^{\text {th }}$ June).

\subsubsection{Stable isotopes composition}

The three OM sources were well discriminated by their $\delta^{13} \mathrm{C}$ and $\delta^{15} \mathrm{~N}$ values over the studied period. between the two factors was significant $(p<0.001, p<0.01$ and $p<0.001$, respectively). PPOM was always depleted in ${ }^{13} \mathrm{C}$ compared to RPOM $(p<0.001$ at each date) and biofilm $(p<0.01$ at each date) (Figure $4 \mathrm{a}$, Table S3). Significant temporal $\delta^{13} \mathrm{C}$ variations were only observed in biofilm, with higher values at $\mathrm{S} 5$ than at S2 $(p<0.001)$ or S4 $(p<0.001)$. Biofilm was significantly enriched in ${ }^{15} \mathrm{~N}$ compared to both PPOM $(p<$ $0.001)$ and RPOM $(p<0.001)$ (Figure 4b, Table S3). There was no interaction between OM sources and sampling dates $(p=0.26)$. 

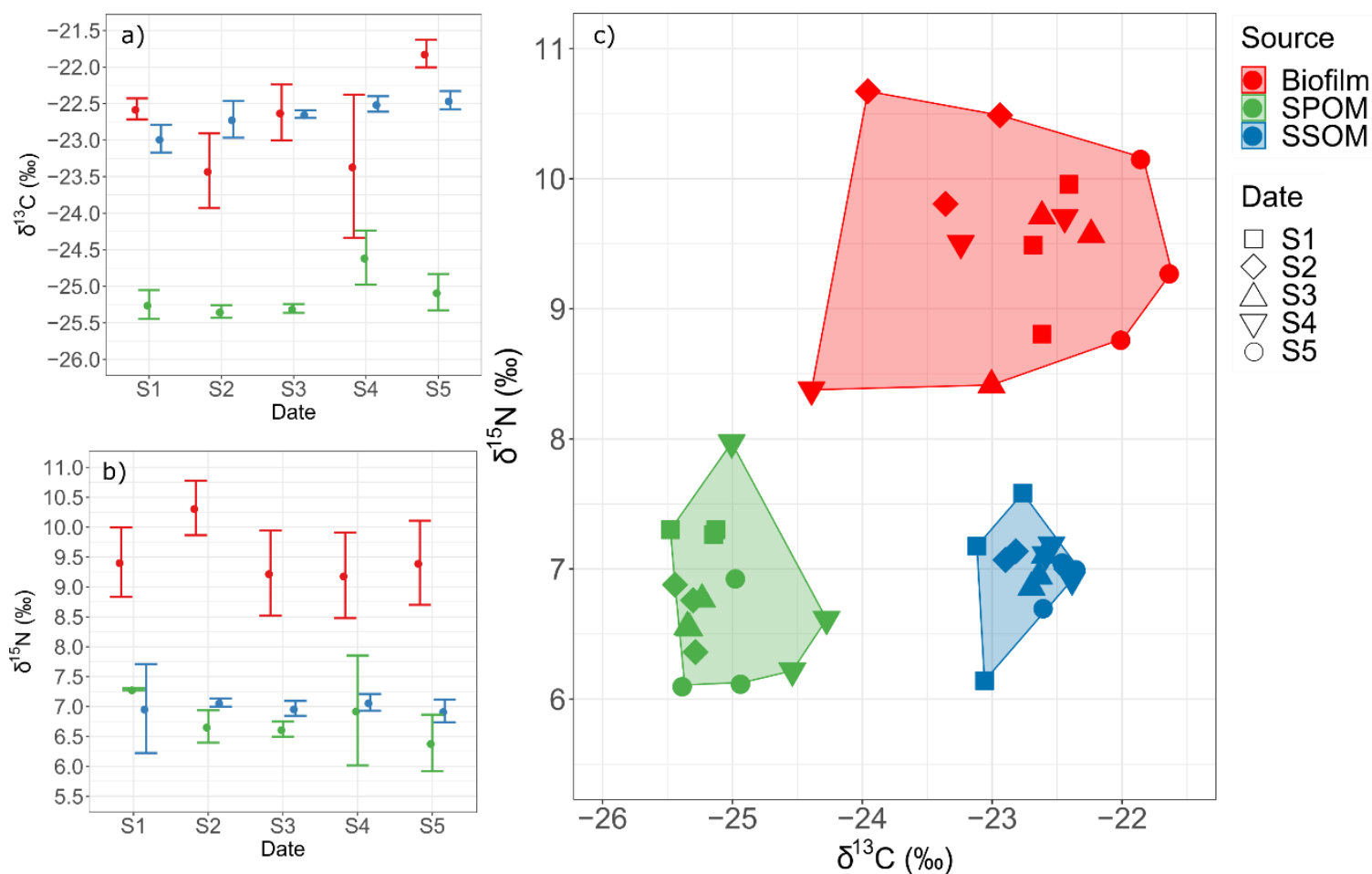

Figure 4: $\delta^{15} \mathrm{~N}(\mathrm{a})$ and $\delta^{13} \mathrm{C}(\mathrm{b})$ isotopic compositions (mean $\pm \mathrm{SD}, \mathrm{n}=3$ ), and overall isotopic biplot (c) obtained of organic matter sources (Biofilm, suspended particulate organic matter (SPOM), superficial sedimentary organic matter (SSOM)). S1 to S5 correspond to the sampling dates ( $\mathrm{S} 1=26^{\text {th }}$ February, S2 $=21^{\text {st }}$ March, S3 $=28^{\text {th }}$ March, S4 $=12^{\text {th }}$ April and S5 $=14^{\text {th }}$ June).

\subsection{Crepidula fornicata}

\subsubsection{Fatty acids composition}

FA composition of $C$. fornicata significantly differed between ontogenic stages and sampling dates ( $p<0.001$ in both cases) and the interaction between the two factors was significant $(p<0.001)$. The analysis of multivariate dispersion was also significant $(p<0.05)$, indicating that multivariate dispersion was not homogeneous. This was clearly illustrated by the n-MDS (when comparing the convex hull areas) where motile males showed much higher variation than sessile females and sessile males exhibited an intermediate level of variation (Figure 5). Pairwise SIMPER analyses between ontogenic stages revealed that sessile males were mainly characterized by saturated FA 16:0 and 18:0, especially at the two first sampling dates (Table S4). Sessile females differed from both motile and sessile males by higher percentages of $\mathrm{C}_{20}$ FA such as 20:5n-3, 22:6n-3 and 20:1n-11, but also higher percentages of odd branched FA as iso17:0 (Table S4). Sessile males showed an overall comparable FA composition than sessile females but exhibited higher variability between sampling dates, as shown by the n-MDS. The SIMPER analyses performed between dates revealed that FA that most contributed to the observed temporal changes were the FA 16:0, 18:0 and 22:6n-3 decreasing over time, and the FA 20:5n-3 and 16:1n-7 increasing over time, all accounting for approximately $45 \%$ of the dissimilarity over the 5 sampling dates (Table S4). 


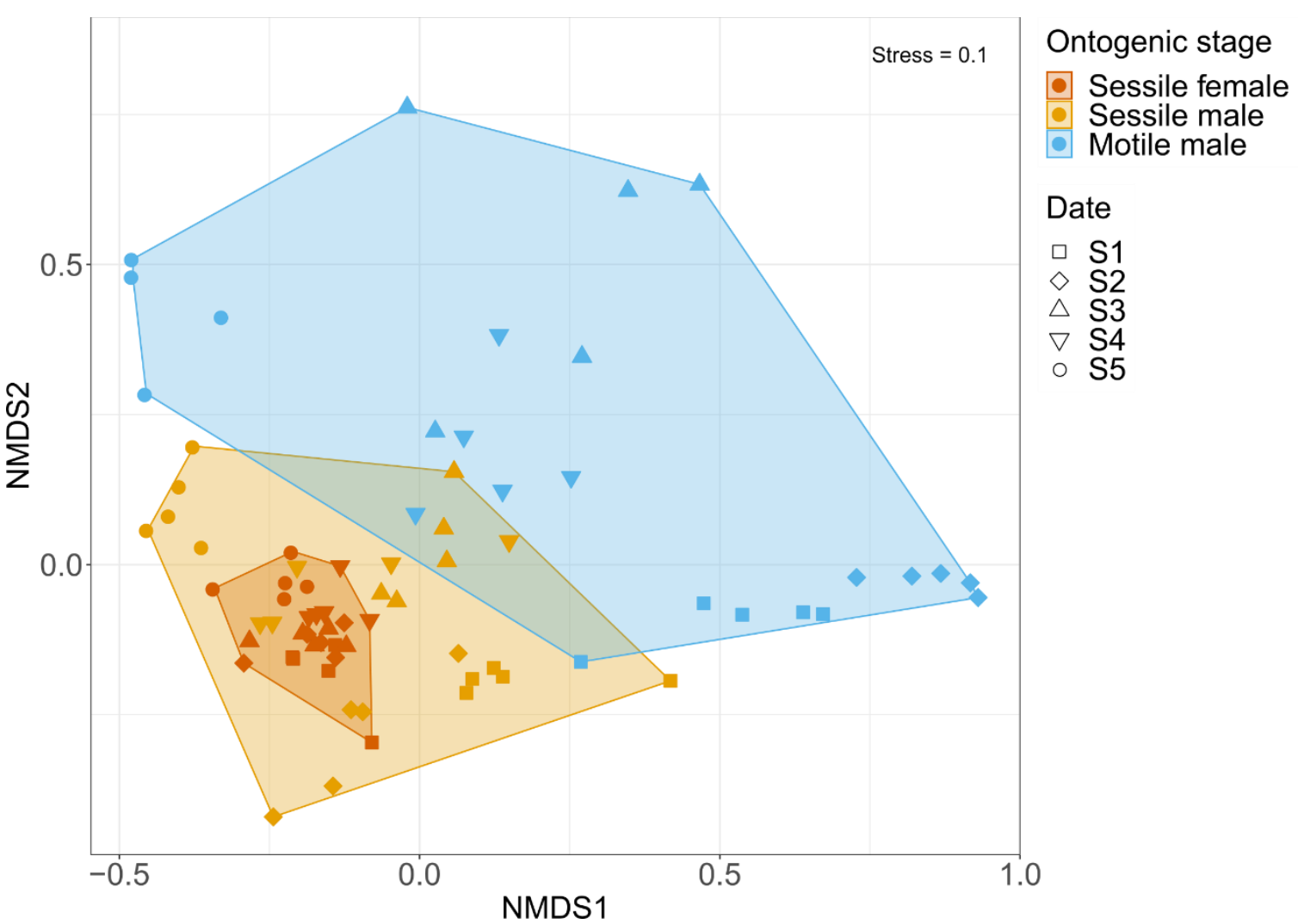

Figure 5: n-MDS based on the total fatty acid compositions of ontogenic stages of Crepidula fornicata (motile males, sessile males, sessile females). S1 to S5 correspond to the sampling dates $\left(\mathrm{S1}=26^{\text {th }}\right.$ February, S2 $=21^{\text {st }}$ March, S3 $=28^{\text {th }}$ March, S4 $=12^{\text {th }}$ April and S5 $=14^{\text {th }}$ June).

All FA percentages and ratios changed significantly between sampling dates ( $p<0.001$ in all cases) and between ontogenic stages $(p<0.05$ in all cases, except for 16:1n-7 and 18:4n-3). The interaction terms were always significant $(p \leq 0.05)$. Overall, temporal variations in FA composition were the highest in motile males, the lowest for females and intermediate for sessile males.

PUFA/SFA ratio increased over time for both motile and sessile males but remained constant in females (Figure 6a). There was no significant difference between ontogenic stages at sampling date S5. The relative abundance of branched FA was quite variable but significantly higher in sessile females than in motile males $(p>0.05)$ (Figure 6b). The highest values in branched FA was recorded in sessile females at S1 (11.2 \pm 4.3$)$ and the lowest in sessile males at S5 (3.8 \pm 1$)$. The ratio between 20:5n-3 and 22:6n-3 exhibited temporal variations for all ontogenic stages (Figure 6c), with a strong increase in S5 ( $p<0.001$ in all cases) where values ranged from $2.5 \pm 0.5$ in sessile females to $4 \pm 0.6$ in motile males. The FA 16:1n-7 followed the same trend as the 20:5n-3 / 22:6n-3 ratio with a more gradual increase over time for all ontogenic stages (Figure $6 \mathrm{~d}$ ). The highest values (from $3.6 \pm 0.9$ in sessile females to $6.4 \pm 1.9$ in motile males) were also recorded at S5. The FA 18:4n-3 also showed strong temporal variations in all ontogenic stages (Figure 6e), with an increase up to S4 followed by a decrease at S5. Finally, the n-3/n-6 ratio showed no temporal variation for sessile females but increased significantly over time up to S4 in both sessile ( $p<0.01$ in all cases) and motile males ( $p<0.05$ in all cases) (Figure 6f). 

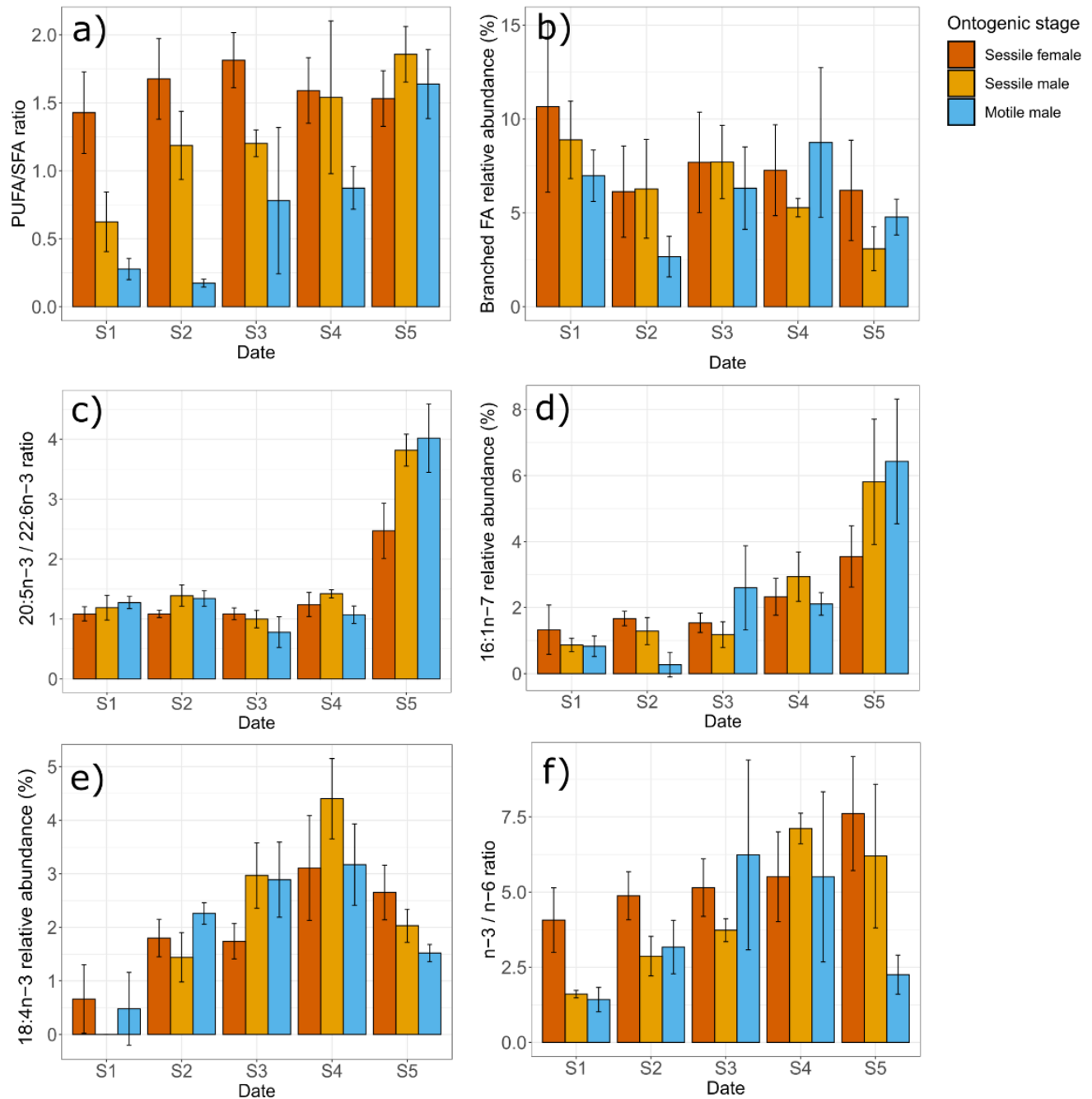

Figure 6: Relative abundance of fatty acids (FA) in the three ontogenic stages of Crepidula fornicata (motile males, sessile males, sessile females) (mean \pm SD, $n=5$ ): (a) Polyunsaturated FA / Saturated FA ratio, (b) Branched FA, (c) 20:5n-3 / 22:6n-3 ratio, (d) 16:1n-7, (e) 18:4n-3 and (f) n-3/n-6 ratio. S1 to $S 5$ correspond to the sampling dates $\left(\mathrm{S1}=26^{\text {th }}\right.$ February, $\mathrm{S2}=21^{\text {st }}$ March, $\mathrm{S3}=28^{\text {th }}$ March, $\mathrm{S4}=$ $12^{\text {th }}$ April and S5 $=14^{\text {th }}$ June).

\subsubsection{Stable isotopes composition}

Overall, the three ontogenic stages exhibited similar isotopic patterns over time (Figures $7 \mathrm{a}$ and $7 \mathrm{~b}$, respectively). No interactions were found between ontogenic stage and sampling date, both for carbon ( $p=$ $0.6)$ and nitrogen $(p=0.27)$. Motile males were significantly depleted in ${ }^{13} \mathrm{C}$ compared to sessile females $(p$ $<0.05)$ and significantly depleted in ${ }^{15} \mathrm{~N}$ compared to both sessile females $(p<0.001)$ and males $(p<0.05)$. Significant temporal variations were observed for $\delta^{13} \mathrm{C}(p<0.001)$ with a marked ${ }^{13} \mathrm{C}$ enrichment at S5 compared to all other sampling dates ( $p<0.05$ in all cases), up to $2 \%$ when compared to S4. A significant temporal decrease in $\delta^{15} \mathrm{~N}$ was found $(p<0.001)$ for all ontogenic stages. 

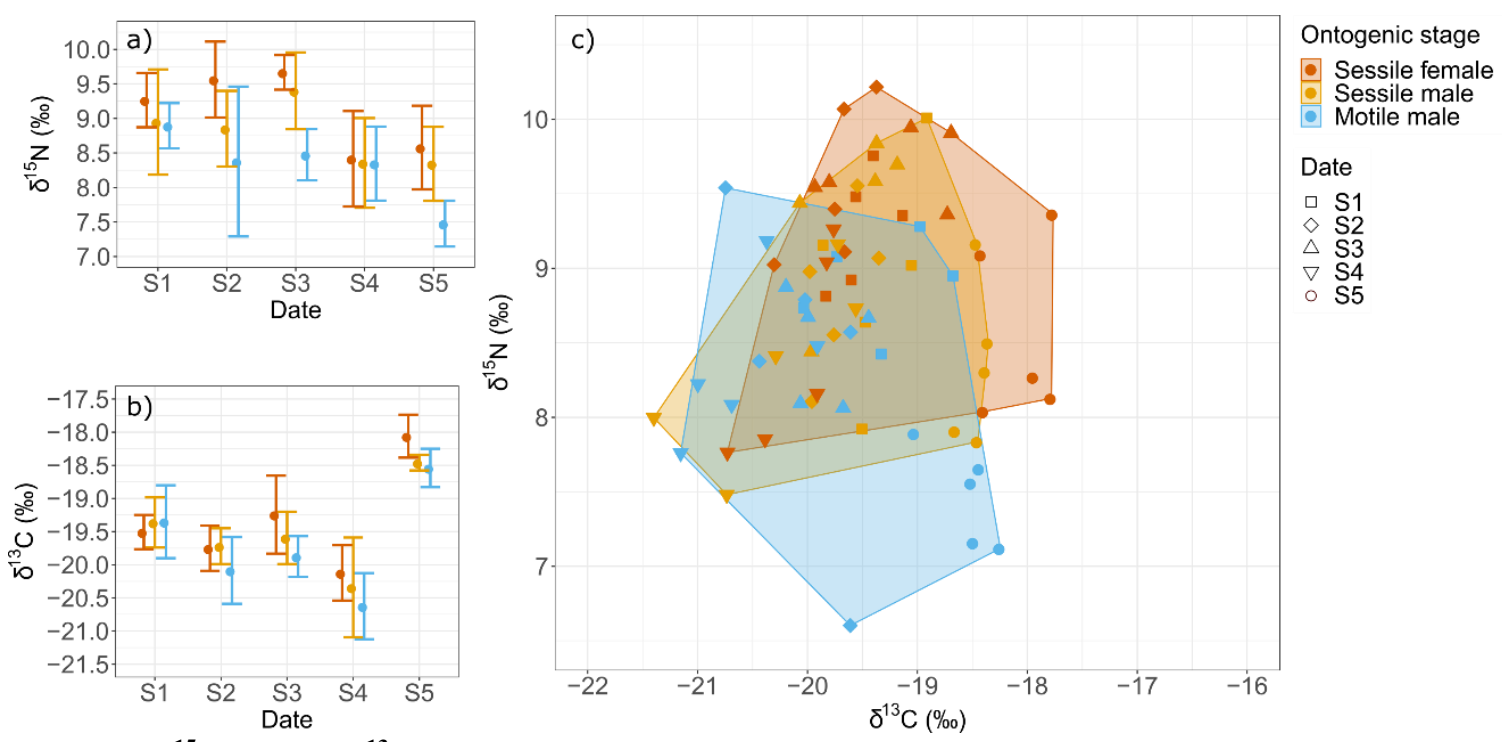

Figure 7: $\delta^{15} \mathrm{~N}$ (a) and $\delta^{13} \mathrm{C}(\mathrm{b})$ isotopic compositions (mean $\pm \mathrm{SD}, \mathrm{n}=\mathbf{5}$ ), and corresponding isotopic biplot (c) for three ontogenic stages of Crepidula fornicata (motile males, sessile males, sessile females). S1 to $S 5$ correspond to the sampling dates $\left(S 1=26^{\text {th }}\right.$ February, $S 2=21^{\text {st }}$ March, $S 3=28^{\text {th }}$ March, $S 4=$ $12^{\text {th }}$ April and S5 $=14^{\text {th }}$ June).

\section{Discussion}

C. fornicata is a widespread invasive gregarious gastropod. The aim of this study was to investigate the trophic niche of this species and quantified intra-specific diet shift associated with ontogenic behavior changes (i.e., motile male to sessile female). A multi trophic markers assessment was conducted over spring to characterized potential OM sources and inferred their assimilation in C. fornicata tissues.

\subsection{Composition and availability of potential food sources}

Suspended particulate (SPOM) and superficial sedimentary (SSOM) organic matter as well as biofilm associated with $C$. fornicata shells were well discriminated by their pigment, fatty acid and stable isotope compositions, for each sampling date. When compared to marine POM $(-22.3 \pm 1.2 \%)$, as measured over the same period close to the mouth of the bay of Brest (data from the French Coastal Monitoring Network SOMLIT; http://somlit.epoc.u-bordeaux1.fr/fr/) and terrestrial POM (-27.5 $\pm 1.2 \%$ ), as measured in terrestrial inputs nearby our study site by Mortillaro et al. (2014), the $\delta^{13} \mathrm{C}$ obtained for SPOM $(-25.4 \pm 0.7$ $\%$ ) suggests a significant terrestrial influence at our study site, as mentioned by Marchais et al. (2013). SPOM over our studied period showed comparable chlorophyll $a$ biomass $\left(0.4-1.8 \mu \mathrm{g} \mathrm{L}^{-1}\right)$ than currently encountered in other areas of the bay of Brest (ca. $0.3-5 \mu \mathrm{g} \mathrm{L}{ }^{-1}$, Chatterjee et al. 2013). High percentage of fucoxanthin and alloxanthin suggested the presence of Bacillaryophyta (i.e., diatoms) and Cryptophyta in the water column, respectively (Brotas and Plante-Cuny, 2003; Roy et al., 2011).

Using the SOMLIT weekly monitoring of chlorophyll $a$ and marine POM $\delta^{13} \mathrm{C}$, a typical ${ }^{13} \mathrm{C}$ enrichment $(\sim 3$ $\%$ ) was noticeable during a phytoplankton bloom that occurred between May $25^{\text {th }}$ and June $1^{\text {st }}$ in the bay. This bloom was mainly composed by three diatoms: Cerataulina pelagica $\left(\begin{array}{llll}1.1 & 10^{6} & \text { cells } \mathrm{L}^{-1}\end{array}\right)$, Leptocylindricus danicus $\left(4.710^{4}\right.$ cells L $\left.{ }^{-1}\right)$ and Rhizosolenia imbricata $\left(1.210^{4}\right.$ cells L $\left.^{-1}\right)$ (data extracted from the REPHY network, IFREMER). While this bloom was not sampled in the PPOM sampling set, the ${ }^{13} \mathrm{C}$ enrichment was evidenced in the individuals of $C$. fornicata collected at S5 (14 ${ }^{\text {th }}$ June).

Among the three sources of organic matter, SSOM showed the most homogeneous isotopic composition over time, which is unexpected as SSOM is often considered as a mixture of pelagic and benthic $\mathrm{OM}$ sources and consequently highly variable according to $\mathrm{OM}$ sources proportions and isotopic compositions SSOM appeared here as a complex mixture of low and high quality OM (Lefebvre et al., 2009; Rigolet et al., 2014). On one hand, it was characterized by i) pheophorbide $a$ and pheophytin $a$, which are degradation products of chlorophyllide $a$ and chlorophyll $a$, respectively (Brotas and Plante-Cuny, 1998; Cartaxana et al., 2003), ii) odd branched FA (such as ant15:0) and the 18:1n-7 indicating the presence of 

fatty acids 22:0 which confirms the presence of a refractory terrestrial contribution in this environment (Canuel, 2001). On the other hand, SSOM exhibited the highest PUFA/SFA ratio most of the time (Table S1), suggesting higher quality/lability compared to SPOM and biofilm (Connelly et al., 2015, 2016; Parrish et al., 2005). This was confirmed by high Fucoxanthin / Chl $a$ and $\mathrm{Chl} c / \mathrm{Chl} a$ ratios which indicated a higher contribution of diatoms in SSOM than in SPOM and biofilm (Brotas and Plante-Cuny, 2003). Interestingly, fucoxanthin concentrations measured both in SSOM and biofilm were comparable to those observed on intertidal mud flats (Barranguet et al., 1997; Cartaxana et al., 2006). This blue-light absorbing pigment, and the very low light irradiance of our study site (0.01\%, Figure S1) strongly suggested that low light acclimated diatoms contributed to the SSOM at our study site (McGee et al., 2008).

Biofilm scrapped on shells of $C$. fornicata showed higher chlorophyll $a$ concentration than the surrounding sediment, suggesting higher biomass of primary producers on shells (Androuin et al., 2018). The high percentages of chl $b$ and neoxanthin, as well as the $\mathrm{Chl} b / \mathrm{Chl} a$ ratio in the biofilm also suggest that chlorophytes were abundant on shells (Brotas and Plante-Cuny, 2003). While these results were not supported by FA (e.g., 18:3n-3 or 18:4n-3 characterizing chlorophytes, Fleurence et al. 1994), mollusk shells are currently inhabited by microchlorophytes or macrochlorophytes propagules (Barillé et al., 2017; Mineur et al., 2007). FA characterizing the biofilm were 18:0 and 20:4n-6. While 18:0 is an ubiquitous FA in marine environment (Kelly and Scheibling, 2012), the 20:4n-6 can be found in large proportion in red algae but also in brown ones (Fleurence et al., 1994; Kelly and Scheibling, 2012). It is worth noting that $C$. fornicata shells were partly covered with crustose red algae in our study site (pers. obs.). The high concentration of fucoxanthin also suggests the presence of high biomass of diatoms on these shells, as already mentioned by Ní Longphuirt et al. (2007). For instance, the biomass in biofilm was $~ 10$ times higher than in the surrounding SSOM. The fact that biofilm was ${ }^{15} \mathrm{~N}$-enriched by $\sim 2.5 \%$ compared to SSOM may indicate that primary producers that compose this biofilm could use dissolved nitrogen derived from $C$. fornicata's excretion products, which is a well-known process in benthic coastal ecosystems (Arzul, 2001; Prins et al., 1998; Ragueneau et al., 2002). While the excretion product (i.e., ammonium) is expected to be ${ }^{15} \mathrm{~N}$-depleted relative to C. fornicata tissues (DeNiro and Epstein, 1981), it could still be ${ }^{15} \mathrm{~N}$-enriched compared to the available dissolved nitrogen in the environment (Cifuentes et al., 1989; Raimonet et al., 2013; Wainright and Fry, 1994). This could indicate that nutrients are not a limiting factor for primary producers inhabiting C. fornicata shells, making them available for benthic consumers throughout the year provided that sufficient light reach the sea floor. The fact that chlorophyll $a$ concentration decreased in SPOM after the spring bloom, but not in the biofilm, strongly support this hypothesis.

\subsection{Trophic niche of $C$. fornicata, in relation to ontogenic changes}

Trophic markers suggested an overall similar trophic niche of Crepidula fornicata across ontogenic stages, as shown by the covariation in both SI and FA compositions over the studied period. The slipper limpet is an opportunistic suspension-feeder that exploits both pelagic and benthic particulate OM in varying proportions according to the season and sources availability. However, differences in FA composition, and to a lesser extent in SI composition, were noticeable between ontogenic stages. These differences at each sampling date likely reflect ontogenic physiological changes link to growth rate and energetic demand rather than profound changes in diet.

Overall, SI ratios showed that all ontogenic stages had similar isotopic niches, although the niche of sessile females does not fully overlap with those of motile males. According to the respective SI ratios of potential food sources (Biofilm, SPOM, SSOM and marine POM) and those of $C$. fornicata tissues, and considering classical diet to consumer trophic enrichment factor $(\sim 0.75-1 \%$ for carbon and $\sim 2.5-2.74 \%$ for nitrogen, (Caut et al., 2009; McCutchan et al., 2003), it is likely that $C$. fornicata relies either on SSOM or marine POM depending of the season and food availability in the water column. During lower food availability period (i.e., end of winter and early spring), it is difficult to disentangle SSOM from marine POM since their SI signals do not differ. However marine POM was sampled close to the Bay entrance with higher oceanic influence, whereas SPOM was sampled just above the $C$. fornicata beds around mid and flood tide to ensure mixing with oceanic water. Therefore, SPOM was readily more available than marine POM for the slipper limpet. It is then reasonable to assume that SI composition of $C$. fornicata refers to SSOM rather than marine POM, which can be exploited through regular resuspension events linked to tidal currents (Beudin, 2014). After the spring phytoplankton bloom that occurred in the bay of Brest at the end of May, producing 
a ${ }^{13} \mathrm{C}$ enrichment in the water column $\left(\sim 3 \%\right.$ ), a similar ${ }^{13} \mathrm{C}$ enrichment was found for all stages of $C$. fornicata $(\sim 2 \%)$. These results clearly showed that adults as well as young individuals of $C$. fornicata benefited from the spring bloom. However, minor but consistent isotopic differences were also found between ontogenic stages at each sampling date, which cannot necessarily be attributed to an ontogenic diet shift. Indeed, inferring diet shift using SI ratios may be hampered by the effects of physiological changes occurring during ontogeny such as gonadal maturation, metabolic rate or differential tissue growth between youngs and adults. Such physiological processes can modify the isotope signal of tissues even without significant change of diet, as evidenced in several species (Blanchet-Aurigny et al., 2012; Hentschel, 1998; Rossi et al., 2004). The isotopic dynamic also depends on tissue turnover rate (McCutchan et al., 2003; Vander Zanden et al., 2015). Lefebvre and Dubois (2016) analysed trophic enrichment factor and turnover rate in several marine benthic invertebrates, including $C$. fornicata. They showed a clear negative relationship between growth and enrichment factor values: when the body mass is increasing rapidly and the individual growing fast (high turnover), enrichment factors are expected to be low, and conversely. Young motile males of Crepidula fornicata are growing more rapidly than larger sessile males or even larger females (Hoagland, 1978; Walne, 1956), and consequently have a higher growth rate and a higher metabolic rate (Bayne and Newell, 1983). Enrichment factors are then expected to be much smaller for motile males, than sessile males or females, for which energy allocation is mainly directed to gamete production rather than other tissue growth. So, a similar diet in all ontogenic stages could very likely lead to differences in SI ratios such as those presented in Figure $7 \mathrm{c}$. Even if motile males were analysed in toto (including muscle tissue with longer turnover rate), we believe that this does not biased interpretations of between-stages differences over the studied period. Analysing only tissues with fast turnover rate (as we did for sessile individuals) would have increased these between-stages differences.

Neutral lipids represent essential energy reserves for sustaining early life stages of marine molluscs and play a key role in their settlement, habitat selectivity and recruitment (Barbier et al., 2017; Pernet and Tremblay, 2004; Tremblay et al., 2007). Contrary to polar lipids, mostly involved in membrane regulation, FA incorporated in the neutral fraction are largely unaltered and reflect the diet in a more straightforward manner than polar lipids (Dalsgaard et al., 2003). Therefore, extracting FA from this specific class of lipids from a tissue with a rapid turnover (i.e., digestive gland) should allow assessing rapid changes in the diet (McCutchan et al., 2003). As suggested above by SI data, FA profiles showed a clear temporal variation in food sources utilization for the three ontogenic stages. This temporal pattern resulted from three distinct groups of sampling dates (Figure 5). The two first ones (S1 and S2) likely corresponded to a period that integrated the trophic signal of winter season's food sources, whereas the last one (S5) clearly corresponded to the assimilation of the spring phytoplankton bloom. The two-intermediate sampling dates (S3 and S4) corresponded to the transition with an increase infood availability. As shown earlier with SI, all ontogenic stages of $C$. fornicata may have probably exploited SSOM before the spring bloom when food in the water column is less available. In this pool of OM, FA revealed that slipper limpets likely fed on benthic diatoms (as suggested by 16:1n-7 and 20:5n-3; Dunstan et al. 1992; Napolitano et al. 1997; Passarelli et al. 2012), dinoflagellates (22:6n-3; Zhukova and Aizdacher 1995; Lavaud et al. 2018) and bacteria (Branched FA and 18:1n-7; Perry et al. 1979; Zhukova et al. 1992; Haack et al. 1994), which is in agreement with previous interpretations done in other comparable coastal bays (Dubois et al., 2014; Leroy et al., 2013). In sediment, bacteria are often associated with detritus and are therefore not considered as a high-quality food source (Dalsgaard et al., 2003). This is confirmed by the PUFA/SFA ratio, a biomarker of fresh vs. detritic OM (Connelly et al., 2015, 2016; Parrish et al., 2005), which was lower in the slipper limpet ( 1.5, our study) than in other suspension-feeding species of the bay of Brest, such as Pecten maximus ( 2.8, Lavaud et al. 2018) or Ophiotrix fragilis ( 2, Blanchet-Aurigny et al. 2015). The fact that $C$. fornicata lacks pre-ingestive mechanisms for particle selection likely explains their opportunistic trophic behaviour based on both fresh and detritic organic matter (Beninger et al., 2007). After spring bloom, the percentages of diatom's markers 16:1n-7 and 20:5n-3 drastically increased in C. fornicata's tissue, as well as the 20:5n-3/22:6n-3 ratio, confirming that all ontogenic stages of $C$. fornicata benefit from this food supply from the water column (Budge and Parrish, 1998; Lavaud et al., 2018).

Besides, the FA 18:4n-3 showed an increasing contribution over time for ontogenic stages. According to the literature, this FA may originate from different primary producers such as dinoflagellates (Budge and Parrish, 1998) or green macroalgae (Fleurence et al., 1994; Kelly and Scheibling, 2012). Considering the absence or low temporal variation observed for others dinoflagellate biomarkers (peridinin pigment and 22:6n-3 FA) in the OM sources and the frequent seasonal accumulation of green macroalgae 
near our study site (Study Centre for Algal Promotion, http://www.ceva.fr; Ragueneau et al. 2018), we can expect a seasonal trophic role of these green macroalgae for $C$. fornicata at our study site, probably in the form of detrital particles. The FA 20:1n-11 was found in relative high abundance in C. fornicata (4-6\%). Although it is known to be a biomarker of copepod in tropical estuaries (Bachok et al., 2003), the ${ }^{15} \mathrm{~N}$ enrichment of $C$. fornicata compared to SPOM was not high enough to suggest a significant contribution of zooplankton in its diet (Kopp et al., 2015). Comparable percentages of 20:1n-11 were reported for Ophiotrix fragilis in the bay of Brest (Blanchet-Aurigny et al., 2015), evidencing that this FA was not a good biomarker of zooplankton for the species considered.

Contrary to SI, FA compositions of the three ontogenic stages of $C$. fornicata showed low overlap, especially between motile and sessile limpets. Considering that lipids and fatty acids profiles are age- and sex-specific (Correia et al., 2003; Pernet et al., 2012), some changes in FA compositions are then likely to originate from physiological changes between ontogenic stages. During winter period, motile males were characterized by higher proportions of SFA such as 16:0 (25-34 \%) and 18:0 (27-36\%). These FA are very common in marine organisms and do not necessarily reflect a specific diet (Dalsgaard et al., 2003; Kelly and Scheibling, 2012). Moreover, despite the dietary interest of short-chain SFA, where energy is more efficiently released via beta-oxidation than for PUFA (Langdon and Waldock, 1981), temperature may also influence the process of their utilization (Pernet et al., 2007). For example, it has been experimentally demonstrated that cold-acclimated oysters $\left(5-7^{\circ} \mathrm{C}\right)$ have a clear preference for PUFA (n-3) over SFA (16:0) as fuel for energy compared to 'temperate' oysters (Chu and Greaves, 1991). The lower utilization of SFA in coldacclimated oysters has been attributed to the fact that SFA are not in the liquid phase under cold temperature, thus making them less accessible for catabolic processes. In Crepidula fornicata, young individuals have proportionally less energy reserves than adults (Guérin, 2004) and are more subjected to low temperature effects due to a higher surface-to-volume ratio (Diederich et al., 2015). Hence, the lower utilization of SFA could explain their higher SFA percentages during winter period in the bay of Brest, where temperature fall down to $7^{\circ} \mathrm{C}$ (Figure S2). Moreover, the weight-specific metabolic rate, which is higher in smaller organisms (Bayne and Newell, 1983; Bougrier et al., 1995), could be exacerbated in C. fornicata because motile males are more active than adults through their motility (Coe, 1936; Hoagland, 1978; Walne, 1956). Together, these results explain the higher variability in their FA compositions, among individuals but also between sampling dates. They also suggest that young motile individuals of $C$. fornicata, having less energetic storage in winter while having more energetic needs, are probably in poor energetic condition during this period.

As we measured neutral FA in digestive gland and gonad simultaneously (because the digestive gland cannot be isolated from the gonad), the level of lipid storage and FA composition may also depend on their sexual development stage. Indeed, females allocate more energy than males in the reproduction due to maternal gametogenesis (Deslous-Paoli and Héral, 1986; Leroy et al., 2013). As an illustration of FA composition changes, the $n-3 / n-6$ ratio increased over time for both sessile and motile males whereas it remains unchanged in females. This may be linked to a preferential allocation of n-3 to early embryos, which showed an increase over the reproductive period of the slipper limpet (Leroy et al., 2013).

Finally, we found a surprisingly high amount of non-methylene interrupted (NMI) FA in neutral lipids (5-10\% on average in sessile stages) while these FA are preferentially incorporated in polar lipids (e.g., $8 \%$ of NMI FA reported in polar lipids of $C$. fornicata by Dagorn et al. 2014). NMI FA are specific PUFA de novo synthesized by marine molluscs (Barnathan, 2009; Zhukova, 1991). Although their biological role and function are not well understood, the NMI FA have an unusual unsaturation pattern that confers to cell membranes a higher resistance to oxidative processes and microbial lipases than for the common PUFA. The content of NMI FA may thus represent a biochemical adapting feature of benthic organisms to their specific habitat (Barnathan, 2009). Because $C$. fornicata showed ontogenic histological changes in its foot (the largest part of the body) when becoming completely sessile (Androuin et al., 2019; Chaparro et al., 1998), high amount of such FA may act as a protection against potential negative effect of the sessility.

\section{Acknowledgements}

We thank the PSO and LIPIDOCEAN analytical facilities for stable isotope and fatty acid facilities, respectively (Oanez Lebeau, Antoine Bideau and Rudolph Corvaisier). We are grateful to Aline BlanchetAurigny for commenting upon preliminary versions of this manuscript. We also thank the LEBCO diving team (Amélia Curd, Xavier Caisey and Aurélien Tancray) for providing biological samples. TA was funded 
by an IFREMER, LabexMER and Region Bretagne PhD grant. This work was funded by the TOTAL foundation for biodiversity.

\section{References}

Anderson, M.J., 2001. A new method for non-parametric multivariate analysis of variance. Austral Ecology 26, 32-46. https://doi.org/10.1111/j.1442-9993.2001.01070.pp.x

Androuin, T., Dubois, S.F., Decottignies, P., Pelleter, E., Carlier, A., 2019. The dark side of soft tissues: Unexpected inorganic carbonate in the invasive slipper limpet Crepidula fornicata and its implications for stable isotope interpretations. Rapid Commun Mass Spectrom 33, 107-115. https://doi.org/10.1002/rcm.8322

Androuin, T., Polerecky, L., Decottignies, P., Dubois, S.F., Dupuy, C., Hubas, C., Jesus, B., Le Gall, E., Marzloff, M.P., Carlier, A., 2018. Subtidal microphytobenthos: a secret garden stimulated by the engineer species Crepidula fornicata. Front. Mar. Sci. 5, 475. https://doi.org/10.3389/fmars.2018.00475

Arbach Leloup, F., Desroy, N., Le Mao, P., Pauly, D., Le Pape, O., 2008. Interactions between a natural food web, shellfish farming and exotic species: The case of the Bay of Mont Saint Michel (France). Estuarine, Coastal and Shelf Science 76, 111-120. https://doi.org/10.1016/j.ecss.2007.06.011

Arzul, G., 2001. Effect of marine animal excretions on differential growth of phytoplankton species. ICES Journal of Marine Science 58, 386-390. https://doi.org/10.1006/jmsc.2000.1038

Bachok, Z., Mfilinge, P.L., Tsuchiya, M., 2003. The diet of the mud clam Geloina coaxans (Mollusca, Bivalvia) as indicated by fatty acid markers in a subtropical mangrove forest of Okinawa, Japan. Journal of Experimental Marine Biology and Ecology 292, 187-197. https://doi.org/10.1016/S00220981(03)00160-6

Barbier, P., Meziane, T., Forêt, M., Tremblay, R., Robert, R., Olivier, F., 2017. Nursery function of coastal temperate benthic habitats: New insight from the bivalve recruitment perspective. Journal of Sea Research 121, 11-23. https://doi.org/10.1016/j.seares.2016.12.007

Barillé, L., Le Bris, A., Méléder, V., Launeau, P., Robin, M., Louvrou, I., Ribeiro, L., 2017. Photosynthetic epibionts and endobionts of Pacific oyster shells from oyster reefs in rocky versus mudflat shores. PLoS ONE 12, e0185187. https://doi.org/10.1371/journal.pone.0185187

Barnathan, G., 2009. Non-methylene-interrupted fatty acids from marine invertebrates: Occurrence, characterization and biological properties. Biochimie 91, 671-678. https://doi.org/10.1016/j.biochi.2009.03.020

Barranguet, C., Herman, P.M.J., Sinke, J.J., 1997. Microphytobenthos biomass and community composition studied by pigment biomarkers: importance and fate in the carbon cycle of a tidal flat. Journal of Sea Research 38, 59-70. https://doi.org/10.1016/S1385-1101(97)00032-4

Bayne, B.L., Newell, R.C., 1983. Physiological energetics of marine molluscs, in: The Mollusca. Elsevier, pp. 407-515. https://doi.org/10.1016/B978-0-12-751404-8.50017-7

Beninger, P., Decottignies, P., Guiheneuf, F., Barillé, L., Rincé, Y., 2007. Comparison of particle processing by two introduced suspension feeders: selection in Crepidula fornicata and Crassostrea gigas. Mar. Ecol. Prog. Ser. 334, 165-177. https://doi.org/10.3354/meps334165

Beudin, A., 2014. Dynamique et échanges sédimentaires en rade de Brest impactés par l'invasion de la crépidule. Université de Bretagne Occidentale.

Blanchard, M., 1997. Spread of the slipper limpet Crepidula fornicata (L. 1758) in Europe. Current state and consequences. Scientia Marina 61, 10.

Blanchard, M., Pechenik, J.A., Giudicelli, E., Connan, J.-P., Robert, R., 2008. Competition for food in the larvae of two marine molluscs, Crepidula fornicata and Crassostrea gigas. Aquat. Living Resour. 21, 197-205. https://doi.org/10.1051/alr:2008025

Blanchet-Aurigny, A., Dubois, S., Quéré, C., Guillou, M., Pernet, F., 2015. Trophic niche of two co-occurring ophiuroid species in impacted coastal systems, derived from fatty acid and stable isotope analyses. Mar. Ecol. Prog. Ser. 525, 127-141. https://doi.org/10.3354/meps11169

Blanchet-Aurigny, A., Guillou, M., Pernet, F., Gaffet, J.-D., Dubois, S.F., 2012. Tissue-diet discrimination factors of isotopic ratios $\left(\Delta \delta^{13} \mathrm{C}\right.$ and $\left.\Delta \delta^{15} \mathrm{~N}\right)$ in two brittle star species: Effect of reproductive state, diet and tissue composition. Journal of Experimental Marine Biology and Ecology 426-427, 68-77. https://doi.org/10.1016/j.jembe.2012.05.013 
Bougrier, S., Geairon, P., Deslous-Paoli, J.M., Bacher, C., Jonquières, G., 1995. Allometric relationships and effects of temperature on clearance and oxygen consumption rates of Crassostrea gigas (Thunberg). Aquaculture 134, 143-154. https://doi.org/10.1016/0044-8486(95)00036-2

Breton, G., Huriez, L., 2010. Les crépidules Crepidula fornicata (Linnaeus 1758) peuvent temporairement redevenir brouteuses à l'âge adulte. Bulletin de la Société Linnéenne de Normandie 120, 98-104.

Brotas, V., Plante-Cuny, M., 1998. Spatial and temporal patterns of microphytobenthic taxa of estuarine tidal flats in the Tagus Estuary (Portugal) using pigment analysis by HPLC. Mar. Ecol. Prog. Ser. 171, 43-57. https://doi.org/10.3354/meps 171043

Brotas, V., Plante-Cuny, M.-R., 2003. The use of HPLC pigment analysis to study microphytobenthos communities. Acta Oecologica 24, S109-S115. https://doi.org/10.1016/S1146-609X(03)00013-4

Budge, S.M., Parrish, C.C., 1998. Lipid biogeochemistry of plankton, settling matter and sediments in Trinity Bay, Newfoundland. II. Fatty acids. Organic Geochemistry 29, 1547-1559. https://doi.org/10.1016/S0146-6380(98)00177-6

Canuel, E.A., 2001. Relations between river flow, primary production and fatty acid composition of particulate organic matter in San Francisco and Chesapeake Bays: a multivariate approach. Organic Geochemistry 32, 563-583.

Cartaxana, P., Jesus, B., Brotas, V., 2003. Pheophorbide and pheophytin $a$-like pigments as useful markers for intertidal microphytobenthos grazing by Hydrobia ulvae. Estuarine, Coastal and Shelf Science 58, 293-297. https://doi.org/10.1016/S0272-7714(03)00081-7

Cartaxana, P., Mendes, C.R., van Leeuwe, M.A., Brotas, V., 2006. Comparative study on microphytobenthic pigments of muddy and sandy intertidal sediments of the Tagus estuary. Estuarine, Coastal and Shelf Science 66, 225-230. https://doi.org/10.1016/j.ecss.2005.08.011

Caut, S., Angulo, E., Courchamp, F., 2009. Variation in discrimination factors $\left(\Delta^{15} \mathrm{~N}\right.$ and $\left.\Delta^{13} \mathrm{C}\right)$ : the effect of diet isotopic values and applications for diet reconstruction. Journal of Applied Ecology 46, 443453. https://doi.org/10.1111/j.1365-2664.2009.01620.x

Chaparro, O., Thompson, R., Pereda, S., 2002. Feeding mechanisms in the gastropod Crepidula fecunda. Mar. Ecol. Prog. Ser. 234, 171-181. https://doi.org/10.3354/meps234171

Chaparro, O.R., Bahamondes-Rojas, I., Vergara, A.M., Rivera, A.A., 1998. Histological characteristics of the foot and locomotory activity of Crepidula dilatata Lamarck (Gastropoda: Calyptraeidae) in relation to sex changes. Journal of Experimental Marine Biology and Ecology 223, 77-91. https://doi.org/10.1016/S0022-0981(97)00151-2

Chatterjee, A., Klein, C., Naegelen, A., Claquin, P., Masson, A., Legoff, M., Amice, E., L’Helguen, S., Chauvaud, L., Leynaert, A., 2013. Comparative dynamics of pelagic and benthic micro-algae in a coastal ecosystem. Estuarine, Coastal and Shelf Science 133, 67-77. https://doi.org/10.1016/j.ecss.2013.08.015

Chauvaud, L., Jean, F., Ragueneau, O., Thouzeau, G., 2000. Long-term variation of the Bay of Brest ecosystem: benthic-pelagic coupling revisited. Mar. Ecol. Prog. Ser. 200, 35-48. https://doi.org/10.3354/meps200035

Chu, F.-L.E., Greaves, J., 1991. Metabolism of palmitic, linoleic, and linolenic acids in adult oysters, Crassostrea virginica. Mar. Biol. 110, 229-236. https://doi.org/10.1007/BF01313708

Cifuentes, L.A., Fogel, M.L., Pennock, J.R., Sharp, J.H., 1989. Biogeochemical factors that influence the stable nitrogen isotope ratio of dissolved ammonium in the Delaware Estuary. Geochimica et Cosmochimica Acta 53, 2713-2721. https://doi.org/10.1016/0016-7037(89)90142-7

Coe, W.R., 1936. Sexual phases in Crepidula. J. Exp. Zool. 72, 455-477. https://doi.org/10.1002/jez.1400720306

Connelly, T., McClelland, J., Crump, B., Kellogg, C., Dunton, K., 2015. Seasonal changes in quantity and composition of suspended particulate organic matter in lagoons of the Alaskan Beaufort Sea. Mar. Ecol. Prog. Ser. 527, 31-45. https://doi.org/10.3354/meps11207

Connelly, T.L., Businski, T.N., Deibel, D., Parrish, C.C., Trela, P., 2016. Annual cycle and spatial trends in fatty acid composition of suspended particulate organic matter across the Beaufort Sea shelf. Estuarine, Coastal and Shelf Science 181, 170-181. https://doi.org/10.1016/j.ecss.2016.08.016

Correia, A.D., Costa, M.H., Luis, O.J., Livingstone, D.R., 2003. Age-related changes in antioxidant enzyme activities, fatty acid composition and lipid peroxidation in whole body Gammarus locusta (Crustacea: Amphipoda). Journal of Experimental Marine Biology and Ecology 289, 83-101. https://doi.org/10.1016/S0022-0981(03)00040-6 
Cresson, P., Ruitton, S., Harmelin-Vivien, M., 2016. Feeding strategies of co-occurring suspension feeders in an oligotrophic environment. Food Webs 6, 19-28. https://doi.org/10.1016/j.fooweb.2015.12.002 Cugier, P., Struski, C., Blanchard, M., Mazurié, J., Pouvreau, S., Olivier, F., Trigui, J.R., Thiébaut, E., 2010. Assessing the role of benthic filter feeders on phytoplankton production in a shellfish farming site: Mont Saint Michel Bay, France. Journal of Marine Systems 82, 21-34. https://doi.org/10.1016/j.jmarsys.2010.02.013

Dagorn, F., Buzin, F., Couzinet-Mossion, A., Decottignies, P., Viau, M., Rabesaotra, V., Barnathan, G., Wielgosz-Collin, G., 2014. Multiple beneficial lipids including lecithin detected in the edible invasive mollusk Crepidula fornicata from the French Northeastern Atlantic coast. Marine Drugs 12, 6254-6268. https://doi.org/10.3390/md12126254

Dalsgaard, J., St. John, M., Kattner, G., Müller-Navarra, D., Hagen, W., 2003. Fatty acid trophic markers in the pelagic marine environment. Advances in Marine Biology 46, 225-340. https://doi.org/10.1016/S0065-2881(03)46005-7

de Montaudouin, X., Accolla, C., 2018. Intraspecific trade-offs between facilitation and competition in the invasive mollusc Crepidula fornicata. Mar. Ecol. Prog. Ser. 604, 163-171. https://doi.org/10.3354/meps12726

Decottignies, P, Beninger, P., Rincé, Y., Robins, R., Riera, P., 2007. Exploitation of natural food sources by two sympatric, invasive suspension-feeders: Crassostrea gigas and Crepidula fornicata. Mar. Ecol. Prog. Ser. 334, 179-192. https://doi.org/10.3354/meps334179

Decottignies, Priscilla, Beninger, P.G., Rincé, Y., Riera, P., 2007. Trophic interactions between two introduced suspension-feeders, Crepidula fornicata and Crassostrea gigas, are influenced by seasonal effects and qualitative selection capacity. Journal of Experimental Marine Biology and Ecology 342, 231-241. https://doi.org/10.1016/j.jembe.2006.10.005

DeNiro, M., Epstein, S., 1981. Influence of diet on the distribution of nitrogen isotopes in animals. Geochimica et Cosmochimica Acta 45, 341-351.

Deslous-Paoli, J., Héral, M., 1986. Crepidula fornicata L. (Gastéropode, Calyptraeidae) dans le bassin de Marennes-Oléron : composition et valeur énergétique des individus et des pontes. Oceanologica acta 9, 305-311.

Diederich, C., Bashevkin, S., Chaparro, O., Pechenik, J., 2015. Desiccation tolerance and lifting behavior in Crepidula fornicata (Gastropoda). Mar. Ecol. Prog. Ser. 528, 235-243. https://doi.org/10.3354/meps11284

Dubois, S., Blanchet, H., Garcia, A., Massé, M., Galois, R., Grémare, A., Charlier, K., Guillou, G., Richard, P., Savoye, N., 2014. Trophic resource use by macrozoobenthic primary consumers within a semienclosed coastal ecosystem: Stable isotope and fatty acid assessment. Journal of Sea Research 88, 87-99. https://doi.org/10.1016/j.seares.2014.01.004

Dubois, S.F., Colombo, F., 2014. How picky can you be? Temporal variations in trophic niches of cooccurring suspension-feeding species. Food Webs 1, 1-9. https://doi.org/10.1016/j.fooweb.2014.07.001

Dunstan, G.A., Volkman, J.K., Jeffrey, S.W., Barrett, S.M., 1992. Biochemical composition of microalgae from the green algal classes Chlorophyceae and Prasinophyceae. 2. Lipid classes and fatty acids. Journal of Experimental Marine Biology and Ecology 161, 115-134. https://doi.org/10.1016/00220981(92)90193-E

Fleurence, J., Gutbier, G., Mabeau, S., Leray, C., 1994. Fatty acids from 11 marine macroalgae of the French Brittany coast. J Appl Phycol 6, 527-532. https://doi.org/10.1007/BF02182406

Fry, B., Sherr, E.B., 1984. $\delta^{13} \mathrm{C}$ measurements as indicators of carbon flow in marine and freshwater ecosystems. Contributions in Marine Science 27, 13-47.

Guérin, L., 2004. La crépidule en rade de Brest : un modèle biologique d'espèce introduite proliférante en réponse aux fluctuations de l'environnement. Université de Bretagne Occidentale, Brest.

Haack, S.K., Garchow, H., Odelson, D.A., Forney, L.J., Klug, M.J., 1994. Accuracy, reproducibility, and interpretation of fatty acid methyl ester profiles of kodel bacterial communities. Applied and Environmental Microbiology 60, 2483-2493.

Hentschel, B.T., 1998. Intraspecific variation in $\delta^{13} \mathrm{C}$ indicate ontogenic diet changes in deposit-feeding polychaetes. $\quad$ Ecology $79, \quad 1357-1370 . \quad$ https://doi.org/10.1890/00129658(1998)079[1357:IVICIO]2.0.CO;2

Hoagland, K.E., 1978. Protandry and the evolution of environmentally mediated sex change: study of the Mollusca. Malacogia 17, 365-391. 
Hubas, C., Boeuf, D., Jesus, B., Thiney, N., Bozec, Y., Jeanthon, C., 2017. A nanoscale study of carbon and nitrogen fluxes in mats of purple sulfur bacteria: Implications for carbon cycling at the surface of coastal sediments. Front. Microbiol. 8, 1995. https://doi.org/10.3389/fmicb.2017.01995

Jaschinski, S., Brepohl, D., Sommer, U., 2011. Seasonal variation in carbon sources of -mesograzers and small predators in an eelgrass community: stable isotope and fatty acid analyses. Mar. Ecol. Prog. Ser. 431, 69-82. https://doi.org/10.3354/meps09143

Ke, Z., Tan, Y., Huang, L., Zhao, C., Jiang, X., 2017. Spatial distributions of $\delta^{13} \mathrm{C}, \delta^{15} \mathrm{~N}$ and $\mathrm{C} / \mathrm{N}$ ratios in suspended particulate organic matter of a bay under serious anthropogenic influences: Daya Bay, China. Marine Pollution Bulletin 114, 183-191.

Kelly, J.R., Scheibling, R.E., 2012. Fatty acids as dietary tracers in benthic food webs. Mar. Ecol. Prog. Ser. 446, 1-22. https://doi.org/10.3354/meps09559

Kopp, D., Lefebvre, S., Cachera, M., Villanueva, M.C., Ernande, B., 2015. Reorganization of a marine trophic network along an inshore-offshore gradient due to stronger pelagic-benthic coupling in coastal areas. Progress in Oceanography 130, 157-171. https://doi.org/10.1016/j.pocean.2014.11.001

Langdon, C.J., Waldock, M.J., 1981. The effect of algal and artificial diets on the growth and fatty acid composition of Crassostrea gigas Spat. J. Mar. Biol. Ass. 61, 431-448. https://doi.org/10.1017/S0025315400047056

Lavaud, R., Artigaud, S., Le Grand, F., Donval, A., Soudant, P., Flye-Sainte-Marie, J., Strohmeier, T., Strand, Ø., Leynaert, A., Beker, B., Chatterjee, A., Jean, F., 2018. New insights into the seasonal feeding ecology of Pecten maximus using pigments, fatty acids and sterols analyses. Mar. Ecol. Prog. Ser. 590, 109-129. https://doi.org/10.3354/meps 12476

Layman, C.A., Araujo, M.S., Boucek, R., Hammerschlag-Peyer, C.M., Harrison, E., Jud, Z.R., Matich, P., Rosenblatt, A.E., Vaudo, J.J., Yeager, L.A., Post, D.M., Bearhop, S., 2012. Applying stable isotopes to examine food-web structure: an overview of analytical tools. Biological Reviews 87, 545-562. https://doi.org/10.1111/j.1469-185X.2011.00208.x

Le Grand, F., Soudant, P., Siah, A., Tremblay, R., Marty, Y., Kraffe, E., 2014. Disseminated neoplasia in the soft-shell clam Mya arenaria: membrane lipid composition and functional parameters of circulating cells. Lipids 49, 807-818. https://doi.org/10.1007/s11745-014-3917-4

Lefebvre, S., Dubois, S.F., 2016. The stony road to understand isotopic enrichment and turnover rates: insight into the metabolic part. Vie et Milieu 66, 306-315.

Lefebvre, S., Marín Leal, J.C., Dubois, S., Orvain, F., Blin, J.-L., Bataillé, M.-P., Ourry, A., Galois, R., 2009. Seasonal dynamics of trophic relationships among co-occurring suspension-feeders in two shellfish culture dominated ecosystems. Estuarine, Coastal and Shelf Science 82, 415-425. https://doi.org/10.1016/j.ecss.2009.02.002

Leroy, F., Meziane, T., Riera, P., Comtet, T., 2013. Seasonal variations in maternal provisioning of Crepidula fornicata (Gastropoda): fatty acid composition of females, embryos and larvae. PLoS ONE 8, e75316. https://doi.org/10.1371/journal.pone.0075316

Liénart, C., Savoye, N., Bozec, Y., Breton, E., Conan, P., David, V., Feunteun, E., Grangeré, K., Kerhervé, P., Lebreton, B., Lefebvre, S., L’Helguen, S., Mousseau, L., Raimbault, P., Richard, P., Riera, P., Sauriau, P.-G., Schaal, G., Aubert, F., Aubin, S., Bichon, S., Boinet, C., Bourasseau, L., Bréret, M., Caparros, J., Cariou, T., Charlier, K., Claquin, P., Cornille, V., Corre, A.-M., Costes, L., Crispi, O., Crouvoisier, M., Czamanski, M., Del Amo, Y., Derriennic, H., Dindinaud, F., Durozier, M., Hanquiez, V., Nowaczyk, A., Devesa, J., Ferreira, S., Fornier, M., Garcia, F., Garcia, N., Geslin, S., Grossteffan, E., Gueux, A., Guillaudeau, J., Guillou, G., Joly, O., Lachaussée, N., Lafont, M., Lamoureux, J., Lecuyer, E., Lehodey, J.-P., Lemeille, D., Leroux, C., Macé, E., Maria, E., Pineau, P., Petit, F., Pujo-Pay, M., Rimelin-Maury, P., Sultan, E., 2017. Dynamics of particulate organic matter composition in coastal systems: A spatio-temporal study at multi-systems scale. Progress in Oceanography 156, 221-239. https://doi.org/10.1016/j.pocean.2017.03.001

Lorrain, A., Savoye, N., Chauvaud, L., Paulet, Y.-M., Naulet, N., 2003. Decarbonation and preservation method for the analysis of organic $\mathrm{C}$ and $\mathrm{N}$ contents and stable isotope ratios of low-carbonated suspended particulate material. Analytica Chimica Acta 491, 125-133. https://doi.org/10.1016/S0003-2670(03)00815-8

Majdi, N., Hette-Tronquart, N., Auclair, E., Bec, A., Chouvelon, T., Cognie, B., Danger, M., Decottignies, P., Dessier, A., Desvilettes, C., Dubois, S., Dupuy, C., Fritsch, C., Gaucherel, C., Hedde, M., Jabot, F., Lefebvre, S., Marzloff, M.P., Pey, B., Peyrard, N., Powolny, T., Sabbadin, R., Thébault, E., 
Perga, M.-E., 2018. There's no harm in having too much: A comprehensive toolbox of methods in trophic ecology. Food Webs 17, e00100. https://doi.org/10.1016/j.fooweb.2018.e00100

Marchais, V., Schaal, G., Grall, J., Lorrain, A., Nerot, C., Richard, P., Chauvaud, L., 2013. Spatial variability of stable isotope ratios in oysters (Crassostrea gigas) and primary producers along an estuarine gradient (Bay of Brest, France). Estuaries and Coasts 36, 808-819. https://doi.org/10.1007/s12237012-9584-x

Martin, S., Thouzeau, G., Chauvaud, L., Jean, F., Guérin, L., Clavier, J., 2006. Respiration, calcification, and excretion of the invasive slipper limpet, Crepidula fornicata L.: Implications for carbon, carbonate, and nitrogen fluxes in affected areas. Limnol. Oceanogr. 51, 1996-2007. https://doi.org/10.4319/lo.2006.51.5.1996

Martinez Arbizu, P., 2017. pairwiseAdonis: Pairwise multilevel comparison using adonis. R package version 0.3 .

McCutchan, J.H.J., Lewis, W.M.J., Kendall, C., McGrath, C.C., 2003. Variation in trophic shift for stable isotope ratios of carbon, nitrogen, and sulfur. Oikos 102, 378-390.

McGee, D., Laws, R., Cahoon, L., 2008. Live benthic diatoms from the upper continental slope: extending the limits of marine primary production. Mar. Ecol. Prog. Ser. 356, 103-112. https://doi.org/10.3354/meps07280

Meziane, T., Bodineau, L., Retiere, C., Thoumelin, G., 1997. The use of lipid markers to define sources of organic matter in sediment and food web of the intertidal salt-marsh-flat ecosystem of Mont-SaintMichel Bay, France. Journal of Sea Research 38, 47-58. https://doi.org/10.1016/S13851101(97)00035-X

Mineur, F., Belsher, T., Johnson, M.P., Maggs, C.A., Verlaque, M., 2007. Experimental assessment of oyster transfers as a vector for macroalgal introductions. Biological Conservation 137, 237-247. https://doi.org/10.1016/j.biocon.2007.02.001

Montiel, Y.A., Chaparro, O.R., Segura, C.J., 2005. Changes in feeding mechanisms during early ontogeny in juveniles of Crepidula fecunda (Gastropoda, Calyptraeidae). Marine Biology 147, 1333-1342. https://doi.org/10.1007/s00227-005-0050-1

Mortillaro, J.M., Schaal, G., Grall, J., Nerot, C., Brind'Amour, A., Marchais, V., Perdriau, M., Le Bris, H., 2014. Comparative study of isotopic trends in two coastal ecosystems of North Biscay: A multitrophic spatial gradient approach. Estuarine, Coastal and Shelf Science 136, 149-156. https://doi.org/10.1016/j.ecss.2013.11.025

Napolitano, G.E., Pollero, R.J., Gayoso, A.M., Macdonald, B.A., Thompson, R.J., 1997. Fatty acids as trophic markers of phytoplankton blooms in the Bahía Blanca estuary (Buenos Aires, Argentina) and in Trinity Bay (Newfoundland, Canada). Biochemical Systematics and Ecology 25, 739-755. https://doi.org/10.1016/S0305-1978(97)00053-7

Navarro, J.M., Chaparro, O.R., 2002. Grazing-filtration as feeding mechanisms in motile specimens of Crepidula fecunda (Gastropoda: Calyptraeidae). Journal of Experimental Marine Biology and Ecology 270, 111-122. https://doi.org/10.1016/S0022-0981(02)00013-8

Ní Longphuirt, S., Clavier, J., Grall, J., Chauvaud, L., Le Loc'h, F., Le Berre, I., Flye-Sainte-Marie, J., Richard, J., Leynaert, A., 2007. Primary production and spatial distribution of subtidal microphytobenthos in a temperate coastal system, the Bay of Brest, France. Estuarine, Coastal and Shelf Science 74, 367-380. https://doi.org/10.1016/j.ecss.2007.04.025

Parrish, C., Thompson, R., Deibel, D., 2005. Lipid classes and fatty acids in plankton and settling matter during the spring bloom in a cold ocean coastal environment. Mar. Ecol. Prog. Ser. 286, 57-68. https://doi.org/10.3354/meps286057

Passarelli, C., Hubas, C., Nicolas Segui, A., Grange, J., Meziane, T., 2012. Surface adhesion of microphytobenthic biofilms is enhanced under Hediste diversicolor (O.F. Müller) trophic pressure. Journal of Experimental Marine Biology and Ecology 438, 52-60. https://doi.org/10.1016/j.jembe.2012.10.005

Pernet, F., Malet, N., Pastoureaud, A., Vaquer, A., Quéré, C., Dubroca, L., 2012. Marine diatoms sustain growth of bivalves in a Mediterranean lagoon. Journal of Sea Research 68, 20-32. https://doi.org/10.1016/j.seares.2011.11.004

Pernet, F., Tremblay, R., 2004. Effect of varying levels of dietary essential fatty acid during early ontogeny of the sea scallop Placopecten magellanicus. Journal of Experimental Marine Biology and Ecology 310, 73-86. https://doi.org/10.1016/j.jembe.2004.04.001 
Pernet, F., Tremblay, R., Comeau, L., Guderley, H., 2007. Temperature adaptation in two bivalve species from different thermal habitats: energetics and remodelling of membrane lipids. Journal of Experimental Biology 210, 2999-3014. https://doi.org/10.1242/jeb.006007

Perry, G.J., Volkman, J.K., Johns, R.B., Bavor, H.J., 1979. Fatty acids of bacterial origin in contemporary marine sediments. Geochimica et Cosmochimica Acta 43, 1715-1725. https://doi.org/10.1016/0016-7037(79)90020-6

Prins, T.C., Smaal, A.C., Dame, R.F., 1998. A review of the feedbacks between bivalve grazing and ecosystem processes. Aquatic Ecology 31, 349-359.

R Core Team, 2012. R: A language and environment for statistical computing.

Ragueneau, O., Chauvaud, L., Leynaert, A., Thouzeau, G., Paulet, Y.-M., Bonnet, S., Lorrain, A., Grall, J., Corvaisier, R., Hir, M.L., Jean, F., Clavier, J., 2002. Direct evidence of a biologically active Coastal Silicate pump: ecological implications. Limnology and Oceanography 47, 1849-1854.

Ragueneau, O., Raimonet, M., Mazé, C., Coston-Guarini, J., Chauvaud, L., Danto, A., Grall, J., Jean, F., Paulet, Y.-M., Thouzeau, G., 2018. The impossible sustainability of the Bay of Brest? Fifty years of ecosystem changes, Interdisciplinary knowledge construction and key questions at the sciencepolicy-community interface. Front. Mar. Sci. 5. https://doi.org/10.3389/fmars.2018.00124

Raimonet, M., Andrieux-Loyer, F., Ragueneau, O., Michaud, E., Kerouel, R., Philippon, X., Nonent, M., Mémery, L., 2013. Strong gradient of benthic biogeochemical processes along a macrotidal temperate estuary: focus on $\mathrm{P}$ and $\mathrm{Si}$ cycles. Biogeochemistry 115, 399-417. https://doi.org/10.1007/s10533-013-9843-3

Riera, P., 2007. Trophic subsidies of Crassostrea gigas, Mytilus edulis and Crepidula fornicata in the Bay of Mont Saint Michel (France): $\mathrm{A} \delta^{13} \mathrm{C}$ and $\delta^{15} \mathrm{~N}$ investigation. Estuarine, Coastal and Shelf Science 72, 33-41. https://doi.org/10.1016/j.ecss.2006.10.002

Riera, P., Stal, L., Nieuwenhuize, J., 2002. $\delta^{13} \mathrm{C}$ versus $\delta^{15} \mathrm{~N}$ of co-occurring molluscs within a community dominated by Crassostrea gigas and Crepidula fornicata (Oosterschelde, The Netherlands). Mar. Ecol. Prog. Ser. 240, 291-295. https://doi.org/10.3354/meps240291

Rigolet, C., Thiébaut, E., Dubois, S., 2014. Food web structures of subtidal benthic muddy habitats: evidence of microphytobenthos contribution supported by an engineer species. Mar. Ecol. Prog. Ser. 500, 2541. https://doi.org/10.3354/meps10685

Rossi, F., Herman, P.M.J., Middelburg, J.J., 2004. Interspecific and intraspecific variation of $\delta^{13} \mathrm{C}$ and $\delta^{15} \mathrm{~N}$ in deposit- and suspension-feeding bivalves (Macoma balthica and Cerastoderma edule): Evidence of ontogenetic changes in feeding mode of Macoma balthica. Limnol. Oceanogr. 49, 408-414. https://doi.org/10.4319/lo.2004.49.2.0408

Roy, S., Llewellyn, C.A., Egeland, E.S., Johnsen, G., 2011. Phytoplankton Pigments, Characterization, Chemotaxonomy, and Applications in Oceanography, Cambridge University Press. ed. Cambridge, UK.

Shumway, S.E., Ward, J.E., Heupel, E., Holohan, B.A., Heupel, J., Heupel, T., Padilla, D.K., 2014. Observations of feeding in the common Atlantic slippersnail Crepidula fornicata L., with special reference to the "mucus net." Journal of Shellfish Research 33, 279-291. https://doi.org/10.2983/035.033.0127

Tremblay, R., Olivier, F., Bourget, E., Rittschof, D., 2007. Physiological condition of Balanus amphitrite cyprid larvae determines habitat selection success. Mar. Ecol. Prog. Ser. 340, 1-8. https://doi.org/10.3354/meps340001

Vander Zanden, M.J., Clayton, M.K., Moody, E.K., Solomon, C.T., Weidel, B.C., 2015. Stable isotope turnover and half-life in animal tissues: a literature synthesis. PLoS ONE 10, e0116182. https://doi.org/10.1371/journal.pone.0116182

Wainright, S.C., Fry, B., 1994. Seasonal variation of the stable isotopic compositions of coastal marine plankton from Woods Hole, Massachusetts and Georges Bank. Estuaries 17, 552. https://doi.org/10.2307/1352403

Walne, P.R., 1956. The biology and distribution of the slipper limpet Crepidula fornicata in Essex rivers. Fishery Investigations Series II 20, 1-50.

Yee, A.K., Padilla, D.K., 2015. Allometric scaling of the radula in the Atlantic slippersnail Crepidula fornicata. Journal of Shellfish Research 34, 903-907. https://doi.org/10.2983/035.034.0320

Zhukova, N., Aizdacher, N., 1995. Fatty acid composition of 15 species of marine microalgae. Phytochemistry 39, 351-356. https://doi.org/10.1016/0031-9422(94)00913-E 
bioRxiv preprint doi: https://doi.org/10.1101/2020.07.30.229021; this version posted July 31, 2020. The copyright holder for this preprint (which was not certified by peer review) is the author/funder. All rights reserved. No reuse allowed without permission.

891 Zhukova, N.V., 1991. The pathway of the biosynthesis of non-methylene-interrupted dienoic fatty acids in 892

893

894

895

896

897 molluscs. Comparative Biochemistry and Physiology Part B: Comparative Biochemistry 100, 801804. https://doi.org/10.1016/0305-0491(91)90293-M

Zhukova, N.V., Kharlamenko, V.I., Svetashev, V.I., Rodionov, I.A., 1992. Fatty acids as markers of bacterial symbionts of marine bivalve molluscs. Journal of Experimental Marine Biology and Ecology 162, 253-263. https://doi.org/10.1016/0022-0981(92)90205-O 


\section{Supplementary materials}

Table S1: Pigment (\%, mean \pm SD, $n \geq 2$ ) composition of organic matter sources (Biofilm, suspended particulate organic matter (SPOM), superficial sedimentary organic matter (SSOM)) over the sampling survey. UK: Unknown pigments.

\begin{tabular}{|c|c|c|c|c|c|c|c|c|c|c|c|c|c|c|c|}
\hline \multirow[b]{2}{*}{ Pigments } & \multicolumn{3}{|c|}{ S1 = 26th February } & \multicolumn{3}{|c|}{$\mathrm{S} 2=21$ th March } & \multicolumn{3}{|c|}{$\mathrm{S} 3=28$ th March } & \multicolumn{3}{|c|}{$\mathrm{S} 4=12$ th April } & \multicolumn{3}{|c|}{ S5 $=14$ th June } \\
\hline & iofilm & SPOM & SOM & iofilm & SPOM & SSOM & iofilm & SPOM & SSOM & iofilm & SPOM & SSOM & Biofilm & SPOM & SSOM \\
\hline Alloxanthin & \pm 2.2 & $11.7 \pm 1.3$ & $3.9 \pm$ & $2 \pm 0.8$ & $7.1 \pm 1.2$ & & \pm 1 & $9.3 \pm 0.3$ & 3.3 & 0.2 & $5.1 \pm 0.8$ & 4.1 & \pm 0.6 & 1.3 & 0.4 \\
\hline$\beta c$ & $8 \pm 0.6$ & $0 \pm 0$ & $7 \pm 0.2$ & \pm 0.1 & $0.3 \pm 0.2$ & 0 & 0.1 & .1 & 0 & 0.9 & $3.2 \pm 3.4$ & 0 & 0.5 & 0.5 & 1.6 \\
\hline Chlor & $4.7 \pm 0.6$ & $7.7 \pm 1.4$ & $0.8 \pm 0.2$ & $4.1 \pm 0.4$ & $6.1 \pm 0.7$ & $0.3 \pm 0.1$ & \pm 0.4 & 7.2 & 0.4 & $=0.6$ & \pm 0.6 & 0.3 & 0.4 & 0.1 & $=0.1$ \\
\hline Chlo & $19.8 \pm 1.7$ & $7.8 \pm 0.7$ & $0.6 \pm 0.1$ & 2 & 84 & 0.3 & \pm 0.1 & .1 & 0.3 & \pm 2.9 & .6 & 0.2 & 0.6 & & $=0.2$ \\
\hline Chlor & $0.3 \pm 0.1$ & $0 \pm 0$ & $0.1 \pm 0$ & $0.3 \pm 0.3$ & $0.1 \pm 0.1$ & $.1 \pm 0$ & \pm 0.1 & $0.2 \pm 0$ & $0.1 \pm 0$ & \pm 0.4 & $0.3 \pm 0.1$ & 0.1 & \pm 0.1 & $0.2 \pm 0$ & \pm 0 \\
\hline Diac & $0.8 \pm 0.1$ & $2.7 \pm 0.4$ & $1.1 \pm 0.1$ & $0.6 \pm 0.1$ & $3.4 \pm 0.2$ & .1 & $7 \pm 0.1$ & \pm 0 & 0.9 & \pm 0.1 & \pm 0.1 & 1.4 & $1 \pm 0$ & \pm 0 & 0.2 \\
\hline Xan & $1.1 \pm 0$ & $2.5 \pm 0.1$ & $3.5 \pm 0.2$ & $0 \pm 0$ & $1.8 \pm 1.6$ & 2.9 & \pm 0.1 & 0.1 & 3.3 & $0.7 \pm 0.2$ & $2.1 \pm 0.2$ & 3.1 & \pm 0.1 & 0.2 & \pm 0.5 \\
\hline -like & $1.1 \pm 0.1$ & $2.7 \pm 0.2$ & $4.2 \pm 0.4$ & $1.2 \pm 0.1$ & $3.5 \pm 0.1$ & $5.6 \pm 0.8$ & $1.4 \pm 0.4$ & $4 \pm 0.3$ & $5.1 \pm 0.2$ & $2.8 \pm 1.9$ & $3 \pm 0.1$ & $5.7 \pm 0.6$ & \pm 0.2 & \pm 0.1 & \pm 0.5 \\
\hline Fuc & $12.5 \pm 2.8$ & $22.5 \pm 1.8$ & $5.8 \pm 0.9$ & $10.8 \pm 2.4$ & $421.5 \pm 1.4$ & $5 \pm 1.2$ & $2.2 \pm 3.4$ & 19.2 & $6.1 \pm 1.3$ & $12.3 \pm 1.3$ & 0.9 & $6.8 \pm 0.3$ & $16.1 \pm 2.3$ & & \pm 1.1 \\
\hline Pheo & 14.8 & 2 & 32 & 6 & 3 & .6 & & & & & & & 1.1 & & 1.1 \\
\hline Lute & \pm 0.1 & .8 & 13.9 & 5 & .7 & 1 & .3 & .4 & 1 & 0.3 & 0.6 & 8 & 0.1 & 0 & 1.5 \\
\hline $\mathrm{Ne}$ & $7.7 \pm 1.2$ & $1.7 \pm 0.2$ & $0 \pm 0$ & $14.8 \pm 0.7$ & $2.7 \pm 0.4$ & $0 \pm 0$ & $2.9 \pm 0.5$ & $5.1 \pm 0.2$ & $0 \pm 0$ & $1 \pm 4.3$ & $2.1 \pm 0.1$ & $2.9 \pm 0.1$ & $2 \pm 0.9$ & $2 \pm 0.2$ & $0.7 \pm 1.2$ \\
\hline $\mathrm{Ph}$ & $4.1 \pm 3.3$ & $0 \pm 0$ & $23.2 \pm 1.1$ & $1 \pm 0.7$ & $0.8 \pm 1.4$ & $32.9 \pm 2.4$ & $2.9 \pm 0.6$ & $1.3 \pm 0.1$ & $31.1 \pm 1.8$ & $7.9 \pm 1.4$ & $9.5 \pm 5.8$ & $30.1 \pm 1.9$ & $15 \pm 1.5$ & 17. & \pm 2.6 \\
\hline Chlc & $1.5 \pm 0.5$ & $4.8 \pm 0.5$ & $3.7 \pm 0.2$ & $0 \pm 0$ & $12.5 \pm 1.5$ & $6.4 \pm 0.2$ & $1.3 \pm 0.2$ & 15.2 & $7.2 \pm 0.7$ & \pm 0.3 & $6.6 \pm 1$ & $8=$ & \pm 0.1 & 0.3 & $3.9 \pm 0.4$ \\
\hline & $1 \pm 0.3$ & $0.9 \pm 0$ & 0. & 0.2 & .4 & 0 & 0 & .1 & 0 & 0.3 & 0.4 & 1 & \pm 0 & 0.2 & 0.1 \\
\hline UK 6 & 3 & 4 & 0 & 26. & 0 & $0 \pm 0$ & .3 & 0 & 4 & 20 & 0 & 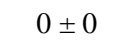 & 0.9 & 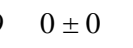 & 0 \\
\hline UK 7 & $1.2 \pm 0.1$ & $0 \pm 0$ & $0 \pm 0$ & $1.7 \pm 0.1$ & $0 \pm 0$ & $0 \pm 0$ & $1.1 \pm 0.3$ & $0 \pm 0$ & $0 \pm 0$ & \pm 0.1 & $0 \pm 0$ & $0 \pm 0$ & $0.9 \pm 0$ & $0 \pm 0$ & \pm 0 \\
\hline & $0.6 \pm 0.1$ & $0 \pm 0$ & $0 \pm 0$ & $1.1 \pm 0.6$ & $0 \pm 0$ & $0 \pm 0$ & $1 \pm 0.8$ & $0 \pm 0$ & $0 \pm 0$ & $0.7 \pm 0.6$ & $0 \pm 0$ & $0 \pm 0$ & $1.3 \pm 0.5$ & $0 \pm 0$ & $0 \pm 0$ \\
\hline 9 & $0 \pm 0$ & $0 \pm 0$ & $0 \pm 0$ & $0 \pm 0$ & $0 \pm 0$ & $0 \pm 0$ & $0 \pm 0$ & $0 \pm 0$ & $0 \pm 0$ & $0 \pm 0$ & $0.8 \pm 0.3$ & $0 \pm 0$ & $0 \pm 0$ & $0.8 \pm 0$ & $0.2 \pm 0.2$ \\
\hline Violaxa & $0.6 \pm 0.2$ & $1.3 \pm 0.3$ & $0 \perp 0$ & $0 \pm 0$ & $0.7 \pm 0.7$ & $0 \pm 0$ & $0.9 \pm 0.1$ & $3.3 \pm 0.4$ & $0 \pm 0$ & $0.3 \pm 0.5$ & $1.8 \pm 1.7$ & $0 \leq 0$ & $0.2 \pm 0.4$ & $4.5 \pm 0.1$ & $0 \pm 0$ \\
\hline in & $2 \pm 0.1$ & $5.2 \pm 0.2$ & $5 \pm 0.5$ & $0.8 \pm 0.4$ & $2.5 \pm 0.4$ & $4.8 \pm 1.1$ & $1.6 \pm 0$ & $1.7 \pm 0.1$ & $4.2 \pm 0.3$ & $1.1 \pm 0$ & $3.2 \pm 0.3$ & $3.7 \pm 0.6$ & $0.9 \pm 0.1$ & $2.3 \pm 0.1$ & $1.9 \pm 0.6$ \\
\hline hl $c$ / Chl $a$ rati & $0.3 \pm 0.1$ & $0.6 \pm 0.2$ & $4.5 \pm 0.7$ & $0 \pm 0$ & $2.1 \pm 0.52$ & $27.3 \pm 17.1$ & $0.3 \pm 0.1$ & $2.1 \pm 0$ & $17.1 \pm 1.2$ & $0.3 \pm 0.1$ & $1.1 \pm 0.1$ & $28 \pm 14.9$ & $0.4 \pm 0.1$ & $0.9 \pm 0$ & $5.8 \pm 1.1$ \\
\hline al $b$ / Chl $a$ rati & & 0.1 & $0.7 \pm 0.1$ & $6.3 \pm 0.7$ & $0.8 \pm 0$ & $2 \pm 0.5$ & $5.3 \pm 0.5$ & $1 \pm 0$ & $0.7 \pm 0.2$ & $4.2 \pm 0.6$ & $0.7 \pm 0$ & $0.6 \pm 0$ & $3.2 \pm 0.4$ & \pm 0 & $0.5 \pm 0.3$ \\
\hline uco / Chl $a$ ratio & $2.6 \pm 0.3$ & $3 \pm 0.8$ & $7 \pm 1.7$ & $2.6 \pm 0.6$ & $3.6 \pm 0.6$ & $19.3 \pm 6.7$ & $2.9 \pm 0.6$ & $2.7 \pm 0$ & $14.5 \pm 3.2$ & $2.7 \pm 0.5$ & $3.5 \pm 0.4$ & $23 \pm 9.8$ & $3.2 \pm 0.2$ & $2.4 \pm 0.1$ & $6.3 \pm 1.4$ \\
\hline
\end{tabular}


Table S2: Fatty acid (FA) (\%, mean \pm SD, $n=3$ ) composition of organic matter sources (Biofilm, suspended particulate organic matter (SPOM), superficial sedimentary organic matter (SSOM)) over the sampling survey. Only FA accounting for more than $0.5 \%$ of total FA in at least one sample was shown. 904 BFA: Branched FA; SFA: saturated FA; MUFA: monounsaturated FA; PUFA: polyunsaturated FA; UK FA: Unknown FA; EPA: 20:5n-3; DHA: 22:6n9053.

\begin{tabular}{|c|c|c|c|c|c|c|c|c|c|c|c|c|c|c|c|}
\hline \multirow[b]{2}{*}{ Fatty acids } & \multicolumn{3}{|c|}{$\mathrm{S} 1=26^{\text {th }}$ February } & \multicolumn{3}{|c|}{$\mathrm{S} 2=21^{\text {th }}$ March } & \multicolumn{3}{|c|}{$\mathrm{S} 3=28^{\text {th }}$ March } & \multicolumn{3}{|c|}{$\mathrm{S} 4=12^{\text {th }}$ April } & \multicolumn{3}{|c|}{$\mathrm{S} 5=14^{\text {th }}$ June } \\
\hline & iofilm & SPOM & SSOM & iofilm & SPOM & SSOM & ofilm & SPOM & SSOM & ofilm & SPOM & SSOM & iofilm & SPOM & SSOM \\
\hline TMTD & \pm 0.1 & \pm 0 & & $=0.1$ & & $6 \pm 0$ & 0.1 & \pm 0 & 0.2 & $=0$ & \pm 0 & & \pm 0 & & $0 \pm 0$ \\
\hline 15:0iso & \pm 0.7 & & & & & & & & & & 0.2 & & & & \\
\hline 15:0ant & $0.6 \pm 0.1$ & $2 \pm 0.1$ & \pm 0.7 & \pm 0.1 & $0.9 \pm 0.1$ & $2.9 \pm 0.6$ & \pm 0.2 & \pm 0.1 & 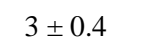 & \pm 0.2 & $1.1 \pm 0.2$ & $3.2 \pm 0.3$ & \pm 0.2 & \pm 0.3 & $2.3 \pm 0.8$ \\
\hline 16:0iso & $0.8 \pm 0.2$ & $9 \pm 0.2$ & $3 \pm 0.4$ & $2 \pm 0$ & $5 \pm 0$ & $0.9 \pm 0.1$ & $5 \pm 0.2$ & $0.5 \pm 0$ & $.8 \pm 0.2$ & \pm 0.2 & $0.5 \pm 0.1$ & $0.9 \pm 0.1$ & $.6 \pm 0.1$ & \pm 0.1 & $0.5 \pm 0.4$ \\
\hline 17:0iso & $0.9 \pm 0.3$ & $7 \pm 0.2$ & $1.4 \pm 0.2$ & \pm 0.1 & $0.3 \pm 0.1$ & $1.2 \pm 0.1$ & $5 \pm 0.4$ & $2.8 \pm 0.1$ & $1.2 \pm 0.1$ & $8 \pm 0.5$ & $2.7 \pm 0.2$ & $1.6 \pm 0.1$ & $.8 \pm 0.6$ & $0.8 \pm 0.5$ & $0.7 \pm 0.6$ \\
\hline 17:0ant & $2.5 \pm 2.4$ & $3 \pm 0.3$ & 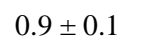 & \pm 0.6 & \pm 0 & $1.1-0.1$ & $6 \pm 0.8$ & -0 & $-\infty$ & $1.6 \pm 0.5$ & $0 \pm 0$ & $0.2 \pm 0.2$ & $1.2 \pm 0.2$ & $0.6 \pm 0.1$ & $0.9 \pm 0.8$ \\
\hline 18:0iso & \pm 0.1 & $2 \pm 0.9$ & \pm 0.2 & \pm 0.1 & $4 \pm 0$ & $0.6 \pm 0.1$ & \pm 0.1 & $0.9 \pm 0.2$ & $0.4 \pm 0.1$ & $4 \pm 0.3$ & $0.9 \pm 0.3$ & $0.6 \pm 0.1$ & $1.7 \pm 0.4$ & & $1.7 \pm 0.4$ \\
\hline$\sum \mathrm{BFA}$ & \pm 2.4 & $6.3 \pm 0.3$ & 12 & $2.2 \pm 0.2$ & $4.4 \pm 0.1$ & \pm 1.6 & \pm 0.7 & $6.2 \pm 0.4$ & $8 \pm 0.7$ & & $6.6 \pm 0.9$ & $9 \pm 0.4$ & & $=0.3$ & $8.1 \pm 1.5$ \\
\hline & $3.1 \pm 0.3$ & $3 \pm 1.3$ & - & \pm 0.4 & 5 & & $2 \pm 0.6$ & & & & \pm 1 & & & & 5. \\
\hline $15: 0$ & $0.9 \pm 0.3$ & $2.6 \pm 0.4$ & $5 \pm 0.2$ & $2 \pm 0.1$ & $1.9 \pm 0.1$ & $1.2=$ & $9 \pm 0.2$ & $1.7 \pm 0.1$ & & $0.8 \pm 0.1$ & $1.4 \pm 0.2$ & & $0.7 \pm 0.1$ & $=0.2$ & $0.7 \pm 0.6$ \\
\hline $16: 0$ & $.5 \pm 3.4$ & $33 \pm 4.9$ & $22.4 \pm 3.1$ & $38.6 \pm 0.7$ & $26.3 \pm 2.3$ & $17.6 \pm 1.6$ & $29.5 \pm 4.3$ & $32.7 \pm 1.9$ & $14.8 \pm 1.4$ & $0.5 \pm 4.4$ & $34.1 \pm 2.3$ & 18. & $19.9 \pm 4.6$ & 4.7 & $19.3 \pm 4.3$ \\
\hline $17: 0$ & $1.6 \pm 0.7$ & $1.6 \pm 0.3$ & \pm 0.2 & $0.8 \pm 0.8$ & $0.1 \pm 0$ & $0.9 \pm 0.1$ & $0.8 \pm 0.2$ & $0.9 \pm 0.1$ & $0.8 \pm 0.1$ & $7 \pm 0.1$ & $0.9 \pm 0.1$ & & $1.6 \pm 0.4$ & 0.2 & $1.8 \pm 0.5$ \\
\hline 18:0 & $16.5 \pm 1.3$ & $11.8 \pm 1.7$ & $9.6 \pm 1.3$ & $42.3 \pm 2.6$ & $13.3 \pm 1.4$ & $10.9 \pm 2.5$ & $21.5 \pm 4.8$ & $9.2 \pm 0.7$ & $68+1$ & $.9 \pm 3.8$ & $14.9 \pm 5.3$ & $7.6 \pm 0.3$ & $6.7 \pm 2.5$ & $=1.3$ & $8 \pm 2.1$ \\
\hline $20: 0$ & $0.6 \pm 0.1$ & $1.7 \pm 0.1$ & $1.9 \pm 1.7$ & $6 \pm 0$ & $1.3 \pm 0$ & $2.8 \pm 0.3$ & $0.8 \pm 0.2$ & $0.9 \pm 0$ & $2.6 \pm 0.3$ & $.9 \pm 0.1$ & $0.4 \pm 0.7$ & & $1.1 \pm 0.7$ & $0.9 \pm 0.2$ & $2.2 \pm 0.3$ \\
\hline $22: 0$ & $1 \pm 0.1$ & $1.4 \pm 1.2$ & $3.2 \pm 3$ & $0.3 \pm 0.2$ & $1.6 \pm 0$ & $4.4 \pm 0.7$ & $1.1 \pm 0.3$ & $0.7 \pm 0.6$ & $4.5 \pm 0.5$ & $4 \pm 0.4$ & $1.4 \pm 0.3$ & $5.4 \pm 0.3$ & $1.2 \pm 0.9$ & $0.7 \pm 0.1$ & $3.5 \pm 0.8$ \\
\hline $24: 0$ & $1 \pm 0$ & $0 \pm 0$ & $0.5 \pm 0.4$ & $0 \pm 0$ & \pm 0 & $0.1 \pm 0.3$ & $7 \pm 0.3$ & $4.4 \pm 2$ & $6.1 \pm 5.2$ & $0.1 \pm 0.1$ & $0.1 \pm 0.2$ & $0.3 \pm 0.3$ & $1.9 \pm 1.5$ & $1.1 \pm 0.2$ & $4.9 \pm 1.2$ \\
\hline$\sum \mathrm{SFA}$ & $45.3 \pm 4.7$ & $59.4 \pm 7.6$ & $45.4 \pm 3.3$ & $84.2 \pm 2.1$ & $50.3 \pm 3.8$ & $41.4 \pm 3.2$ & $59.6 \pm 9.9$ & $62.4 \pm 1.1$ & $40.7 \pm 7.3$ & $62.3 \pm 7.4$ & $61.8 \pm 5$ & $40.7 \pm 0.5$ & $38.1 \pm 10$ & $40.5 \pm 7$ & $45.7 \pm 8$ \\
\hline $14: 1 n-5$ & $0 \pm 0$ & $0 \pm 0$ & $0 \pm 0$ & $0 \pm 0$ & $0 \pm 0$ & $0 \pm 0$ & $0.1 \pm 0.1$ & $0 \pm 0$ & $0.0 \pm 0.1$ & & $0 \pm 0$ & $0 \pm 0$ & $0.2 \pm 0.3$ & $0.1 \pm 0.1$ & $0 \pm 0$ \\
\hline $16: 1 n-11$ & $0.3 \pm 0.3$ & $0 \pm 0$ & & & & & & $0-0$ & & 0.1 & $=-0$ & $0.6 \pm 0.1$ & $0 \pm 0$ & $0 \pm 0$ & $0 \pm 0$ \\
\hline $16: 1 n-9$ & $0.9 \pm 0.1$ & $1.5 \pm 0.9$ & $0.3 \pm 0.5$ & $0.2 \pm 0.2$ & $2 \pm 0.2$ & $1.2 \pm 0.2$ & $0.6 \pm 0.3$ & $0.4 \pm 0.4$ & $0.7 \pm 0.2$ & $0.9 \pm 0.2$ & $0.5 \pm 0.1$ & $0.9 \pm 0.1$ & $0.5 \pm 0.4$ & $0.8 \pm 0.1$ & $0.5 \pm 0.4$ \\
\hline $16: 1 n-7$ & $3.8 \pm 0.1$ & $1.9 \pm 1.5$ & $5.6 \pm 3$ & $0.8 \pm 0.4$ & $4.5 \pm 0.5$ & $8.8 \pm 0.1$ & $2.7 \pm 1.8$ & $0.9 \pm 0.2$ & $7.3 \pm 2.4$ & $2.5 \pm 1.1$ & $1.6 \pm 0.7$ & $0 \pm 0$ & $7.9 \pm 0.6$ & $3.4 \pm 0.8$ & $9 \pm 1.9$ \\
\hline
\end{tabular}


$16: 1 n-5 \quad 0.5 \pm 0.1 \quad 0.8 \pm 0.1 \quad 0.4 \pm 0.4$

$17: 1 \mathrm{n}-7 \quad 0.1 \pm 0.2 \quad 0.4 \pm 0.1 \quad 0.8 \pm 0.3$

$18: 1 n-11 \quad 0.5 \pm 0.3 \quad 0 \pm 0 \quad 0 \pm 0$

$18: 1 n-9 \quad 1.6 \pm 0.7 \quad 0.3 \pm 0.5 \quad 1.3 \pm 2.3$

18:1n-7 $2 \pm 0.2 \quad 0 \pm 0 \quad 0 \pm 0$

$18: 1 n-5 \quad 0.6 \pm 0.1 \quad 0.1 \pm 0.2 \quad 0 \pm 0$

$20: 1 \mathrm{n}-11 \quad 1.2 \pm 0.4 \quad 1.1 \pm 1.5 \quad 0.3 \pm 0.5$

$20: 1 n-9 \quad 0.3 \pm 0 \quad 0.3 \pm 0.5 \quad 0.3 \pm 0.4$

20:1n-7 $0.6 \pm 0.5 \quad 0 \pm 0 \quad 0 \pm 0$

$22: 1 n-9 \quad 0.2 \pm 0.1 \quad 0 \pm 0 \quad 0.3 \pm 0.6$

$\begin{array}{llll}\sum \text { MUFA } & 12.7 \pm 1.3 \quad 6.6 \pm 4.2 & 9.2 \pm 6.4\end{array}$

$16: 2 \mathrm{n}-4 \quad 0.2 \pm 0.2 \quad 0 \pm 0 \quad 0.2 \pm 0.4$

$\begin{array}{llll}16: 3 n-4 & 0.6 \pm 0.1 & 0.3 \pm 0.5 & 0.7 \pm 0.6\end{array}$

$16: 3 n-6 \quad 0.4 \pm 0.2 \quad 0.2 \pm 0.3 \quad 0 \pm 0$

$16: 3 n-3 \quad 0.2 \pm 0.1 \quad 0 \pm 0 \quad 0.2 \pm 0.3$

$16: 4 n-3 \quad 0.3 \pm 0.1 \quad 1.3 \pm 1.1 \quad 1.2 \pm 0.1$

$18: 2 \mathrm{n}-6 \quad 4.2 \pm 2.1 \quad 0.9 \pm 0.8 \quad 0.7 \pm 1$

$18: 2 \mathrm{n}-4 \quad 0.2 \pm 0.1 \quad 0.2 \pm 0.4 \quad 0 \pm 0$

$\begin{array}{llll}18: 3 n-6 & 0.2 \pm 0 & 0.1 \pm 0.3 & 0.4 \pm 0.7\end{array}$

$18: 3 n-4 \quad 0.6 \pm 0.1 \quad 1.4 \pm 0.5 \quad 5.9 \pm 1.7$

$\begin{array}{lllll}18: 3 n-3 & 0.7 \pm 0.3 & 0.6 \pm 0.7 & 0.3 \pm 0.5\end{array}$

$\begin{array}{llll}18: 4 n-3 & 1.1 \pm 0.9 & 2.7 \pm 0.3 & 1.2 \pm 0.2\end{array}$

20:2n-6 $\quad 0.6 \pm 0.2 \quad 1.3 \pm 0.2 \quad 0.9 \pm 0.2$

$20: 3 n-6 \quad 0.2 \pm 0 \quad 0.5 \pm 0 \quad 0 \pm 0$

$20: 3 n-3 \quad 0.2 \pm 0 \quad 0.5 \pm 0.9 \quad 0 \pm 0$

$20: 4 n-6 \quad 6.3 \pm 0.9 \quad 0 \pm 0 \quad 0.7 \pm 0.6$

$20: 4 n-3 \quad 0.4 \pm 0.2 \quad 1.6 \pm 0.2 \quad 1.1 \pm 0.2$

$20: 5 n-3 \quad 8.2 \pm 2.1 \quad 2.2 \pm 1.2 \quad 4.6 \pm 1$

21:5n-3 $\quad 0 \pm 0 \quad 0 \pm 0 \quad 0 \pm 0$
$0.1 \pm 0 \quad 0.6 \pm 0.1 \quad 0.7 \pm 0.1$

$0.2 \pm 0.1 \quad 0.4 \pm 0.1 \quad 0.6 \pm 0.1$

$0 \pm 0 \quad 0 \pm 0 \quad 0 \pm 0$

$1 \pm 0.7 \quad 2.5 \pm 0.7 \quad 2.9 \pm 0.2$

$1.1 \pm 0.3 \quad 2.7 \pm 0.5 \quad 5.8 \pm 0.3$

$0.1 \pm 0.1 \quad 0.1 \pm 0.2 \quad 0 \pm 0$

$0.2 \pm 0.1 \quad 3.6 \pm 0.6 \quad 0.5 \pm 0.4$

$0.1 \pm 0 \quad 0 \pm 0 \quad 0.3 \pm 0.3$

$0.1 \pm 0 \quad 0 \pm 0 \quad 0 \pm 0$

$0 \pm 0 \quad 0 \pm 0 \quad 0 \pm 0$

$3.9 \pm 0.5 \quad 16.5 \pm 2.720 .7 \pm 0.6$

$0.2 \pm 0.2 \quad 0.1 \pm 0.1 \quad 0.7 \pm 0.1$

$0.1 \pm 0.1 \quad 1.2 \pm 0.1 \quad 1.3 \pm 0.1$

$0.1 \pm 0.1 \quad 0 \pm 0 \quad 0.3 \pm 0.3$

$0.1 \pm 0.1 \quad 1 \pm 0.1 \quad 1.2 \pm 0.3$

$0.2 \pm 0.2 \quad 1.3 \pm 0.1 \quad 0.7 \pm 0.1$

$\begin{array}{lll}1.9 \pm 0.4 & 1.2 \pm 0.2 & 1.1 \pm 0.2\end{array}$

$0 \pm 0.1 \quad 0.2 \pm 0.2 \quad 0.4 \pm 0.1$

$0.1 \pm 0 \quad 0.3 \pm 0 \quad 0 \pm 0$

$0.1 \pm 0 \quad 1.2 \pm 0.4 \quad 1.6 \pm 0.1$

$0.2 \pm 0.1 \quad 1.3 \pm 0.2 \quad 0.7 \pm 0$

$0.2 \pm 0.1 \quad 3.8 \pm 0.5 \quad 1.6 \pm 0.2$

$\begin{array}{lll}0.1 \pm 0 & 0.1 \pm 0.2 & 0.2 \pm 0.3\end{array}$

$0.1 \pm 0 \quad 0.5 \pm 0 \quad 0.5 \pm 0.1$

$0.1 \pm 0 \quad 0 \pm 0 \quad 0.3 \pm 0.2$

$\begin{array}{lll}1.6 \pm 0.2 & 0.2 \pm 0.2 & 1.5 \pm 0.1\end{array}$

$\begin{array}{llll}0.1 \pm 0 & 0.7 \pm 0 & 0.7 \pm 0.1\end{array}$

$1.4 \pm 0.7 \quad 4.5 \pm 0.6 \quad 6.3 \pm 1.2$

$0 \pm 0 \quad 0 \pm 0 \quad 0 \pm 0$
$0.4 \pm 0 \quad 0.5 \pm 0.4 \quad 0.8 \pm 0.2$ $0.6 \pm 0.3 \quad 0.8 \pm 0.1 \quad 0.3 \pm 0.2$

$0 \pm 0 \quad 0 \pm 0 \quad 0 \pm 0$

$0.9 \pm 0.8 \quad 0 \pm 0 \quad 1.9 \pm 1$

$2.1 \pm 1.3 \quad 0.5 \pm 0.5 \quad 4.2 \pm 1.5$

$0.4 \pm 0 \quad 0 \pm 0 \quad 0.3 \pm 0.2$

$0.5 \pm 0.4 \quad 1.2 \pm 1 \quad 0.6 \pm 0.6$

$0.3 \pm 0.2 \quad 0 \pm 0 \quad 0.4 \pm 0.8$

$0.2 \pm 0.1 \quad 0 \pm 0 \quad 0 \pm 0$

$0 \pm 0 \quad 0 \pm 0 \quad 0 \pm 0$

$8.7 \pm 4.8 \quad 4.3 \pm 2.4 \quad 17 \pm 6.6$

$2.1 \pm 0.7 \quad 0 \pm 0 \quad 0.4 \pm 0.5$

$0 \pm 0 \quad 0 \pm 0 \quad 0 \pm 0$

$0.4 \pm 0.3 \quad 0 \pm 0 \quad 0.2 \pm 0.4$

$0.6 \pm 0.5 \quad 0 \pm 0 \quad 1.2 \pm 0.9$

$0 \pm 0 \quad 0 \pm 0 \quad 0 \pm 0$

$3 \pm 1.8 \quad 0.9 \pm 0.1 \quad 1.2 \pm 0.3$

$0 \pm 0 \quad 0 \pm 0 \quad 0 \pm 0$

$0.3 \pm 0 \quad 0 \pm 0 \quad 0.2 \pm 0.2$

$0.4 \pm 0 \quad 0.8 \pm 0.3 \quad 2.5 \pm 1.7$

$0.5 \pm 0.2 \quad 0.2 \pm 0.3 \quad 0.4 \pm 0.4$

$1 \pm 0.4 \quad 2.5 \pm 0.5 \quad 2.2 \pm 0.6$

$0.3 \pm 0 \quad 0 \pm 0 \quad 0.4 \pm 0.7$

$0.2 \pm 0.1 \quad 0 \pm 0 \quad 0.4 \pm 0.1$

$0 \pm 0 \quad 0 \pm 0 \quad 0 \pm 0$

$2.8 \pm 1.7 \quad 0.2 \pm 0.3 \quad 1.2 \pm 0.4$

$0.8 \pm 0.3 \quad 2.3 \pm 0.5 \quad 0.6 \pm 0.1$

$3.4 \pm 2.5 \quad 0.8 \pm 0.3 \quad 3 \pm 3$

$0 \pm 0 \quad 0 \pm 0 \quad 3 \pm 5.2$
$0.3 \pm 0.1 \quad 0.4 \pm 0.1 \quad 1.2 \pm 0.3$ $0.7 \pm 0.3 \quad 0.8 \pm 0.1 \quad 0.7 \pm 0.2$ $0.1 \pm 0.1 \quad 0 \pm 0 \quad 0.3 \pm 0$

$2.2 \pm 0.9 \quad 0.2 \pm 0.3 \quad 3.1 \pm 1.1$

$2 \pm 0.8 \quad 0.6 \pm 0.7 \quad 6.9 \pm 1.4$

$0.3 \pm 0.2 \quad 0 \pm 0 \quad 0.3 \pm 0.3$

$0.6 \pm 0.3 \quad 0.4 \pm 0.7 \quad 0.8 \pm 0$

$\begin{array}{lll}0.3 \pm 0 & 0.5 \pm 0.4 & 0.1 \pm 0.2\end{array}$

$0.2 \pm 0.1 \quad 0 \pm 0 \quad 0.1 \pm 0.2$

$0 \pm 0 \quad 0 \pm 0 \quad 0 \pm 0$

$10.4 \pm 2.5 \quad 5.2 \pm 1.9 \quad 15.1 \pm 3.8$

$0.9 \pm 1.1 \quad 0.3 \pm 0.3 \quad 0.2 \pm 0.2$

$0.5 \pm 0.1 \quad 0 \pm 0 \quad 1 \pm 0.9$

$0.3 \pm 0.1 \quad 0.1 \pm 0.2 \quad 1.1 \pm 0.2$

$0.4 \pm 0.1 \quad 0.3 \pm 0.3 \quad 0.9 \pm 0.2$

$0 \pm 0 \quad 0 \pm 0 \quad 0 \pm 0$

$2.3 \pm 0.9 \quad 0.9 \pm 0.2 \quad 1.4 \pm 0.3$

$0 \pm 0 \quad 0 \pm 0 \quad 0 \pm 0$

$0.2 \pm 0.2 \quad 0.1 \pm 0.2 \quad 0.4 \pm 0.1$

$0.2 \pm 0 \quad 0.7 \pm 0.3 \quad 0.7 \pm 0.1$

$0.3 \pm 0.2 \quad 0.4 \pm 0.4 \quad 0.7 \pm 0.1$

$0.8 \pm 0.3 \quad 1.9 \pm 0.6 \quad 2.5 \pm 0.5$

$0.4 \pm 0.4 \quad 1.1 \pm 0.2 \quad 1.3 \pm 0.1$

$0.3 \pm 0.2 \quad 0.3 \pm 0.6 \quad 0.4 \pm 0$

$0.2 \pm 0.1 \quad 0 \pm 0 \quad 0.4 \pm 0$

$2 \pm 0.7 \quad 0.1 \pm 0.2 \quad 2.2 \pm 0.4$

$\begin{array}{lll}1.3 \pm 0.5 & 2.2 \pm 0.9 & 0.5 \pm 0.4\end{array}$

$2.2 \pm 0.6 \quad 1.7 \pm 1 \quad 9.7 \pm 2.3$

$2.3 \pm 3.4 \quad 0 \pm 0 \quad 0 \pm 0$
$0.5 \pm 0.4 \quad 0.1 \pm 0.2 \quad 0.8 \pm 0.7$

$0.4 \pm 0.3 \quad 1.2 \pm 0.2 \quad 0.1 \pm 0.3$

$0 \pm 0 \quad 0 \pm 0 \quad 0 \pm 0$

$\begin{array}{lll}1.8 \pm 0.3 & 5.8 \pm 1.4 & 2.3 \pm 0.2\end{array}$ $4.3 \pm 0.6 \quad 3.7 \pm 1 \quad 4.6 \pm 1.1$

$0.6 \pm 0.3 \quad 0 \pm 0 \quad 0 \pm 0$

$0.5 \pm 0.4 \quad 3.6 \pm 0.8 \quad 0.1 \pm 0.3$

$0.3 \pm 0.3 \quad 0 \pm 0 \quad 0 \pm 0$

$0.3 \pm 0.3 \quad 0 \pm 0 \quad 0 \pm 0$

$0 \pm 0 \quad 0 \pm 0 \quad 0 \pm 0$

$17.3 \pm 3.418 .6 \pm 4.317 .5 \pm 4.7$

$0.9 \pm 0.2 \quad 1.5 \pm 0.3 \quad 0.8 \pm 0.7$ $0.5 \pm 0.4 \quad 0.3 \pm 0.3 \quad 0.5 \pm 0.4$ $0.3 \pm 0.3 \quad 0 \pm 0 \quad 0 \pm 0$

$0.1 \pm 0.1 \quad 0.1 \pm 0.2 \quad 0.2 \pm 0.3$

$\begin{array}{llll}0 \pm 0 & 0 \pm 0 & 0 \pm 0\end{array}$

$3.1 \pm 0.6 \quad 2.5 \pm 0.5 \quad 1.3 \pm 0.4$

$0 \pm 0 \quad 0 \pm 0 \quad 0 \pm 0$

$0.2 \pm 0.1 \quad 0.2 \pm 0.3 \quad 0 \pm 0$

$0 \pm 0.1 \quad 0.2 \pm 0.1 \quad 3.2 \pm 0.4$

$0.5 \pm 0.4 \quad 2.8 \pm 0.8 \quad 0.3 \pm 0.5$

$1.1 \pm 0.4 \quad 4.3 \pm 1.2 \quad 0.9 \pm 0.9$

$0.5 \pm 0.4 \quad 1.6 \pm 0.5 \quad 1.3 \pm 0.6$

$0.2 \pm 0.2 \quad 0 \pm 0 \quad 0 \pm 0$

$1.7 \pm 1.5 \quad 0.4 \pm 0.2 \quad 0.2 \pm 0.3$

$5.9 \pm 1.6 \quad 0.2 \pm 0.2 \quad 1.8 \pm 0.7$

$0.2 \pm 0.2 \quad 1.7 \pm 1 \quad 0 \pm 0$

$11.2 \pm 4.4 \quad 6.7 \pm 1.8 \quad 8.5 \pm 3.1$

$0 \pm 0 \quad 0 \pm 0 \quad 0 \pm 0$ 


\begin{tabular}{|c|c|c|c|c|c|c|c|c|c|c|c|c|c|c|c|}
\hline $22: 2 n-6$ & $0.3 \pm 0.1$ & $0.4 \pm 0$ & $0.9 \pm 0.1$ & $0.3 \pm 0$ & $0.9 \pm 0$ & $1.3 \pm 0.2$ & $2.1 \pm 1.5$ & $7.3 \pm 1$ & $2.8 \pm 2$ & $1.5 \pm 0.8$ & $9.1 \pm 3.2$ & $3 \pm 2.5$ & $3 \pm 2.2$ & $2.7 \pm 1.2$ & $2.9 \pm 1.6$ \\
\hline$: 4 n-6$ & $0.6 \pm 0.5$ & $0.5 \pm 0.1$ & $0 \pm 0$ & $0.1 \pm 0$ & $0 \pm 0$ & $0 \pm 0$ & $0 \pm 0$ & $0 \pm 0$ & $0 \pm 0$ & $0 \pm 0$ & $0 \pm 0$ & $0 \pm 0$ & $0 \pm 0$ & $0 \pm 0$ & $0 \pm 0$ \\
\hline $5 n-6$ & $0.7 \pm 0.1$ & $2.1 \pm 1.3$ & $1.7 \pm 0.5$ & $0.1 \pm 0$ & $0.4 \pm 0$ & $0.6 \pm 0.1$ & $1.9 \pm 0.2$ & $4.4 \pm 0.5$ & $2.5 \pm 0.9$ & $1.6 \pm 0.6$ & $2.3 \pm 0.8$ & $0.9 \pm 0.4$ & $1 \pm 1$ & $1.7 \pm 0.7$ & $0.2 \pm 0.3$ \\
\hline$: 5 n-3$ & $0.7 \pm 0.8$ & $0 \pm 0$ & $0 \pm 0$ & $0.1 \pm 0$ & $0.1 \pm 0.2$ & $0 \pm 0$ & $0.7 \pm 0.1$ & $2.1 \pm 0.6$ & $2.1 \pm 1.7$ & $0.6 \pm 0.5$ & $2.2 \pm 0.5$ & $2.3 \pm 0.7$ & $0.5 \pm 0.3$ & $1.3 \pm 1.2$ & $0.6 \pm 0.6$ \\
\hline $6 n-3$ & $4.3 \pm 2.8$ & $0.9 \pm 1.1$ & $0.7 \pm 0.7$ & $0.5 \pm 0.2$ & $2.9 \pm 0.4$ & $1.9 \pm 0.2$ & $1.7 \pm 0.3$ & $4 \pm 0.5$ & $4.5 \pm 0.8$ & $1.5 \pm 2.1$ & $0 \pm 0$ & $3.6 \pm 1.7$ & $3.7 \pm 1.7$ & $6 \pm 1.8$ & $2.9 \pm 1.1$ \\
\hline PUFA & $31.2 \pm 6.5$ & $17.6 \pm 4.7$ & $21.5 \pm 3.2$ & $7.8 \pm 1.6$ & $22 \pm 1.8$ & $22.9 \pm 1.8$ & $22.3 \pm 6.1$ & $25.6 \pm 1.6$ & $28.7 \pm 2.3$ & $19.8 \pm 4.7$ & $23.9 \pm 4.9$ & $33.3 \pm 3.1$ & $34.5 \pm 7$ & $33.9 \pm 4.9$ & $25.6 \pm 5.6$ \\
\hline A & $0.5 \pm 0.4$ & $0 \pm 0$ & $0 \pm 0$ & $0.1 \pm 0$ & $0.1 \pm 0.1$ & $0 \pm 0$ & $0.2 \pm 0$ & $0 \pm 0$ & $0 \pm 0$ & $0.3 \pm 0$ & $0 \pm 0$ & $0 \pm 0$ & $1.2 \pm 1.4$ & $0 \pm 0$ & $0 \pm 0$ \\
\hline M & $0.8 \pm 0.2$ & $0.4 \pm 0$ & $0.2 \pm 0.4$ & $0.2 \pm 0.1$ & $0.4 \pm 0$ & $0 \pm 0$ & $0.5 \pm 0.2$ & $0 \pm 0$ & $0 \pm 0$ & $0.4 \pm 0.2$ & $0 \pm 0$ & $0 \pm 0$ & $0.4 \pm 0.3$ & $0 \pm 0$ & $0 \pm 0$ \\
\hline $\mathrm{N}$ & $0.4 \pm 0.1$ & $0.5 \pm 0$ & $1.4 \pm 1.8$ & $0.2 \pm 0.1$ & $0.5 \pm 0$ & $0.6 \pm 0.1$ & $0.5 \pm 0.2$ & $0 \pm 0$ & $0.1 \pm 0.2$ & $0.4 \pm 0$ & $0.7 \pm 0.6$ & $0.4 \pm 0$ & $0 \pm 0$ & $0 \pm 0$ & $0 \pm 0$ \\
\hline $\mathrm{O}$ & $0.8 \pm 0$ & $5.2 \pm 2.1$ & $5.5 \pm 3.9$ & $0.8 \pm 0.6$ & $3.1 \pm 0.6$ & $0.5 \pm 0.5$ & $0 \pm 0$ & $0 \pm 0$ & $0 \pm 0$ & $0 \pm 0$ & $0 \pm 0$ & $0 \pm 0$ & $1 \pm 0.6$ & $2.2 \pm 1.5$ & $2.7 \pm 2.1$ \\
\hline $\mathrm{P}$ & $1.4 \pm 0$ & $4 \pm 0.6$ & $4.9 \pm 1.1$ & $0.5 \pm 0.2$ & $1.9 \pm 0.1$ & $3.9 \pm 0.5$ & $1.1 \pm 0.5$ & $0.9 \pm 0.8$ & $4.8 \pm 1.3$ & $1.4 \pm 1.5$ & $1.2 \pm 0.3$ & $0.6 \pm 0.6$ & $0.4 \pm 0.3$ & $0.3 \pm 0.3$ & $0.5 \pm 0.5$ \\
\hline $\mathrm{W}$ & $0 \pm 0$ & $0 \pm 0$ & $0 \pm 0$ & $0.1 \pm 0$ & $0.6 \pm 0$ & $0.8 \pm 0.1$ & $0.1 \pm 0.1$ & $0.6 \pm 0$ & $0.5 \pm 0$ & $0.2 \pm 0$ & $0.7 \pm 0.6$ & $0.6 \pm 0.1$ & $0.2 \pm 0.2$ & $0.2 \pm 0.2$ & $0 \pm 0$ \\
\hline JK FA & $4 \pm 0.7$ & $10.1 \pm 1.5$ & $11.9 \pm 5.2$ & $1.7 \pm 1.1$ & $6.5 \pm 0.6$ & $5.8 \pm 1.1$ & $2.4 \pm 0.6$ & $1.5 \pm 0.8$ & $5.4 \pm 1.3$ & $2.6 \pm 1.4$ & $2.6 \pm 1.3$ & $1.6 \pm 0.6$ & $3.2 \pm 1.2$ & $2.7 \pm 1.5$ & $3.2 \pm 1.9$ \\
\hline A/SFA & $0.7 \pm 0.2$ & $0.3 \pm 0.1$ & $0.5 \pm 0.1$ & $0.1 \pm 0$ & $0.4 \pm 0.1$ & $0.6 \pm 0.1$ & $0.4 \pm 0.2$ & $0.4 \pm 0$ & $0.7 \pm 0.2$ & $0.3 \pm 0.1$ & $0.4 \pm 0.1$ & $0.8 \pm 0.1$ & $1 \pm 0.4$ & $0.9 \pm 0.3$ & $0.6 \pm 0.2$ \\
\hline /DHA & $2.3 \pm 1$ & NA & NA & $2.8 \pm 0.5$ & $1.6 \pm 0$ & $3.4 \pm 0.4$ & $1.9 \pm 1.3$ & $0.2 \pm 0.1$ & $0.8 \pm 0.8$ & NA & NA & $3.1 \pm 1.6$ & $3.1 \pm 0.6$ & $1.1 \pm 0$ & $2.9 \pm 0.1$ \\
\hline $3 / \sum n-6$ & $51.2 \pm 0.6$ & $1.7 \pm 0.4$ & $1.8 \pm 0.5$ & $0.7 \pm 0.3$ & $4.4 \pm 0$ & $2.5 \pm 0.4$ & $0.8 \pm 0.2$ & $0.9 \pm 0.1$ & $2.1 \pm 1.1$ & $1.2 \pm 0.4$ & $0.6 \pm 0.1$ & $1.9 \pm 0.4$ & $1.3 \pm 0.3$ & $2.7 \pm 0.7$ & $2 \pm 1.1$ \\
\hline
\end{tabular}


Table S3: Stable isotope (mean $\pm \mathrm{SD}, \mathbf{n}=3$ ) composition of organic matter sources (Biofilm, suspended particulate organic matter (SPOM), superficial sedimentary organic matter (SSOM)) over the sampling survey.

\begin{tabular}{|c|c|c|c|c|c|c|c|c|c|c|c|c|c|c|c|}
\hline & \multicolumn{3}{|c|}{$\mathrm{S} 1=26^{\text {th }}$ February } & \multicolumn{3}{|c|}{$\mathrm{S} 2=21^{\text {th }}$ March } & \multicolumn{3}{|c|}{$\mathrm{S} 3=28^{\text {th }}$ March } & \multicolumn{3}{|c|}{$\mathrm{S} 4=12^{\text {th }}$ April } & \multicolumn{3}{|c|}{ S5 $=14^{\text {th }}$ June } \\
\hline & Biofilm & SPOM & SSOM & ofilm & SPOM & SSOM & Biofilm & SPOM & SSOM & Biofilm & SPOM & SSOM & Biofilm & SPOM & SSOM \\
\hline$\delta^{13} \mathrm{C}$ & $-22.6 \pm 0.1$ & $-25.2 \pm 0.2$ & $-23 \pm 0.2$ & $-23.4 \pm 0.5$ & $-25.3 \pm 0.1$ & $-22.7 \pm 0.3$ & $-22.6 \pm 0.4$ & $-25.3 \pm 0.1$ & $-22.6 \pm 0.1$ & $-23.4 \pm 1-$ & $-24.6 \pm 0.4$ & $-22.5 \pm 0.1$ & $-21.8 \pm 0.2$ & $-25.1 \pm 0.3$ & $-22.5 \pm 0.1$ \\
\hline$\delta^{15} \mathrm{~N}$ & $9.4 \pm 0.6$ & $7.3 \pm 0$ & $7 \pm 0.7$ & $10.3 \pm 0.5$ & $6.7 \pm 0.3$ & $7.1 \pm 0.1$ & $9.2 \pm 0.7$ & $6.6 \pm 0.1$ & $7 \pm 0.1$ & $9.2 \pm 0.7$ & $6.9 \pm 0.9$ & $7.1 \pm 0.1$ & $9.4 \pm 0.7$ & $6.4 \pm 0.5$ & $6.9 \pm 0.2$ \\
\hline $\mathrm{C} / \mathrm{N}$ & $3.9 \pm 0.3$ & $6.6 \pm 1.1$ & $5.1 \pm 1.3$ & $5.8 \pm 3$ & $5.9 \pm 0.6$ & $5.3 \pm 0.6$ & $5.3 \pm 0.4$ & $6 \pm 0.5$ & $5.5 \pm 0.6$ & $5 \pm 0.5$ & $5.6 \pm 0.9$ & $5.4 \pm 0.5$ & $3.6 \pm 0.6$ & $3.9 \pm 0.4$ & $5.9 \pm 0.8$ \\
\hline
\end{tabular}


Table S4: Fatty acid (FA) (\%, mean \pm SD, $\mathbf{n}=5$ ) composition of the three ontogenic stages of Crepidula fornicata (motile males, sessile males, sessile females) over the sampling survey. Only FA accounting for more than $0.5 \%$ of total FA in at least one sample was shown. BFA: Branched FA; SFA: saturated FA; MUFA: monounsaturated FA; PUFA: polyunsaturated FA; NMI FA: non-methyl-interrupted FA; DMA: Dimethyl acetals FA; EPA: 20:5n-3; DHA: 22:6n-3.

\begin{tabular}{|c|c|c|c|c|c|c|c|c|c|c|c|c|c|c|c|}
\hline \multirow[b]{2}{*}{ Fatty acids } & \multicolumn{3}{|c|}{$\mathrm{S} 1=26^{\text {th }}$ February } & \multicolumn{3}{|c|}{$\mathrm{S} 2=21^{\text {th }}$ March } & \multicolumn{3}{|c|}{$\mathrm{S} 3=28^{\text {th }}$ March } & \multicolumn{3}{|c|}{$\mathrm{S} 4=12^{\text {th }}$ April } & \multicolumn{3}{|c|}{$\mathrm{S} 5=14^{\text {th }}$ June } \\
\hline & $\begin{array}{l}\text { Sessile } \\
\text { female }\end{array}$ & $\begin{array}{l}\text { Sessile } \\
\text { male }\end{array}$ & $\begin{array}{c}\text { Motile } \\
\text { male }\end{array}$ & $\begin{array}{l}\text { Sessile } \\
\text { female }\end{array}$ & $\begin{array}{c}\text { Sessile } \\
\text { male }\end{array}$ & $\begin{array}{r}\text { Mot } \\
\text { ma }\end{array}$ & $\begin{array}{l}\text { Sessile } \\
\text { female }\end{array}$ & $\begin{array}{c}\text { Sessile } \\
\text { male }\end{array}$ & $\begin{array}{r}\mathrm{Mo} \\
\mathrm{ma}\end{array}$ & $\begin{array}{l}\text { le } \\
\text { le }\end{array}$ & $\begin{array}{c}\text { Sessile } \\
\text { male }\end{array}$ & $\begin{array}{r}\mathrm{Mc} \\
\mathrm{m} \\
\end{array}$ & $\begin{array}{l}\text { le } \\
\text { le }\end{array}$ & $\begin{array}{c}\text { Sessile } \\
\text { male }\end{array}$ & $\begin{array}{l}\text { otile } \\
\text { nale } \\
\end{array}$ \\
\hline & \pm 0.3 & 1.1 & +06 & \pm 0.2 & & 04 & \pm 0.7 & 0.4 & 12 & +1 & 0.8 & $25+1$ & $.1 \pm 1.7$ & 0.7 & $1 \pm 0.6$ \\
\hline 15: & $0.2 \pm 0$ & 0 & 0 & .1 & & 0 & 0.1 & & & 1 & & & & & \\
\hline 15 & \pm 0 & $0 \pm 0$ & \pm 0 & \pm 0 & $0 \pm 0$ & $0 \pm 0$ & \pm 0.1 & 0 & $0 \pm 0$ & \pm 0.1 & $0 \pm 0$ & $0.3 \pm 0.5$ & $0 \pm 0$ & $.4 \pm 0.3$ & $0.7 \pm 0.1$ \\
\hline 16:0iso & \pm 0.5 & \pm 0.3 & \pm 0.1 & \pm 0.1 & \pm 0.2 & \pm 0.2 & \pm 0.1 & 0.1 & $6 \pm 1$ & \pm 0.2 & $.5 \pm 0.1$ & 0.4 & $.7 \pm 0.2$ & \pm 0 & $=0.2$ \\
\hline $17:$ & $5.4 \pm 1.8$ & $1 \pm 1$ & $3.4 \pm 0.5$ & +18 & $1.7 \pm 2.4$ & $1.1 \pm 1$ & $3.5 \pm 2$ & $2.8 \pm 1.4$ & $2.5 \pm 1.1$ & $3.8 \pm 1$ & $2.4 \pm 0.1$ & $3 \pm 0.3$ & $3 \pm 1$ & $.3 \pm 0.2$ & $1.4 \pm 0.3$ \\
\hline & 5.011 .0 & $3.2-0.1$ & $2.4+0.0$ & -0.0 & & $10-0.0$ & $2.0-0.1$ & & $3 \pm 1$ & $2.1-0.1$ & & 2.010 .0 & & & $1.5 \pm 0.3$ \\
\hline & $0.7 \pm 0.4$ & $0.6 \pm 0.4$ & $0.3 \pm 0.4$ & \pm 0.3 & $0.2 \pm 0.3$ & $0 \pm 0$ & \pm 0.5 & $0.9 \pm 0.2$ & $0.2 \pm 0.4$ & \pm 0.6 & $0.7 \pm 0.1$ & $2.1 \pm 2.9$ & \pm 0.4 & $0.1 \pm 0.1$ & $0 \pm 0$ \\
\hline$\sum$ & $2 \pm 4.3$ & $8.9 \pm 2.1$ & $7.1 \pm 1.3$ & $63+23$ & 6. & $2.8 \pm 1$ & +26 & $78+18$ & $3+2 ?$ & +22 & $6 \pm 0.3$ & $89+4$ & \pm 2.6 & \pm 1 & $5 \pm 0.9$ \\
\hline 14 & $5 \pm 0.3$ & $1.3 \pm 0.7$ & $1.4 \pm 0.4$ & $1.3 \pm 0.2$ & $3 \pm 0.9$ & $1.0 \pm 0.1$ & $.3 \pm 0.4$ & $1.4 \pm 0.3$ & $0.8 \pm 0.8$ & $2 \pm 0.5$ & $2.3 \pm 0.4$ & $1.9 \pm$ & $2.4 \pm 0.6$ & $.7 \pm 0.6$ & $2.2 \pm 0.2$ \\
\hline 15 & $6 \pm 0.1$ & $0.6 \pm 0.2$ & $0.8 \pm 0.2$ & $0.4 \pm 0$ & $0.5 \pm 0.1$ & $0.6 \pm 0.4$ & $0.5 \pm 0.1$ & $0.4 \pm 0$ & $0.1 \pm 0.3$ & $0.5 \pm 0.1$ & $0.5 \pm 0.1$ & $0.6 \pm 0$ & $0.4 \pm 0$ & $0.7 \pm 0.4$ & $1.5 \pm 0.3$ \\
\hline 1 & $9 \pm 0.8$ & $16.7 \pm 3.1$ & $25.2 \pm 3.5$ & $7+1$ & $6 \pm 3.3$ & $7 \pm 1.7$ & 1 & \pm 0.9 & \pm 2.3 & $12 \pm 0.4$ & $.6 \pm 3.1$ & $14.2 \pm 2.1$ & \pm 0.9 & .4 & .9 \\
\hline 17:0 & $1.5 \pm 0.1$ & $1.2 \pm 0.3$ & $1 \pm 0.1$ & $1.4 \pm 0.1$ & \pm 0.1 & $0.7 \pm$ & 0.5 & $0.8 \pm 0.1$ & $0.4 \pm 0.5$ & $0.9 \pm 0.5$ & $0.8 \pm 0.1$ & & $1.1 \pm 0.2$ & 0.1 & $0.7 \pm 0.1$ \\
\hline $18: 0$ & $.3 \pm 0.9$ & $17.7 \pm 7.3$ & $27.5 \pm 4.2$ & $6.8 \pm 0.7$ & $9.2 \pm 3.9$ & $35.6 \pm 0.9$ & $6.6 \pm 0.9$ & $10.4 \pm 1.3$ & $14.8 \pm 4.5$ & $6.9 \pm 0.4$ & $9.1 \pm 5.6$ & $14.3 \pm 3.1$ & $6.9 \pm 1.2$ & $.6 \pm 1.1$ & $7.5 \pm 1.1$ \\
\hline 20:0 & $0.5 \pm 0.1$ & $0.7 \pm 0.2$ & $0.5 \pm 0.3$ & $0.5 \pm 0.3$ & $0.2 \pm 0.2$ & $0.6 \pm 0.3$ & $0.2 \pm 0$ & $0.2 \pm 0.3$ & $0 \pm 0$ & $0.2 \pm 0$ & $0.2 \pm 0.1$ & $0.1 \pm 0.2$ & $0.4 \pm 0.1$ & $0.2 \pm 0.1$ & $0.3 \pm 0$ \\
\hline $22: 0$ & $0.5 \pm 0.1$ & $0.3 \pm 0.2$ & $0.1 \pm 0.2$ & $0.4 \pm 0.1$ & $0.2 \pm 0$ & $0 \pm 0$ & $0.4 \pm 0.1$ & $0.1 \pm 0.1$ & $0 \pm 0$ & $0.3 \pm 0.1$ & $0.2 \pm 0.1$ & -5 & $0.3 \pm 0.1$ & $0 \pm 0$ & $0 \pm 0$ \\
\hline $24: 0$ & $0.4 \pm 0.1$ & $0.6 \pm 0.4$ & $0.6 \pm 0.4$ & $0.2 \pm 0$ & $0.2 \pm 0.1$ & $0.7 \pm 0.2$ & $0.3 \pm 0.2$ & $0.1 \pm 0.1$ & & $0.4 \pm 0.1$ & $0.3 \pm 0.1$ & $1.2 \pm 0.5$ & $0.3 \pm 0.1$ & & $0 \pm 0$ \\
\hline$\sum \mathrm{SFA}$ & $23.2 \pm 1.5$ & $39.2 \pm 9.6$ & $57 \pm 8.2$ & $22.9 \pm 1.5$ & $26 \pm 7.1$ & $73.5 \pm 2.4$ & $21.4 \pm 1.1$ & $26.4 \pm 1.7$ & $30.1 \pm 5.9$ & $23.3 \pm 0.9$ & $25.8 \pm 8.6$ & $33.3 \pm 4.6$ & $23.1 \pm 1.7$ & $19.9 \pm 1.2$ & $19.7 \pm 1.6$ \\
\hline & & & & & & & & & & & & & & & $0 \pm 0$ \\
\hline $16: 1 n-11$ & $0 \pm 0$ & $0 \pm 0$ & $0 \pm 0$ & $0 \pm 0$ & $0 \pm 0$ & $0 \pm 0$ & $0.4 \pm 0.1$ & $0.7 \pm 0.4$ & $0 \pm 0$ & $0.1 \pm 0.1$ & $0.2 \pm 0.1$ & $1.1 \pm 1$ & $0 \pm 0$ & $0.1 \pm 0.1$ & $0.2 \pm 0.1$ \\
\hline $16: 1 n-9$ & $0.7 \pm 0.2$ & $0.5 \pm 0.3$ & $0.3 \pm 0.3$ & $0.7 \pm 0.2$ & $0.1 \pm 0.2$ & $0.1 \pm 0.2$ & $0.5 \pm 0.1$ & $0.7 \pm 0.5$ & $0.4 \pm 1$ & $0.5 \pm 0$ & $0.6 \pm 0.1$ & $0.7 \pm 0.3$ & $0.3 \pm 0$ & $0.5 \pm 0.4$ & $4.1 \pm 2.9$ \\
\hline $16: 1 n-7$ & $1.4 \pm 0.6$ & $0.9 \pm 0.2$ & $0.8 \pm 0.3$ & $1.7 \pm 0.2$ & $1.3 \pm 0.4$ & $0.3 \pm 0.4$ & $1.5 \pm 0.3$ & $1.2 \pm 0.4$ & $2.6 \pm 1.3$ & $2.3 \pm 0.6$ & $2.9 \pm 0.8$ & $2.1 \pm 0.3$ & $3.6 \pm 0.9$ & $5.8 \pm 1.9$ & $6.4 \pm 1.9$ \\
\hline $16: 1 n-5$ & $0.4 \pm 0.4$ & $0 \pm 0$ & $0 \pm 0$ & $0.3 \pm 0.1$ & $0.1 \pm 0.1$ & $0 \pm 0$ & $0.3 \pm 0.1$ & $0.8 \pm 0.4$ & $1.4 \pm 1.4$ & $0.5 \pm 0.2$ & $0.4 \pm 0.2$ & $1.8 \pm 1.2$ & $0.9 \pm 0.4$ & $3.4 \pm 2.1$ & $2.2 \pm 4.3$ \\
\hline
\end{tabular}




\begin{tabular}{|c|c|c|c|c|c|c|c|c|c|c|c|c|c|c|c|}
\hline $17: 1 n-7$ & $0.1 \pm 0.1$ & $0 \pm 0$ & $0 \pm 0$ & $0.1 \pm 0.1$ & $0 \pm 0$ & $0 \pm 0$ & $0.4 \pm 0.5$ & $0.1 \pm 0.3$ & $0 \pm 0$ & $0.3 \pm 0.4$ & $0 \pm 0.1$ & $0.2 \pm 0.3$ & $0 \pm 0$ & $0 \pm 0$ & $0 \pm 0$ \\
\hline $18: 1 n-11$ & $0.5 \pm 0.2$ & $0.4 \pm 0.1$ & $1 \pm 0.3$ & $0.5 \pm 0.1$ & $0.4 \pm 0.1$ & $0 \pm 0$ & $0.5 \pm 0.2$ & $0.9 \pm 0.2$ & $1.6 \pm 1$ & $0.8 \pm 0.2$ & \pm 0.1 & $4 \pm 1$ & \pm 0.2 & .4 & $6 \pm 1$ \\
\hline $18: 1 n-9$ & $0 \pm 0.1$ & $0 \pm 0$ & $5.1 \pm 2.3$ & $2.1 \pm 0.3$ & $2.1 \pm 0.2$ & $4 \pm 0.8$ & $2 \pm 0.2$ & $2.3 \pm 0.1$ & $1.6 \pm 1$ & $2 \pm 0.2$ & $2 \pm 0.1$ & $1.8 \pm 0.4$ & $1.5 \pm 0.2$ & $1.5 \pm 0.2$ & $1.2 \pm 0.2$ \\
\hline $18: 1 n-7$ & $2.6 \pm 0.2$ & $1.8 \pm 0.3$ & $1.4 \pm 0.2$ & $2.8 \pm 0.3$ & $2.1 \pm 0.3$ & $1 \pm 0.1$ & $2.5 \pm 0.2$ & $1.7 \pm 0.3$ & $0.7 \pm 1.1$ & $2.3 \pm 0.3$ & $2.3 \pm 0.5$ & $2 \pm 0.9$ & $3.3 \pm 0.4$ & $4.4 \pm 1$ & $2.6 \pm 0.8$ \\
\hline $18: 1 n-5$ & $0.4 \pm 0$ & $0.2 \pm 0.2$ & $0.1 \pm 0.2$ & $0.4 \pm 0$ & $0.4 \pm 0$ & $0.2 \pm 0.4$ & $0.4 \pm 0$ & $0.2 \pm 0.2$ & $0.3 \pm 0.4$ & $0.3 \pm 0$ & $0.3 \pm 0.1$ & $0.5 \pm 0.3$ & $0.5 \pm 0.1$ & $0.6 \pm 0.1$ & $0.6 \pm 0.1$ \\
\hline $20: 1 n-11$ & $5.8 \pm 0.5$ & $5.3 \pm 0.7$ & $3.2 \pm 0.7$ & $6.1 \pm 0.8$ & $6.4 \pm 0.9$ & $1.9 \pm 0.5$ & $5.6 \pm 0.6$ & $4 \pm 0.9$ & $2.3 \pm 1.5$ & $5.2 \pm 0.9$ & $4.1 \pm 1$ & $2.3 \pm 0.6$ & $5.9 \pm 0.6$ & $4.3 \pm 0.8$ & $2.5 \pm 0.3$ \\
\hline $20: 1 n-9$ & $0.9 \pm 0.1$ & $1 \pm 0.2$ & $0.5 \pm 0.4$ & $0.8 \pm 0$ & $1.2 \pm 0.1$ & $0.1 \pm 0.2$ & $8 \pm 0.2$ & $1 \pm 0.2$ & $0.4 \pm 0.5$ & $0.8 \pm 0.1$ & $0.9 \pm 0.1$ & $0.7 \pm 0.1$ & $0.6 \pm 0.2$ & $0.7 \pm 0.1$ & $.4 \pm 0.1$ \\
\hline $20: 1 n-7$ & $4.7 \pm 0.5$ & $3.9 \pm 0.6$ & $2.4 \pm 0.8$ & $4.6 \pm 0.2$ & $5.2 \pm 0.9$ & $1.3 \pm 0.2$ & $4.6 \pm 0.4$ & $3.5 \pm 0.8$ & $5.9 \pm 4.3$ & $4.2 \pm 0.3$ & $4.2 \pm 1.1$ & $4 \pm 1$ & $5.5 \pm 0.9$ & $5.5 \pm 0.7$ & $5 \pm 0.8$ \\
\hline$\sum$ MUFA & $17.8 \pm 1.1$ & $14 \pm 2.1$ & $13.9 \pm 2.5$ & $20.4 \pm 0.6$ & $19.4 \pm 1.6$ & $8.8 \pm 0.7$ & $19.9 \pm 1$ & $17.2 \pm 1.5$ & $17.2 \pm 1.5$ & $19.9 \pm 0.9$ & $18.8 \pm 2.8$ & $18.9 \pm 2.8$ & $22.9 \pm 1.1$ & $28.7 \pm 1.4$ & $31.3 \pm 0.5$ \\
\hline-7 & $0 \pm 0$ & \pm 0 & \pm 0 & -1.0 & -2. & $1-1$ &  & -0 & 0.0 & -0 & 0.0 &  & $-\infty$ & $0 \pm 0$ & \pm 0 \\
\hline $16: 2 n-4$ & $0.4 \pm 0.5$ & $0.1 \pm 0.1$ & $0 \pm 0$ & $0.2 \pm 0$ & $0.5 \pm 0.4$ & $0.2 \pm 0.5$ & $0.7 \pm 0.3$ & $1 \pm 0.9$ & $0.2 \pm 0.4$ & $0.4 \pm 0.2$ & $0.7 \pm 0.3$ & $0.1 \pm 0.3$ & $0.5 \pm 0.2$ & $0.7 \pm 0.4$ & $0.6 \pm 0.2$ \\
\hline $16: 3 n-4$ & $0.1 \pm 0.1$ & $0 \pm 0$ & $0 \pm 0$ & $0.1 \pm 0.1$ & $0 \pm 0.1$ & $0 \pm 0$ & $0 \pm 0.1$ & $0.1 \pm 0.1$ & $0 \pm 0$ & $0.1 \pm 0.2$ & $0.3 \pm 0.2$ & $0.3 \pm 0.3$ & $0.2 \pm 0.1$ & $0.3 \pm 0.1$ & $0.1 \pm 0.1$ \\
\hline $16: 3 n-6$ & $0.4 \pm 0.3$ & $0.6 \pm 0.2$ & $0.2 \pm 0.3$ & $0.5 \pm 0.1$ & $0.1 \pm 0.2$ & $0 \pm 0$ & $0.1 \pm 0.2$ & $0.1 \pm 0.3$ & $0 \pm 0$ & $0.5 \pm 0.2$ & $0.2 \pm 0.1$ & $0 \pm 0$ & $0.5 \pm 0.2$ & $0 \pm 0$ & $0 \pm 0$ \\
\hline $16: 3 n-3$ & $0.1 \pm 0.1$ & $0 \pm 0$ & $0 \pm 0$ & $0.1 \pm 0.1$ & $0 \pm 0.1$ & $0 \pm 0$ & $0.1 \pm 0.1$ & $0.2 \pm 0.2$ & $0.5 \pm 0.7$ & $0.3 \pm 0.1$ & $0.2 \pm 0.1$ & $1.8 \pm 2.7$ & $1.6 \pm 0.9$ & $0.6 \pm 0.2$ & $0.8 \pm 0.5$ \\
\hline $16: 4 n-3$ & $0.3 \pm 0.2$ & $0.2 \pm 0.2$ & $0 \pm 0$ & $0.3 \pm 0.1$ & $0.6 \pm 0.5$ & $0.1 \pm 0.2$ & $0 \pm 0$ & $0 \pm 0$ & $0 \pm 0$ & $0 \pm 0$ & $0 \pm 0$ & $0 \pm 0$ & $0.2 \pm 0.1$ & $0.4 \pm 0.1$ & $0.6 \pm 0.1$ \\
\hline $18: 2 n-6$ & $1.3 \pm 0.2$ & $1.4 \pm 0.3$ & $1.6 \pm 0.3$ & $1.2 \pm 0.2$ & $0.9 \pm 0.2$ & $0.7 \pm 0.4$ & $1.1 \pm 0.1$ & $1.5 \pm 0.2$ & $0.9 \pm 0.6$ & $1.3 \pm 0.1$ & $1.4 \pm 0.2$ & $1.6 \pm 0.5$ & $0.9 \pm 0.1$ & $3 \pm 1.3$ & $6.3 \pm 1.4$ \\
\hline $18: 2 n-4$ & $0.4 \pm 0.1$ & $0.2 \pm 0.2$ & $0 \pm 0$ & $0.5 \pm 0.1$ & $0.3 \pm 0.1$ & $0 \pm 0$ & $0.5 \pm 0$ & $0.4 \pm 0$ & $0 \pm 0$ & $0.4 \pm 0.1$ & $0.3 \pm 0.1$ & $0 \pm 0$ & $0.8 \pm 0.2$ & $0.7 \pm 0.2$ & $0.4 \pm 0.3$ \\
\hline $18: 3 n-6$ & $0.1 \pm 0$ & $0 \pm 0$ & $0 \pm 0$ & $0.1 \pm 0$ & $0.1 \pm 0.2$ & $0 \pm 0$ & $0.2 \pm 0$ & $0 \pm 0.1$ & $0 \pm 0$ & $0.1 \pm 0.1$ & $0.1 \pm 0.1$ & $0 \pm 0$ & $0.3 \pm 0.2$ & $0.2 \pm 0.1$ & $0.2 \pm 0.3$ \\
\hline $18: 3 n-4$ & $1 \pm 0.5$ & $2.7 \pm 1.2$ & $3.1 \pm 1.7$ & $0.4 \pm 0.3$ & $0.4 \pm 0.5$ & $0 \pm 0$ & $1.1 \pm 0.3$ & $3.5 \pm 1.4$ & $1.3 \pm 1.3$ & $1 \pm 0.4$ & $0.6 \pm 0.3$ & $2.4 \pm 0.8$ & $0.3 \pm 0.1$ & $0.3 \pm 0$ & $0 \pm 0$ \\
\hline $18: 3 n-3$ & $0.9 \pm 0.2$ & $0.2 \pm 0.2$ & $0 \pm 0$ & $0.9 \pm 0.2$ & $1 \pm 0.8$ & $1.7 \pm 1$ & $0.9 \pm 0.1$ & $1.2 \pm 0.3$ & $2.1 \pm 3.3$ & $1.1 \pm 0.2$ & $1.6 \pm 0.4$ & $0.7 \pm 0.4$ & $0.5 \pm 0.1$ & $0.9 \pm 0.2$ & $0.5 \pm 0.2$ \\
\hline $18: 4 n-3$ & $0.7 \pm 0.6$ & $0 \pm 0$ & $0.6 \pm 0.6$ & $1.8 \pm 0.4$ & $1.4 \pm 0.5$ & $2.3 \pm 0.2$ & $1.7 \pm 0.3$ & $3 \pm 0.6$ & $2.9 \pm 0.7$ & $3.1 \pm 1$ & $4.4 \pm 0.8$ & $3.2 \pm 0.8$ & $2.7 \pm 0.5$ & $2 \pm 0.3$ & $1.5 \pm 0.2$ \\
\hline $18: 4 n-1$ & $0.1 \pm 0$ & $0 \pm 0$ & $0 \pm 0$ & $0.1 \pm 0.1$ & $0.1 \pm 0.1$ & $0 \pm 0$ & $0 \pm 0.1$ & $0 \pm 0$ & $0.4 \pm 1$ & $0 \pm 0$ & $0 \pm 0$ & $0 \pm 0$ & $0.1 \pm 0.1$ & $0.1 \pm 0.1$ & $0 \pm 0$ \\
\hline $20: 2 n-6$ & $1.2 \pm 0.1$ & $2.2 \pm 0.5$ & $1.1 \pm 0.2$ & $1.2 \pm 0.2$ & $2.1 \pm 0.6$ & $0.9 \pm 0.2$ & $1.1 \pm 0.2$ & $1.1 \pm 0.2$ & $0.4 \pm 0.5$ & $1 \pm 0.2$ & $1 \pm 0.1$ & $0.5 \pm 0.4$ & $0.9 \pm 0.1$ & $0.6 \pm 0.1$ & $0.4 \pm 0$ \\
\hline $20: 3$ & $0.1 \pm 0$ & $0 \pm 0$ & $0 \pm 0$ & $0.1 \pm 0.1$ & $0 \pm 0.1$ & $0 \pm 0$ & $0.2 \pm 0.1$ & $0 \pm 0$ & $0.3 \pm 0.6$ & $0.1 \pm 0.1$ & $0 \pm 0.1$ & $0.1 \pm 0.3$ & $0.2 \pm 0.1$ & $0.1 \pm 0.1$ & $0.1 \pm 0.1$ \\
\hline $20: 3 n-3$ & $0.4 \pm 0.1$ & $0.1 \pm 0.1$ & $0 \pm 0$ & $0.4 \pm 0.1$ & $0.2 \pm 0.1$ & $0 \pm 0$ & $0.4 \pm 0.1$ & $0.3 \pm 0.3$ & $0 \pm 0$ & $0.4 \pm 0.1$ & $0.4 \pm 0.1$ & $0 \pm 0$ & $0.3 \pm 0.1$ & $0.2 \pm 0$ & $0.1 \pm 0.1$ \\
\hline $20: 4 n-6$ & $2.7 \pm 0.3$ & $3.5 \pm 0.5$ & $2.3 \pm 0.6$ & $2.7 \pm 0.4$ & $3.5 \pm 0.3$ & $1.2 \pm 0.1$ & $2.6 \pm 0.6$ & $2.6 \pm 0.5$ & $0.8 \pm 1.2$ & $2.5 \pm 0.4$ & $1.7 \pm 0.4$ & $1.4 \pm 0.4$ & $1.7 \pm 0.2$ & $1.2 \pm 0.1$ & $0.7 \pm 0.1$ \\
\hline $20: 4 n-3$ & $0.6 \pm 0.1$ & $0.3 \pm 0.2$ & $0.3 \pm 0.3$ & $0.6 \pm 0.2$ & $0.4 \pm 0.1$ & $0 \pm 0$ & $0.5 \pm 0.1$ & $0.6 \pm 0.1$ & $0.5 \pm 0.8$ & $0.6 \pm 0.1$ & $0.8 \pm 0.2$ & $0.3 \pm 0.3$ & $0.4 \pm 0.1$ & $0.5 \pm 0.1$ & $0.4 \pm 0.1$ \\
\hline $20: 5 n-3$ & $10.5 \pm 2.6$ & $5.7 \pm 1.2$ & $3.3 \pm 0.7$ & $12.1 \pm 1.3$ & $8.3 \pm 1.3$ & $2.5 \pm 0.5$ & $11.1 \pm 1.8$ & $6.9 \pm 0.9$ & $3.4 \pm 1.7$ & $11.4 \pm 1.8$ & $11.1 \pm 2.6$ & $5.8 \pm 1.9$ & $14.6 \pm 2.4$ & $16.3 \pm 3.4$ & $9.4 \pm 2.1$ \\
\hline $21: 5 n-3$ & $0.4 \pm 0$ & $0.3 \pm 0.2$ & $0.1 \pm 0.3$ & $0.5 \pm 0.1$ & $0.6 \pm 0.1$ & $0 \pm 0$ & $1.5 \pm 0.6$ & $0.7 \pm 0.2$ & $0 \pm 0$ & $0.5 \pm 0.1$ & $0.8 \pm 0.2$ & $0.1 \pm 0.2$ & $0.9 \pm 0.2$ & $0.8 \pm 0.1$ & $0.5 \pm 0.1$ \\
\hline
\end{tabular}




\begin{tabular}{|c|c|c|c|c|c|c|c|c|c|c|c|c|c|c|c|}
\hline $22: 2 n-6$ & $0.2 \pm 0$ & $0 \pm 0$ & \pm 0 & $0 \pm 0$ & $0 \pm 0$ & $4 \pm 0.1$ & \pm 0.3 & \pm 0 & $0 \pm 0$ & $=0.1$ & \pm 0.1 & $=0$ & \pm 0.1 & \pm 0 & \pm 0.2 \\
\hline $22: 4 n-6$ & $0.6 \pm 0.2$ & $4 \pm 0.1$ & $1 \pm 0.2$ & $0.5 \pm 0.3$ & $0.4 \pm 0.1$ & $0 \pm 0$ & $0.6 \pm 0.1$ & $0.2 \pm 0.2$ & $0 \pm 0$ & $0.6 \pm 0.2$ & $0.2 \pm 0.1$ & $.4 \pm 0.4$ & $0.3 \pm 0.1$ & $2 \pm 0$ & \pm 0.1 \\
\hline $2: 5 n-6$ & $4 \pm 0.1$ & $3 \pm 0.2$ & $1 \pm 0.2$ & $0.5 \pm 0.1$ & $4 \pm 0.1$ & \pm 0 & - & $4 \pm 0.4$ & $5 \pm 1$ & \pm 0.1 & + \pm 0.1 & \pm 0.3 & 1 & \pm 0 & 0.1 \\
\hline 3 & $2 \pm 0.5$ & $1.2 \pm 0.3$ & $0.5 \pm 0.5$ & $2.4 \pm 0.3$ & $1.2 \pm 0.2$ & \pm 0.9 & $2 \pm 1.3$ & $1.4 \pm 0.4$ & $1 \pm 2.2$ & $2 \pm 0.5$ & \pm 2.2 & $2.8 \pm 1.8$ & $6 \pm 0.3$ & \pm 0.1 & $9 \pm 0.1$ \\
\hline $22: 6 n-3$ & $9.7 \pm 2.1$ & $4.9 \pm 0.9$ & $2.6 \pm 0.5$ & $1.1 \pm 1.4$ & $6 \pm 0.6$ & $1.9 \pm 0.5$ & $0.3 \pm 1.6$ & $7 \pm 0.7$ & $4.5 \pm 2.4$ & $4 \pm 2$ & $7.8 \pm 1.5$ & $5.4 \pm 1.5$ & $1 \pm 1.4$ & $.3 \pm 0.7$ & $.3 \pm 0.3$ \\
\hline$\Delta$ & $34.7 \pm 5.1$ & $24.5 \pm 4.5$ & $15.7 \pm 2.5$ & $38.8 \pm 4.6$ & $31.1 \pm 2.5$ & $13 \pm 1.8$ & $38.4 \pm 3.5$ & $32.4 \pm 2$ & & $37.9 \pm 3.4$ & $37.3 \pm 3.7$ & $29 \pm 4.2$ & \pm 2.9 & $=2.3$ & \pm 2.6 \\
\hline $20: 2 \mathrm{i}$ & $1 \pm 0.3$ & $1.1 \pm 0.2$ & $0.7 \pm 0.5$ & $0.9 \pm 0.2$ & $.6 \pm 0.6$ & $0 \pm 0$ & $0.9 \pm 0.2$ & $0.8 \pm 0.3$ & $1.4 \pm 2.8$ & $0.9 \pm 0.2$ & $1 \pm 0.3$ & $0.1 \pm 0.3$ & $.1 \pm 0.1$ & $.3 \pm 0.5$ & $0.8 \pm 0.2$ \\
\hline $20: 2 j$ & $0.5 \pm 0.1$ & $0.4 \pm 0.1$ & $0.2 \pm 0.2$ & $0.4 \pm 0$ & $0.6 \pm 0.1$ & $0 \pm 0$ & $0.4 \pm 0.1$ & $0.3 \pm 0.3$ & $0.2=$ & $0.3 \pm 0.1$ & $0.4 \pm 0.1$ & 0 & $0.4 \pm 0.1$ & $0.4 \pm 0.1$ & \pm 0.1 \\
\hline $22:$ & $9 \pm 0.3$ & 5 & $1.3 \pm 0.7$ & $0 \pm$ & $.8 \pm 1.5$ & .2 &  & $1.9 \pm 0.6$ & $.3 \pm 0.6$ & 0.3 & $1.7 \pm 0.8$ & $0.8 \pm 0.3$ & 0.1 & $.7 \pm 0.2$ & 0.2 \\
\hline $22: 2 j$ & $5.4 \pm 0.8$ & $6 \pm 0.6$ & $3.2 \pm 2$ & $5.1 \pm 1.1$ & $8.7 \pm 3.2$ & $1.4 \pm 0.3$ & $4.2 \pm 0.7$ & $4.4 \pm 1.4$ & $1.8 \pm 1.7$ & $4.6 \pm 0.8$ & $4.5 \pm 1.9$ & $2 \pm 0.7$ & $5.3 \pm 1$ & $3.6 \pm 0.6$ & $1.7 \pm 0.9$ \\
\hline $22: 3 \mathrm{i}$ & \pm 0.2 & $1.1 \pm 0.3$ & 0. & $0.5 \pm$ & $1.4 \pm 0.6$ & 0 & 2 & $0 \pm 0$ & 0 & 1 & 0.3 & 0 & +0 & +0 & +0 \\
\hline FA & $.4 \pm 1.4$ & $11.3 \pm 1.2$ & $5.4 \pm 3.3$ & $=1.8$ & $16 \pm 5.6$ & 0.3 & $7.8 \pm 1.3$ & $7.3 \pm 2.4$ & $3.7=$ & $7.8 \pm 1.4$ & \pm 3.1 & $3 \pm 1.1$ & 1.2 & $6 \pm 0.5$ & \pm 1 \\
\hline 16:0DMA & $0.1 \pm 0$ & $0.0 \pm 0.2$ & $0-0$ & $0 \pm 0$ & $0.1-0.1$ & & $0.2-0.2$ & $0.4 \pm 0.2$ & $0.1-0.0$ & $0.0-0.2$ & $0.5 \pm 0.2$ & $1.8 \pm 2.1$ & $0 . J \pm 0.4$ & $3.2 \pm 2.3$ & $7.6 \pm 1.9$ \\
\hline 18:0DMA & $1 \pm 0.5$ & $0 \pm 0$ & $0 \pm 0$ & $1.2 \pm 0.4$ & $0.1 \pm 0.1$ & $0 \pm 0$ & $1.7 \pm 1$ & $4 \pm 1.9$ & $13.5 \pm 5.8$ & $0.8 \pm 0.4$ & $0.8 \pm 0.6$ & $2.7 \pm 2$ & $0.5 \pm 0.1$ & \pm 0.6 & $4.9 \pm 1.1$ \\
\hline :1n-7DMA & $0.6 \pm 0.3$ & $0 \pm 0$ & $0 \pm 0$ & $0 \pm 0$ & $0 \pm 0$ & $0 \pm 0$ & $1.2 \pm 0.5$ & $1.8 \pm 1$ & $7.1 \pm 3$ & $0.2 \pm 0.1$ & $0.2 \pm 0.2$ & $1.5 \pm 0.8$ & $0 \pm 0$ & $0.1 \pm 0.1$ & $1.2 \pm 0.2$ \\
\hline$\sum$ DMA FA & $7 \pm 0.7$ & $0.3 \pm 0.2$ & $0 \pm 0$ & $1.3 \pm 0.5$ & $0.2 \pm 0.1$ & $0 \pm 0$ & $3.1 \pm 1.4$ & $6.2 \pm 3$ & $20.9 \pm 8.9$ & $1.5 \pm 0.7$ & $1.4 \pm 1$ & $6 \pm 1.8$ & \pm 0.5 & $4.9 \pm 2.9$ & $13.7 \pm 3$ \\
\hline A & $0.3 \pm 0.1$ & $0.2 \pm 0.2$ & $0.1 \pm 0.2$ & \pm 0 & $0.4 \pm 0.1$ & $0 \pm 0$ & $2 \pm 0$ & $0.5 \pm 0.4$ & $0 \pm 0$ & $0.2 \pm 0.1$ & $0.3 \pm 0.1$ & .2 & $0.1 \pm 0.1$ & $0 \pm 0$ & $0 \pm 0$ \\
\hline B & $0.2 \pm 0$ & $0 \pm 0$ & $0 \pm 0$ & $0.2 \pm 0$ & $0.1 \pm 0.1$ & $0 \pm 0$ & $0.1 \pm 0.1$ & $0 \pm 0$ & $0.2 \pm 0.3$ & $0 \pm 0.1$ & $0.1 \pm 0.1$ & $0.2 \pm 0.4$ & $0.1 \pm 0$ & $0 \pm 0$ & $0 \pm 0$ \\
\hline W & $0.3 \pm 0.1$ & $0.6 \pm 0.1$ & $0.1 \pm 0.3$ & $0.3 \pm 0.1$ & $0.7 \pm 0.2$ & $0 \pm 0$ & $0.2 \pm 0.2$ & $0.4 \pm 0.2$ & $0 \pm 0$ & $0.3 \pm 0.1$ & $0.3 \pm 0.1$ & $0.1 \pm 0.2$ & $0.2 \pm 0$ & $0.2 \pm 0$ & $0.1 \pm 0.1$ \\
\hline$\sum \mathrm{UK} F A$ & $0.8 \pm 0.1$ & $0.8 \pm 0.2$ & $0.2 \pm 0.4$ & $0.6 \pm 0.1$ & $1.1 \pm 0.3$ & $0 \pm 0$ & $0.5 \pm 0.2$ & $0.7 \pm 0.6$ & $0.2 \pm 0.3$ & $0.5 \pm 0.1$ & $0.6 \pm 0.1$ & $0.4 \pm 0.4$ & $0.3 \pm 0.1$ & $0.2 \pm 0.1$ & $0.1 \pm 0.1$ \\
\hline PUFA/SFA & $1.5 \pm 0.3$ & $0.7 \pm 0.2$ & $0.3 \pm 0.1$ & $1.7 \pm 0.3$ & $1.3 \pm 0.3$ & $0.2 \pm 0$ & $1.8 \pm 0.2$ & $1.2 \pm 0.1$ & $0.8 \pm 0.5$ & $1.6 \pm 0.2$ & $1.6 \pm 0.6$ & $0.9 \pm 0.2$ & $1.6 \pm 0.2$ & $1.9 \pm 0.2$ & $1.7 \pm 0.2$ \\
\hline EPA/DHA & $1.1 \pm 0.1$ & $1.2 \pm 0.2$ & $1.3 \pm 0.1$ & $1.1 \pm 0.1$ & $1.4 \pm 0.2$ & $1.3 \pm 0.1$ & $1.1 \pm 0.1$ & $1 \pm 0.2$ & $0.8 \pm 0.3$ & $1.2 \pm 0.2$ & $1.4 \pm 0.1$ & $1.1 \pm 0.2$ & $2.5 \pm 0.5$ & $3.8 \pm 0.3$ & $4 \pm 0.6$ \\
\hline$n-3 / \sum n-6$ & $3.7 \pm 1$ & $1.5 \pm 0.1$ & $1.4 \pm 0.4$ & $4.5 \pm 0.6$ & $2.6 \pm 0.5$ & $2.8 \pm 0.7$ & $4.5 \pm 0.5$ & $3.6 \pm 0.3$ & $\operatorname{Inf} \pm \mathrm{NA}$ & $4.6 \pm 0.9$ & $5.9 \pm 0.4$ & $5.5 \pm 2.8$ & $5.6 \pm 1.1$ & $5.3 \pm 1.9$ & $2.2 \pm 0.5$ \\
\hline
\end{tabular}


Table S5: Stable isotope (mean $\pm \mathrm{SD}, \mathrm{n}=5$ ) composition of the three ontogenic stages of Crepidula fornicata (motile males, sessile males, sessile females) over the sampling survey.

\begin{tabular}{|c|c|c|c|c|c|c|c|c|c|c|c|c|c|c|c|}
\hline & \multicolumn{3}{|c|}{$\mathrm{S} 1=26^{\text {th }}$ February } & \multicolumn{3}{|c|}{$\mathrm{S} 2=21^{\text {th }}$ March } & \multicolumn{3}{|c|}{$\mathrm{S} 3=28^{\text {th }}$ March } & \multicolumn{3}{|c|}{$\mathrm{S} 4=12^{\text {th }}$ April } & \multicolumn{3}{|c|}{$\mathrm{S} 5=14^{\text {th }}$ June } \\
\hline & $\begin{array}{l}\text { Sessile } \\
\text { female }\end{array}$ & $\begin{array}{l}\text { Sessile } \\
\text { male }\end{array}$ & $\begin{array}{l}\text { Motile } \\
\text { male }\end{array}$ & $\begin{array}{l}\text { Sessile } \\
\text { female }\end{array}$ & $\begin{array}{l}\text { Sessile } \\
\text { male }\end{array}$ & $\begin{array}{l}\text { Motile } \\
\text { male }\end{array}$ & $\begin{array}{l}\text { Sessile } \\
\text { female }\end{array}$ & $\begin{array}{l}\text { Sessile } \\
\text { male }\end{array}$ & $\begin{array}{l}\text { Motile } \\
\text { male }\end{array}$ & $\begin{array}{l}\text { Sessile } \\
\text { female }\end{array}$ & $\begin{array}{c}\text { Sessile } \\
\text { male }\end{array}$ & $\begin{array}{l}\text { Motile } \\
\text { male }\end{array}$ & $\begin{array}{l}\text { Sessile } \\
\text { female }\end{array}$ & $\begin{array}{l}\text { Sessile } \\
\text { male }\end{array}$ & $\begin{array}{l}\text { Motile } \\
\text { male }\end{array}$ \\
\hline & $-19.5 \pm 0.3$ & $19.4 \pm 0.4$ & $19.4 \pm 0.5$ & $-19.8 \pm 0.3-$ & $19.7 \pm 0.3$ & $-20.1 \pm 0.5$ & $-19.2 \pm 0.6$ & $6 \pm 0$ & $9.9 \pm 0.3$ & $-20.1 \pm 0.4$ & $3 \pm 0.8$ & $.6 \pm 0.5$ & $-18.1 \pm 0.3$ & 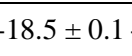 & $8.5 \pm 0.3$ \\
\hline$\delta^{15} \mathrm{~N}$ & $9.3 \pm 0.4$ & $8.9 \pm 0.8$ & $8.9 \pm 0.3$ & $9.6 \pm 0.5$ & $8.9 \pm 0.5$ & $8.4 \pm 1.1$ & $9.7 \pm 0.3$ & $9.4 \pm 0.6$ & $8.5 \pm 0.4$ & $8.4 \pm 0.7$ & $8.4 \pm 0.6$ & $8.3 \pm 0.5$ & $8.6 \pm 0.6$ & $8.3 \pm 0.5$ & $7.5 \pm 0.3$ \\
\hline$/ \mathrm{N}$ & $4 \pm 0.3$ & $3.8 \pm 0.8$ & $4 \pm 0.2$ & $3.2 \pm 0.8$ & $3.8 \pm 0.6$ & $3.5 \pm 0.7$ & $3.6 \pm 0.4$ & $3.3 \pm 0.4$ & $3.8 \pm 0.2$ & $3.6 \pm 0.4$ & $4.3 \pm 0.2$ & $3.8 \pm 0.2$ & $3.5 \pm 0.6$ & $4.1 \pm 1.2$ & $3.4 \pm 0.3$ \\
\hline
\end{tabular}



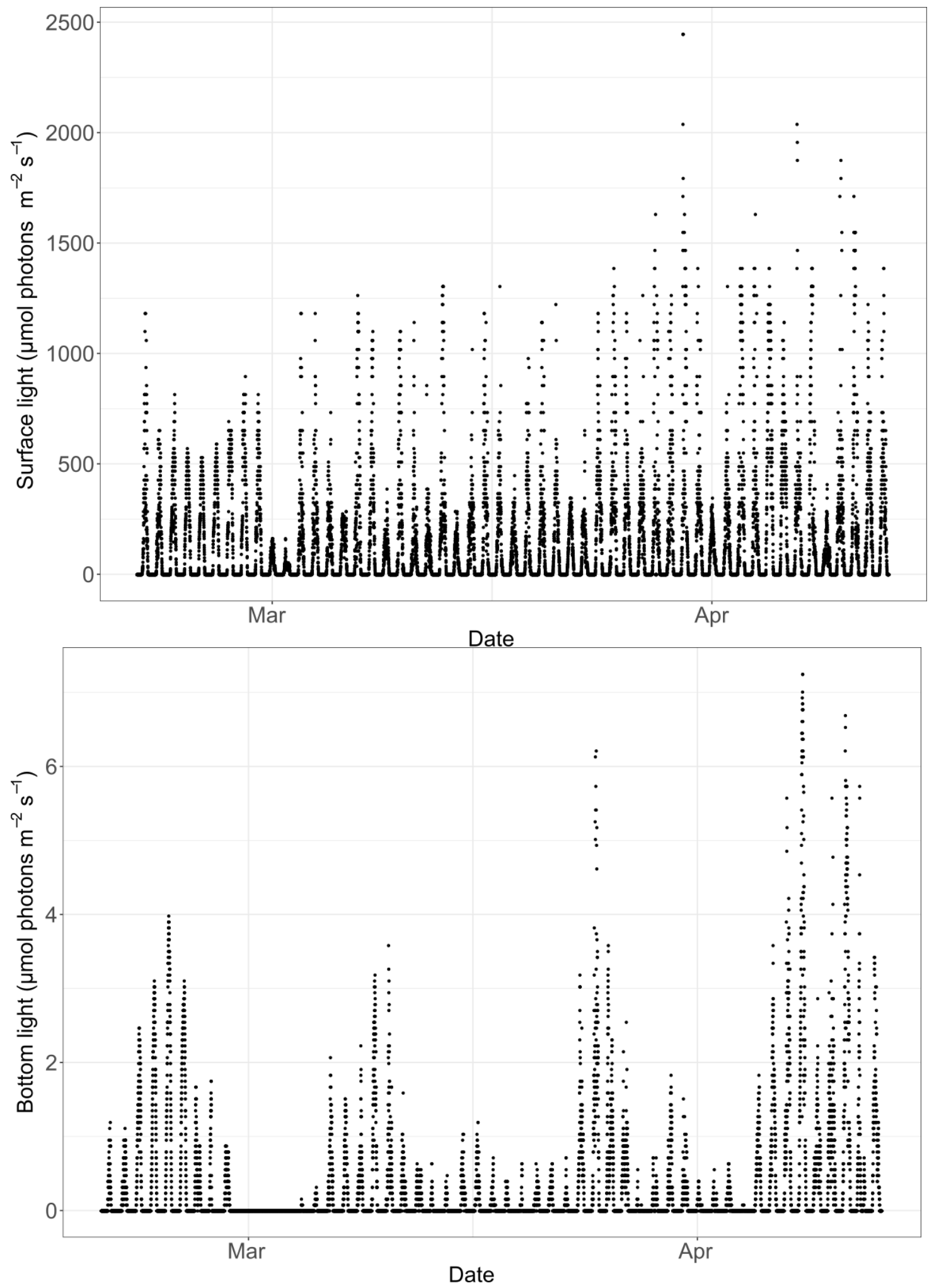
bioRxiv preprint doi: https://doi.org/10.1101/2020.07.30.229021; this version posted July 31, 2020. The copyright holder for this preprint (which was not certified by peer review) is the author/funder. All rights reserved. No reuse allowed without permission.

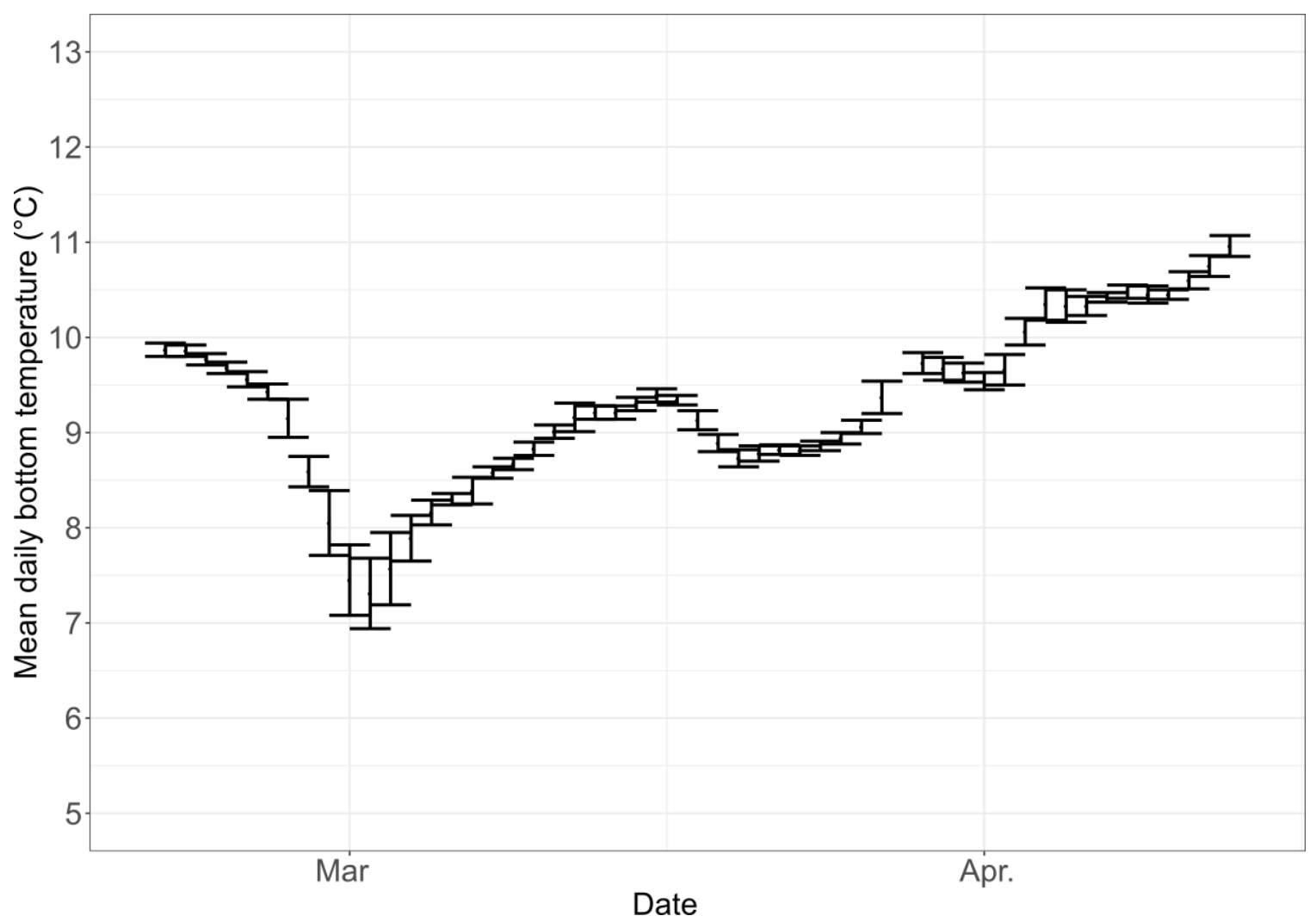

Figure S2: Mean daily temperature $( \pm S D)$ at the bottom in our study site 